\title{
Barry Crump: a bibliography
}

Rowan Gibbs

This bibliography aims to list everything by Barry Crump and most things about him. As well as my own collection of books, periodicals and newspaper clippings on New Zealand literature I have enjoyed access to the resources of the National Library of New Zealand, the Alexander Turnbull Library, the Parliamentary Library, and Wellington City Library, and I have sneaked into Victoria University Library. These have been supplemented by other reference sources, notably the online University of Auckland Library 'New Zealand Literature File', Index New Zealand, the New Zealand Biographies file at National Library, the Electric Library Australasia, and Te Puna and other online library databases and catalogues. I have also had personal communications from librarians and others in New Zealand and overseas. I have not made contact with Crump's close associates nor with his biographer Colin Hogg, whose $A$ Life in Loose Strides ( $\underline{\mathrm{H} 313}$ below) has been of great assistance, despite the frustration of its dearth of references to sources.

I have made an effort to sight all the material here; however a few items taken from reliable sources but unseen are noted as such. All editions and impressions of Crump's books have been recorded, together with the reappearance in omnibus and collected editions of books, sections of books, and stories. But Crump was not only a great reprinter, he was a frequent and effective recycler of his own material, sometimes shuffling the original order or incorporating his short stories into his novels. To help identify such recycling, titles of chapters (which are often self-contained sketches) in the novels are given here in addition to titles of short stories. Instances of reworking that I have detected are noted; others undoubtedly remain to be found.

Page references where given are to first editions.

Reprints of extracts and stories from Crump's books in anthologies are recorded where these have been traced. These are predominantly in collections of humorous or outdoor material; he has seldom been included in collections of New Zealand short stories. Notice of Crump in works on New Zealand literature is uncommon enough to encourage me to ferret out as many examples as possible, sometimes with a brief quotation.

Section A lists short stories and articles by Crump published in periodicals, but interviews and other articles quoting him are in Section $\mathrm{H}$.

In Section B a full lined off transcription is given of the title-page of the first edition of each book with publication details quoted from elsewhere in the book

Kōtare 4, no. 2 (2001), pp. 3-160. 
or from an external source. The level of bibliographic detail here is intended to be adequate to discriminate one printing from another. Variant bindings are noted where these have been seen. The colour of dust-jackets and paperback wrappers is given where one colour is predominant on the front cover. This is followed by briefer entries for later printings, followed by Braille editions, sound recordings, translations, and film and stage adaptations. Details of the number of copies printed and sold are taken in most cases from statements by Crump and are not substantiated. Reprinted extracts are listed with the book they derive from, first extracts recycled by Crump in his own later books then those reprinted elsewhere.

Section C lists books with a specially written contribution by Crump as opposed to extracts garnered from his previously published work. Extracts from his unpublished final book are included in Tribute and in Hogg Loose Strides.

Section D lists film and stage adaptations of his books (film and stage material about him is in $\underline{\mathrm{H}}$ ), Section $\mathrm{E}$ lists music recordings by Crump, Section F films Crump appeared in.

Reviews are listed separately in Section G for convenience of access, though reviewers of Crump's books often take the chance to reminisce about his life and foibles and many reviews include interesting biographical snippets ("The one time I met him..."; Russell Smith, who played Crump on stage, reckoned "one in fifty Kiwis_would have met Crump". For the record I encountered him briefly once, in the sixties, but the motivation for compiling this bibliography was solely as a part of a larger bibliographical project on New Zealand fiction).

Section $\mathrm{H}$ includes in one sequence all secondary material referring in some way to Crump, both his writings and his life, as the two are merged inextricably. This, "Crump: the Critical Heritage", comprises books, articles, interviews and creative writing - drama, fiction, poetry and parody - entirely or partly about him, printed, broadcast, and online. Reviews of books and comments on people included here are noted only if the review or comments refer to Crump himself.

Three Appendices cover (I) Manuscript holdings of Crump material, (J) his Publishers, and $(\mathrm{K})$ his part in Dr Erich Geiringer's cervical smear campaign.

The order within each section is chronological, though in $\underline{H}$ it seemed preferable to keep related material on certain topics together.

The index attempts to bring together items relating to each of Crump's books, stories, articles and poems, together with his illustrators and publishers. It lists also selected authors of secondary material and selected topics and persons mentioned.

Kōtare 4, no. 2 (2001), pp. 3-160. 


\section{Acknowledgments}

I would like to thank the following for responding to queries large and small. The information supplied has been gratefully incorporated but none, of course, are in any way to blame for the way it has been used.

Geoff Adams, John Allan, Ray Bailey, Geraldine \& Gerhard Baumann, Bob Brockie, Virginia Callanan and Siobhan Garrett (NZ Film Archive), Zyg Frankel, Penelope Griffith, George Griffiths, E. Ianakieva (St. Cyrill and St. Methodius National Library of Bulgaria), Ian Jackson, Kevin Jones, Donald Kerr, Peter Kitchin, Max Lambert, Roger Lawrence, Rachel Lord (Radio NZ Sound Archive), John Macalister, Wendy Nasmith (Royal New Zealand Foundation for the Blind), Con O'Leary, Michael O'Leary, Terry O'Neill, John Quilter, Dr Carol Shand, Iain Sharp, Cynthia Shaw (News Media Auckland Library), Dave Smith, TV3, Steven Whitehouse, Sally Williamson (New_Zealand Television Archive), Niel Wright, and the staff of the Manuscripts and Reference Sections of the Hocken and Alexander Turnbull Libraries.

Despite much generous help there will inevitably still be omissions: any additions (and corrections) would be welcomed. Correspondence may be directed to Rowan Gibbs, P O Box 10265, Wellington, New Zealand.

\section{Abbreviations}

- ATL - Alexander Turnbull Library, National Library of New Zealand, Wellington.

- Hogg Loose Strides - Colin Hogg. A Life in Loose Strides, The Story of Barry Crump. Auckland: Hodder Moa Beckett, 2000 (ㅂ13).

- Tribute - Barry Crump: A Tribute to Crumpy, 1935-1996. Auckland: Hodder Moa Beckett, 1996 (느252).

- Crump titles referred to in abbreviated form, Bedtime Yarns, Forty Yarns, Life and Times, are I hope self-explanatory.

\section{A. Original Work by Crump in Periodicals}

A1. 'A good keen man.' Mate 2 (Nov. 1958): 21-5.

Sketch, reworked as 'I meet Legs' in A Good Keen Man; told in the first person.

"... Among my new friends were a bunch of young blokes who were starting up a literary magazine called Mate. It was one of them, Kevin, who talked me into having a go at writing a short story, and they published it...": Life and Times p.63; Kevin Ireland Tribute p.66 talks of writing this first story "together"; see also Ireland's eulogy at Crump's wake (quoted in 'Barry Crump: an unforgettable man'

Kōtare 4, no. 2 (2001), pp. 3-160. 
The Evening Standard 27 July 1996: 9; $\underline{\mathrm{H} 236}$ ) and his Under the Bridge p.155; Hogg Loose Strides pp.39-40, 45.

A2. 'Mr Thorpe.' Mate 4 (Feb. 1960): 10-14.

Sketch, told in the first person, reworked as 'In for my chop' in A Good Keen Man.

Reprinted in Bernard Gadd, ed. My New Zealand. Senior, with a Foreword and Questions. Auckland: Longman Paul Ltd, 1973. xi,114pp 0582668743. Pp. 1-6.

Reprinted in John Gordon, ed. Out of Town, Writing from the New Zealand Countryside. Christchurch: Shoal Bay Press, 1999. 344pp 090870495X. Pp. 25761.

A3. ' '.. That way.' Otago University Review 1962: 10-19 (ill., probably by Geoff Adams).

This issue was reviewed by James K Baxter NZ Listener 19 Oct. 1962: 19 who noted "a story by Barry Crump far more hard-hitting than anything he has turned out for money".

Reprinted as 'That way' Man 57, 4 (March 1965): 18, 24 (with illustration). The Man version has some altered phrasing ("Dave didn't care" replacing "Dave didn't give a flax-basket of kumaras" and after "Joe came, paid them" an extra short paragraph adds "and left two dogs ... 'If they're no good to you just give them the bullet'..."). Man magazine, published in Sydney for the male market, announced "A Barry Crump Short Story" on the front cover, headlined next to "Those Wild Girls of Paris" and "Where Blondes are worth £10,000!".

Reprinted as 'That way' in Warm Beer and Other Stories. This final version is tightened here and there by paring a few phrases and is a little less graphic "There was a frothing, thumping sound" (as a dog's throat is cut) is omitted, and the ominous "he said in the voice he used for special occasions" is dropped at the very end.

The first version was reprinted in Otago University Students' Association Literary Review 1888-1988. An anthology edited by David Merritt. Dunedin, 1988. ISSN: 0111-445X. Pp. 71-5. (The story was also to have been included in an earlier anthology, Review 1888-1971: A Retrospective Anthology of the Literary Review published since 1888 by the University of Otago Students' Association. Edited by Kevin Jones and Brent Southgate. [Dunedin]: Bibliography Room University of Otago, 1972, but it was one of several pieces which "had to be jettisoned at the last moment simply to save money".)

A4. 'A bit of a break.' NZ Listener 9 Oct. 1964:5, 22 (ill. by W. Jenks). Reprinted (with some differences: Marion's lover not identified and a final paragraph 
added) in Warm Beer and Other Stories (and later in Barry Crump's Bedtime Yarns).

A5. 'A clean swap.' NZ Weekly News 21 Oct. 1964: 45-7 (ill. signed "Morgan").

Reprinted (minor changes, the barmaid 'Lucy' becoming 'Judy', etc.) in Warm Beer and Other Stories (and later in Barry Crump's Bedtime Yarns); the opening is also reworked as the opening of 'Big Salty' in Gulf.

A6. 'Bill goat.' NZ Listener 30 Oct. 1964: 5 (ill. by Roger Hart). Incorporated (with minor changes) in Chapter 4 'The same sort of trouble' in The Odd Spot of Bother.

A7. 'Twice bitten.' NZ Listener 11 Dec. 1964: 5, 24 (ill. by Roger Hart).

Revised version (omitting first third) in Warm Beer and Other Stories (and later in Barry Crump's Bedtime Yarns).

A8. 'The wonderful West Coast sand mullet.' Read by Crump on radio (Open Country, National Programme, 25 July 1965); NZ Listener 20 Aug. 1965: 25 (with photo of Crump and Jim Henderson).

The story provoked a letter 'The sand mullet' in NZ Listener 24 Sept 1965: 11 signed 'M. D. Cranko (Christchurch)': "...two things jarred ... the unfamiliarity of the fish [and] familiarity with the story 'Sammy the sand mullet'... by Del [sic] Stivens ...". This story, in Dal Stivens's The Gambling Ghost and Other Tales. Sydney: Angus \& Robertson, 1953, has the same basic plot (and ending) as Crump's, although Crump tells it in his own style and words.

This version of the story and Cranko's letter (abridged) are reprinted in Mary Crockett and Terry Snow, ed. The Listener Bedside Book No 2. Auckland: W \& H Publications, 1998. 304pp 1877214027. Pp.30-1. Revised version (the setting changed from New Zealand to Australia) as 'Overheard in the pub' in Warm Beer and Other Stories (and later in Barry Crump's Bedtime Yarns).

A9. 'Horseplay.' NZ Weekly News 8 Sept. 1965: 37-8 (ill. signed "Morgan").

Reprinted (slightly expanded) as 'Horseplay' in Warm Beer and Other Stories (and later in Barry Crump's Bedtime Yarns).

A10. 'Lawful excuse.' NZ Weekly News 3 Nov. 1965: 41-2 (ill., unsigned).

Reprinted (expanded, ending changed) as 'Lawful excuse' in Warm Beer and Other Stories (and later in Barry Crump's Bedtime Yarns); later filmed as 'A Lawful Excuse' (1ㅡ).

Kōtare 4, no. 2 (2001), pp. 3-160. 
A11. 'The odd hitch' Mate 16 (Spring 1968): 16-23.

Short story, reworked as 'A stroke of luck' in Warm Beer and Other Stories (and later in Barry Crump's Bedtime Yarns). Cover illustration of this issue is a drawing of Crump by Murray Grimsdale.

A12. 'Clarry Anything.' New Zealand School Journal 1974 Part 4 No.2: 63-9 (2 ills by Tom McWilliams).

An extract (omitting beginning and end) from chapter 'Some good keen men' in A Good Keen Man (two small alterations - 'flaming well' for 'bloody well' and 'Flaming well Clarry' for 'Bloodywell Clarry'). The editor of the School Journal at the time was his long time friend Jack Lasenby whom Crump had met in the 1950s as a fellow government hunter, "'an academic sort of chap who was doing a spot of deer culling' ... It was Lazenby [sic] who at the end of the season introduced Crump to a circle of artistic friends in Auckland ..." (Ivan Agnew, Sunday News 3 June 1973: 23; $\underline{\text { H67)}}$ ).

A13. 'Early reading. New Zealand writers describe books that impressed them in their childhood. Barry Crump on Coral Island.' Education 25, 9 (1975): 27 ("...marooned on a desert island ...To us, then, it was a wonderful dream of things exactly the way we reckoned they ought to have been ... That dream came true years later ... we were shipwrecked on beautiful Lizard Island...").

Reprinted in Book Counsel, Newsletter of the New Zealand Book Council 31 (Feb. 1980): 5-6.

The editor of Education at the time was Roger Hall (see his Bums on Seats, 1998; H269).

A14. 'More golf.' New Zealand Golf Magazine Aug. 1980:11-12 (with 2 photos of Crump).

Story, reworked as 'May' in Shorty (written in the Cook Islands; "I began to write an article up there for a golf magazine - but it grew and grew to a 45,000-word book": Auckland Star 4 Oct. 1980: see B15, $\underline{\text { H84}}$ ).

A15-A40. 'Crump Country', a regular column by Crump in Southern Skies which he was asked to contribute by editor Colin Hogg after his interview with Crump

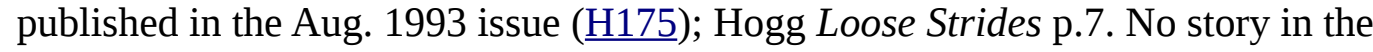
March 1995 issue; June 1995 not seen.

A15. 'Mrs Windyflax and the Pungapeople of Punakaiki.' Sept. 1993: 32-4, 38-9 (7 ills by Kerry Emmerson).

Poem, previously published by photo-copying 1983 (B17) and with slight differences (notably the omission of stanza 4) in Bedtime Yarns; new edition with

Kōtare 4, no. 2 (2001), pp. 3-160. 
ills by Murray Ball, 1995.

A16. 'Post taste.' Oct. 1993: 26, 28-30 (photos of letterboxes with accompanying text). Text reprinted as 'The Kiwi postbox' in Forty Yarns.

A17. 'Turn left at Memory Lane.' Nov. 1993:36-8 (col. ill. by Anthony Ellison). Expanded as 'The Kiwi bomb' in Forty Yarns.

A18. 'The man time forgot...' Dec. 1993-Jan. 1994: 26-8 (col. ill. by Anthony Ellison). Reprinted (omitting last five sentences) as 'Anachronology' in Forty Yarns.

A19. 'Strife on the ocean waves.' Feb. 1994:28-30 (col. ill. by Anthony Ellison). Expanded as 'The Wayfarer' in Forty Yarns.

A20. 'One in the Bull's Eye.' March 1994: 24-6 (col. ill. by Anthony Ellison). Reprinted as 'The Brahman Bull' in Forty Yarns.

A21. 'Letter to the IRD.' April 1994: 20-2, 24 (col. ill. by Anthony Ellison). Poem, previously published in Bedtime Yarns. Reprinted in Forty Yarns and in Song of a Drifter.

A22. 'Three-dog night.' May 1994: 30-2 (col. ill. by Anthony Ellison). Reprinted as 'Three dog night' in Forty Yarns.

A23. 'Jam packed.' June 1994: 20-2 (col. ill. by Anthony Ellison). Reprinted (final sentence changed) as 'Strawberry jam' in Forty Yarns.

A24. 'Safari in Ghuznee Street.' July 1994: 20-3 (col. ill. by Anthony Ellison). Reprinted (slightly revised) in Forty Yarns.

A25. 'Night of The BB and BB.' Aug. 1994: 20-2 (col. ill. by Anthony Ellison). The end is reworked from an episode in Chapter 2, 'A bit of a lean spell', in The Odd Spot of Bother.

A26. 'On a dead cert.' Sept. 1994: 36-9 (col. ill. by Anthony Ellison). Reprinted as 'A dead cert' in Forty Yarns.

Kōtare 4, no. 2 (2001), pp. 3-160. 
A27. 'A real Kiwi joker.' Oct. 1994: 44-7 (col. ill. by Anthony Ellison). Reprinted as 'Sense of humour' in Forty Yarns.

A28. 'Basil, nannies and the kids.' Nov. 1994:44-7 (col. ill. by Anthony Ellison). Reprinted (slightly revised) as 'Clive's goats' in Forty Yarns.

A29. 'Back when I was a boy.' Dec.1994-Jan.1995: 60, 62-3 (col. ill. by Anthony Ellison).

Reprinted as 'Formative years' in Forty Yarns.

A30. 'Snakes alive!' Feb. 1995: 28-31, 34 (col. ill. by Anthony Ellison). Reprinted as 'Garth' in Forty Yarns.

A31. 'A bit of bad luck.' April 1995: 42-4, 46-7 (col. ill. by Anthony Ellison).

Reprinted as 'Unfortunate experiences' in Forty Yarns.

A32. 'Taken for a ride.' May 1995: 58-63 (col. ill. by Anthony Ellison). Reprinted as 'The Eastern touch' in Forty Yarns.

A33. 'Fear of heights.' July 1995: 40-2 (col. ill. by Anthony Ellison). Reprinted as 'On the cutting room floor' in Crumpy's Campfire Companion.

A34. 'Down on the farm.' Aug. 1995: 38-9, 42 (col. ill. by Anthony Ellison).

Reprinted (slightly revised) as 'The real thing' in Crumpy's Campfire Companion.

A35. 'Stag party.' Sept. 1995: 30-2 (col. ill. by Anthony Ellison). Reprinted as 'By the seat of our pants' in Crumpy's Campfire Companion.

A36. 'A long haul.' Oct. 1995: 50-1 (col. ill. by Anthony Ellison). Reprinted in Crumpy's Campfire Companion.

A37. 'Hard yakker.' Nov. 1995: 42-6.

Reprinted (slightly revised) under same title in Crumpy's Campfire Companion.

A38. 'Bottom of the barrel.' Dec.1995-Jan.1996: 38-40 (col. ill. by Anthony Ellison).

Reprinted as 'The man from the bottom of the barrel' in Tall Tales and True (드).

A39. 'No trouble...' Feb. 1996: 42-5 (col. ill. by Anthony Ellison). Reprinted as 'No trouble' in Crumpy's Campfire Companion.

Kōtare 4, no. 2 (2001), pp. 3-160. 
trouble' in Crumpy's Campfire Companion.

A40. Thanx for the memory.' March 1996: 34-6 (col. ill. by Anthony Ellison).

Reprinted as 'Cutie-pie' in Crumpy's Campfire Companion.

\section{B. Books Written by Crump}

B1. A Good Keen Man 1960

Barry Crump | [swelled rule] | A GOOD KEEN MAN | Illustrated by Dennis Turner | [publisher's device] | WELLINGTON | A. H. \& A. W. REED

"First published 1960" (verso-title). 192pp., fawn boards, 223mm; red dustjacket. Printed by Halstead Press, Sydney, Australia. 16s.

Sketches loosely forming a novel, two revised from stories earlier published in Mate (Al, $\underline{\mathrm{A} 2}$ ). The final text was considerably revised from Crump's original version (notably a change of narration from third to first person) by journalist Alex Fry at the request of Ray Richards of Reeds who accepted the book after at least two other publishers rejected it. (Richards later said of the manuscript: "[it] arrived grubby and single spaced but with a 'magic' about it": The Publisher 70 (Aug. 2001); H317.) In the book Crump thanks (p.6) "Kevin Ireland, who insisted that I start work" and "Alex Fry, who gave invaluable help towards its completion". 'Sixpence an hour' in Forty Yarns is Crump's account of the publication of the book and of Fry, "the journalist Mr Richards had engaged to help me knock my novel into shape ... we became good friends and for several months spent most of our evenings shuffling the material into sequence and eliminating repetition and filling in gaps and generally getting the_book to flow...". See Hogg Loose strides pp.51ff for the book and Fry's work on it, and p.57 for Crump's later attack on Fry (Fry received a percentage of the royalties and a broken nose and ribs). Richards's account in Tribute (p.73) says "I changed the narrator from Jack Somebody to Barry Crump himself" (see also NZ Herald 4 July 1996: 20; $\underline{\text { H212) }}$ ), though Ireland in Tribute (p.66) points out that they wrote the original story [not the novel] together and it was in the first person. In his eulogy at Crump's wake (quoted in 'Barry Crump: an unforgettable man' The Evening Standard 27 July 1996: 9; H236) Ireland says (of the story in Mate): "We wrote the first draft of Barry's first story together ... I said I'd type while he recited ... we had several goes at the story during the next few days ... [then] I dropped out altogether ... he worked like a slave at becoming a writer ... He began A Good Keen Man in 1957, and worked on and off on his manuscript until he finished it toward the middle or end of 1959.".

Crump later expressed a wish to publish the original version ('Crump moves on' Listener 21 Feb. 1981: 107-8; H89): "The only writing from his past he does express a keen interest in is the first draft of A Good Keen Man. 'Reeds ... made me rewrite it extensively. I had it in the third person and it was a big change to

Kōtare 4, no. 2 (2001), pp. 3-160. 
the first person dated July 1959 with annotations and revisions, donated by Fry in 1975 (p.2 is reproduced in Hogg's Loose Strides and may be compared with p.13 of the book).

Later printings:

2nd impression: 1961: "First published 1960 | Reprinted 1961".

3rd: 1961: "[...] | Reprinted 1961 (twice)".

4th: 1961 unseen.

5th: 1961: "[...] | Reprinted 1961 (four impressions)" (on dust-jacket flap: "completing 23,000 copies").

6th: 1961: "[...] | Reprinted 1961 (five impressions)" ("completing 28,000 copies"). Red boards.

7th: 1961 unseen.

8th: 1962: "[...] | Reprinted 1961 (six impressions) | Reprinted 1962" ("completing 36,000 copies"). Red boards.

9th: 1962: "[......] | Reprinted 1962 (two impressions)" ("completing 41,000 copies").

10th: 1962: "[...] | Reprinted 1961 (six impressions) | Reprinted 1962 (four impressions)" ("completing 46,000 copies"). Red boards.

11th: 1962 unseen.

Reprint in omnibus, 1962: Two in One (B33).

12th: 1964: "[ ...... ] | Reprinted 1962 (four impressions) and 1964" ("completing 54,000 copies"). Red boards.

Australian paperback edition 1965: Sydney: Ure Smith [1965] (Humorbooks). 192pp., white pictorial wrappers, $185 \mathrm{~mm}$. Printed by Halstead Press, Sydney, Australia; offset from Reed edition. "Published in New Zealand by A.H. \& A.W. Reed, Wellington". A\$0.80c; NZ 6s 6d. This paperback was reprinted: "Second impression 1968". Printed by Peninsula Press Ltd., Hong Kong; offset from earlier edition; size and binding as 1965 printing. A\$0.80c; NZ 65c. Reed reprint 1969 unseen.

Reed reprint 1974: "[......] 1964 | Published as Humorbooks paperback

1965 | This cased edition 1969 | Reprinted 1974". Red boards. Printed by Dai Nippon Printing Company (Hong Kong) Ltd.; offset from earlier edition. SBN:

Kōtare 4, no. 2 (2001), pp. 3-160. 
1965 | This cased edition 1969 | Reprinted 1974". Red boards. Printed by Dai Nippon Printing Company (Hong Kong) Ltd.; offset from earlier edition. SBN: 58900400 X. In 1978 Reeds remaindered the last 2,000 copies.

New edition 1982: [Auckland] Firstlight Productions,1982: "[ ...... ] |

Reprinted 1974 | This cased edition 1982". 192pp., pale grey boards, 221mm; pale green dust-jacket. Printed by Business Printing Works Ltd., Auckland; offset from earlier edition. 058900400X. \$13.95 (in the ATL copy the ISBN is corrected in pencil to 0-9597654-0-9).

New edition 1985: [Auckland] Beckett Publishing, 1985. "First published 1960 A.H. Reed | This seventeenth printing by | Beckett Publishing 1985". 192pp., green wrappers, 212mm. "Printing through Communication Arts Ltd"; offset from earlier edition. 0908676700. Reprint March 1987: Adds "Reprinted March 1987"; otherwise as preceding. New edition 1994: [Opotiki]: Barry Crump Associates [1994]. 192pp, green wrappers, 212mm. "Published by Moa Beckett Publishing Ltd | [ ... ] Auckland | First edition 1960 | Reprints numerous | This edition 1994". (Printed by Australian Print Group.) 095978973.

New edition 1995: Auckland: Hodder Moa Beckett, 1995. 192pp., brown wrappers, 210mm. Printed by McPherson's Printing Group, Australia. 0959789723. \$24.95. At head of cover: "A New Zealand classic". Reprint 1996: "This edition published in 1995 | Reprinted in 1996"; otherwise as preceding.

Crump's list in Life and Times gives total sales by Sept. 1991 as 275,000 copies. Ray Richards (Tribute p.74) talks of a total to 1996 of "300,000 copies ... and six million dollars (retail value)".

The book was broadcast on the National Programme in 13 episodes beginning 26 April 1961, read by Bernard Kearns (recording held at Radio NZ Sound Archive). A review of the first episode (NZ Listener 9 June 1961: 34) was very favourable and praised Kearns's reading - "How I wish, though, that the author had been persuaded to read the book to us himself". In fact Crump had been forbidden to

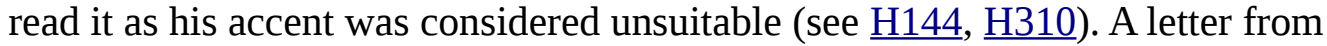
the NZBC to Reeds (ATL MS-Papers-6548) dated 16.2.69 sought world rights to the radio serials of A Good Keen Man and Hang on a Minute Mate offering \$150. The original fee paid was \$200. The reading was rebroadcast in July 1996 following Crump's death. A sound recording of the book, read by Crump himself, was produced by the Royal New Zealand Foundation for the Blind in 1967 (1 sound cassette 4 hrs, 30 min.). See also $\underline{\mathrm{H} 39}$ and Hogg Loose Strides p.101 ("In July [1966], Crump takes up an invitation to make a contribution to Braille Week by recording readings...") and plate of Crump making the recording. The dustjacket flap of Fred says of A Good Keen Man: "Even the Russians translated some of it and published their copy in Russia!". And Crump is quoted (Auckland Star 30 May 1970; $\underline{\text { H48) }}$ ) as saying that his total sales include "more than 100,000 for the Russian edition of A Good Keen Man". No Russian translation of A Good Keen Man has been traced. Reeds received letters in 1970 from Bulgarian

Kōtare 4, no. 2 (2001), pp. 3-160. 
best humourists of our century", in a planned anthology of world humour. The anthology has not been traced and may never have been published. (The Bulgarian National Library informed me by email (11.10.01) that "an anthology of world humor was published in Bulgaria in 1996, but unfortunately no New Zealand's author was included".) Kolev also suggested he write an article for Landfall which "will show how New Zealand thanks to Barry Crump's talent may claim to take a leading place among nowadays humour writers of the world" (ATL MS-Papers-6548: letters dated 15.1.70, 19.2.70, 25.3.70; 14.4.70; it seems there was an earlier letter that has not survived); see also Hogg Loose Strides p.118. Crump tried to locate Kolev when he was in Bulgaria in 1973, unsuccessfully (Life and Times p.135).

Chapter titles: 'I become a deer culler', 'Flynn becomes a pig-dog', 'That healthy outdoor life', 'Some good keen men', 'I meet Harry', 'Trouser trouble', 'I hunt the cocky's pigs with Jim', 'I meet Legs', 'In for my chop', 'Harry again', 'A good keen dog', 'Two prize heads', 'Wilmer', 'Not quite so keen', 'I go to town', 'I hunt without Bert', 'Fatted calf and brave bull', 'I live in Te Whenua o Te Hine Nui o Te Po'.

\section{Extracts reprinted:}

End of 'I become a deer culler' and all of 'That healthy outdoor life', 'Some good keen men', 'I meet Harry', 'I hunt the cocky's pigs with Jim', 'I meet Legs', 'In for my chop', 'Harry again', 'Two prize heads' and 'Wilmer' reprinted as 'Some good keen men' in The Best of Crump. Extract (middle section) from 'Flynn becomes a pig dog' reprinted as 'Flynn' in D.A. Bethell \& E.K. Ryburn, ed. New Zealand Scene, Extracts and Exercises for Use in Comprehension and Composition. Auckland: Paul's Book Arcade, 1962. 60pp. Pp.9-11.

Extract (pp.72-4) from 'Trouser trouble' reprinted as 'Ron Something-or-Other' in J.C. Reid, ed. A Book of New Zealand. Auckland, Collins, 1964. 351pp. Pp.242-4 (reprinted 1971; revised edition ed. J.C. Reid and P. Cape. Auckland: Collins, 1979. xx,292pp.: same extract pp.198-9). 'That healthy outdoor life' reprinted in P.R. Smart. Exploring New Zealand Writing, An Anthology for Senior Students. Wellington: A.H. \& A.W. Reed, 1964. 160pp. Pp. 141-5.

Brief extract from 'That healthy outdoor life' reprinted as a punctuation exercise in P.R. Smart. Let's Learn English 3, A Year's Assignment in English for Third Forms. Wellington: A.H. \& A.W. Reed, 1966. P.87 ("Reprinted (twice) 1967").

'A good keen dog' and most of 'Flynn becomes a pig-dog' (omitting end) reprinted as 'A place for handy dog-tucker' in Jack Pollard, ed. Wild Dogs, Working Dogs, Pedigrees \& Pets. Dog and Man in Australian and Nezv Zealand Life. Wellington: A.H. \& A.W. Reed, 1968. xiii,297pp. Pp.115-22 and pp.219-24.

Extract (omitting beginning and end) from 'Some good keen men' reprinted as 'Clarry Anything' in New Zealand School Journal 1974 Part 4 No.2: 63-9 (ㅅ12).

Kōtare 4, no. 2 (2001), pp. 3-160. 
'Clarry Anything' in New Zealand School Journal 1974 Part 4 No.2: 63-9 (ㅅ12).

Extract from 'That healthy outdoor life' (pp.31-4 omitting two paragraphs) reprinted in P.R. Smart. Process and Product, English for New Zealand Sixth Forms. Auckland: Longman Paul, 1979. 0582683335. [x],213pp. Pp.25-7.

Most of 'Harry again' (pp.110-7, omitting beginning) reprinted in Philip Temple, ed. Lake, Mountain, Tree, An Anthology of Writing on New Zealand Nature \& Landscape. Auckland: Godwit, 1998. 287pp. 1869620224. Pp.201-6. Extract (pp.13-15) from T become a deer culler' reprinted as autobiographical in Hogg Loose Strides pp.28-30; further extracts pp.61-3.

B2. Hang on a Minute Mate 1961

[drawing by Dennis Turner of Sam Cash, elbow leaning on first word of title] HANG | ON | A | MINUTE | MATE | by | Barry Crump | AUTHOR OF A Good Keen Man | WELLINGTON [publisher's device] |A. H. \& A. W. REED

"First published 1961" (verso-title). 192pp., red boards, 223mm; maroon dustjacket. 18 line drawings by Dennis Turner. Printed by Halstead Press, Sydney, Australia. 16s.

Episodic novel. Crumps says in Life and Times (pp.66-7): "... A Good Keen Man was a runaway success ... would I be interested in writing another book? I wrote it in about three weeks and called it Hang on a Minute Mate. It was my first venture into proper fiction...". Ray Richards in Tribute (p.74) talks of Alex Fry "polishing the text" of this book also, which Crump implies in 'Sixpence an hour' in Forty Yarns was not the case. "First printing 15,000 copies" (dust-jacket flap); this "sold out ... in a fortnight" (flap of Good Keen Man, 6th impression).

Later printings:

2nd impression: 1961: "First published 1961 | Reprinted 1961" ("completing 20,000 copies" — dust-jacket flap).

3rd: 1961: "First published 1961 | Reprinted 1961 (two impressions)" ("completing 30,000 copies").

4th: 1962: "[...] | Reprinted 1961 (two impressions) | Reprinted 1962" ("completing 37,000 copies").

5th: 1962: "[ ......] Reprinted 1962 (two impressions)" ("completing 41,000 copies").

6th: 1962: "[ ......] Reprinted 1962 (four impressions)" ("completing 47,000 copies"). 
Bodley Head, 1963. 192pp., green boards, 203mm; dark brown dust-jacket. Printed by Lowe \& Brydone (Printers) Ltd., London (offset from Reed edition). (See Hogg Loose Strides pp.83-4: royalties to Fleur Adcock; the dust-jacket flap of One of Us states that Hang on a Minute Mate "is published in London by Werner Laurie Ltd.").

8th: 1965: "[......] Reprinted 1962 (four impressions) | Reprinted 1965" ("completing 50,000 copies").

9th? The House of Reed 1957-1967 (H44; p.53) states nine printings. Paperback edition 1966: Humorbooks. Ure Smith, Sydney. A.H. \& A.W. Reed, Wellington, 1966. 192pp., mustard wrappers, $184 \mathrm{~mm}$. Printed by the Continental Printing Co., Ltd., Hong Kong. "Available July 1966" — list inside back cover. A\$0.80c; NZ 6s6d.

Reed reprint 1970: "First published 1961 | This edition 1970". Red boards; blue dust-jacket. Printed by Dai Nippon Printing Co. (International) Ltd., Hong Kong. SBN: 589000829.

New edition 1996: Auckland: Hodder Moa Beckett, 1996. 187pp., wrappers, 210mm; (on verso-title: "First published in 1961 by Barry Crump Associates [sic] | This edition printed in 1996". Typeset by TTS Jazz, Auckland; printed by Griffin Paperbacks, Australia. 1869584635. At head of cover: "A New Zealand Classic". The only textual alteration noticed (apart from incorrect "model a truck" for "Model A Truck" at the beginning of 'Jack') is "headlamp" for "headlight" at the beginning of 'The Pahau Valley pub'. Several stories in the original printing are set without quotation marks around direct speech; in the reprint this has been normalised.

Crump's list in Life and Times gives total sales by Sept. 1991 as 155,000 copies.

Unsuccessful attempts were made to market the book overseas: "...Continental and American rights are being negotiated" says a note in the Evening Post 17 Sept. 1962; $\underline{\mathrm{H} 23}$ ) and a Reed memo of 18.9.70 (ATL MS-Papers-6548) states that a German literary agent had offered it to 14 publishers. Two stories were translated into Russian (see below). A Braille edition was produced (3 volumes of Interline Braille (Grade 2)), and also a sound recording, read by the author. [Auckland]: Royal New Zealand Foundation for the Blind [1989?]: 3 sound cassettes (4 hrs); this is presumably a reissue of Crump's reading of this work and of A Good Keen Man made for Braille Week in 1966 (see $\underline{\text { H39; }}$ Hogg Loose Strides p.101 and photo).

The book was broadcast on radio in 13 episodes, read (unlike his first book) by Crump himself (held at Radio NZ Sound Archive). A memo of 23.7.70 in the Reed file at ATL (MS-Papers-6548) discusses an American approach for film rights which came to nothing, but the book was filmed for television in 1984 (D2) and a stage play by Anthony McCarten based on the book was produced in

Kōtare 4, no. 2 (2001), pp. 3-160. 
rights which came to nothing, but the book was filmed for television in 1984 (D2) and a stage play by Anthony McCarten based on the book was produced in 1992 (D3).

Chapter titles: 'Sam', 'Jack', 'A tidy heap', 'No sense of humour', 'A bunch of brumbies', 'The unluckiest bloke on earth', 'Harvey Wilson's run', 'The muster', 'The Pahau Valley pub', 'Uncle Wally', 'Hard grafting', 'Not guilty, sir', 'Women!', 'Mrs Wagner', 'The way the truck turns', 'Sorry, mate', 'Hang on a minute mate'.

\section{Extracts reprinted:}

'Sam', 'Jack', 'The Pahau Valley pub', 'Not guilty, sir', 'The unluckiest bloke on earth', 'The muster', and part (pp.37-42) of 'No sense of humour' reprinted (in this shuffled order) in The Best of Crump. 'Sam', 'Jack', 'A tidy heap', 'No sense of humour', 'A bunch of brumbies', 'Harvey Wilson's run', 'The muster', 'The Pahau Valley pub', 'Uncle Wally', 'Hard grafting', 'Not guilty, sir', 'Women!', 'Mrs Wagner', 'The way the truck turns', 'Sorry, mate', 'Hang on a minute mate' reprinted in The Adventures of Sam Cash.

Beginning of 'A tidy heap' paraphrased as 'Truck trouble' in Joy Collins and Peter Smart, Ed. Stories for You, Series 1, Book 1. Wellington: A.H. \& A.W. Reed, 1960. 127pp. Pp. 111-4.

Extract from 'Hard grafting' (pp. 123-5 with slight changes) reprinted as 'Uncle Wally's pacer' in Jack Pollard, Ed. Horses and Horsemen: Wild Bush Horses, Thoroughbreds, and the Men who Rode Them. Melbourne: Lansdowne Press, 1965. xiii,316pp. Pp.300-1. Also published with imprints: Wellington, A.H. \& A.W. Reed, and London: Newnes; new edition Sydney: Jack Pollard Publishing, 1974. 0909950822; new edition as Great Horse Stories of Australia and New Zealand. Adelaide: Rigby [1977]. vi,385pp. 0727004824. Beginning of 'A tidy heap' reprinted as 'Does your speedo work?' in Jack Pollard, d. One for the Road, Stories of Racetrack, Trials, Pioneer, Veteran, Vintage, and Outback Motoring in Australia and New Zealand. Sydney: Angus and Robertson, 1966. xvi,255pp. Pp.251-3; [2nd ed.] Sydney: Pollard Publishing, 1974. 0909950849; also issued with imprint: Wellington: A.H. \& A.W. Reed, 1974. "ISBN: 589-00897-8" (on dust-jacket: "The Legend of _ Australian and New Zealand Motoring"); reprinted as Great Motoring Stories of Australia and New Zealand. Adelaide: Rigby Limited [1976] 0727001981.

'Sam' and extract (pp.88-9) from 'The muster' reprinted in A.T. Johnson and M.O. Johnson, ed. Dialogue, Study Themes for Fifth and Sixth Form English.

Christchurch: Whitcombe \& Tombs Ltd, 1973.180pp. 0723303762. Pp.21-2 (with questions p.23 and p.33).

Extract from 'No sense of humour' (p.46; "fifty-six pounds" modernised into "one hundred and twelve dollars"; "bloody" sanitised to "bâ€”") reprinted in P.R.

Smart. Message and Meaning, Let's Learn English 5 in the 70s. Wellington: Reed Education, 1975. ix,256pp. 0589050745. P.73. 'Jack' reprinted as 'Car episode' in

Kōtare 4, no. 2 (2001), pp. 3-160. 
0370109465. Pp.31-6. 'Jack' reprinted as 'Sam the saviour' in Kerstin Andersson \& Karl Erik Hedstrom, ed. Insight 2, The Choice Insight Series. [Stockholm] Natur och Kultur, 1979 (1980 reprint seen). 200pp. 912758707X. Pp.148-52. (An English language textbook for Swedish pupils; letter seeking permission to use the extract in ATL MS-Papers-6548.)

First half of 'A tidy heap' and all of 'The Pahau Valley pub' reprinted in Gordon McLauchlan, ed. The Acid Test, An Anthology of Nezv Zealand Humorous Writing. Auckland: Methuen Publications (New Zealand) Ltd, 1981. [x],213pp. SBN: 45602940 0. Pp.86-95.

Same extract reprinted as 'Old Gertie' in Gordon McLauchlan, ed. A History of Nezv Zealand Humour. Auckland: Penguin Books (NZ) Ltd, 1989. 231pp. 0140102205. Pp.103-13.

Extract from 'Women!' (pp.144-5) reprinted in Kevin Ireland. The New Zealand Connection, A Celebration of the New Zealand Novel. Auckland: Random House, 1989. (1ㅡㄴ). Pp.67-9.

'Sam' reprinted as autobiographical in Hogg Loose Strides pp.47-8. "The Pahau Valley pub' and 'Not guilty, sir' were translated into Russian by la. Berlin as 'Gostinitsa Pakhau-Velli' and 'Ne vinoven, ser' in E. Dombrovskaia, ed. Novozelandskie Rasskazy, Perevody s angliiskogo. Introduction by V. Rubin. Translations edited by N. Gal'. Illustrated by A. Beliukin. Moscow: Isdatel'stvo Khudozhestvennoi Literatury, 1963.446pp. Pp.417-24, 425-8. This anthology of New Zealand short stories (drawing heavily on "the life-affirming democratic literature of New Zealand") with introduction and biographical notes was reviewed in Fernfire 12 (Oct.

1964): 30-1 (in which periodical many of the stories first appeared) and by $\mathrm{H}$. Winston Rhodes as 'New Zealand stories for Russian readers' in Landfall 70 (June 1964): 158-60, an article Dan Davin found "disingenuous" (Keith Ovenden. A Fighting Withdrawal, The Life of Dan Davin, Writer, Soldier, Publisher. Oxford: Oxford University Press, 1996, pp.322-3); see also Michael King, Frank Sargeson, A Life. Auckland: Viking, 1995, pp.366-8 for other reactions to the anthology. John Goodliffe 'New Zealand literature in Russian: three anthologies' New Zealand Slavonic Journal 1994: 45-56 notes some omissions and mistranslations in the Crump stories (notably 'Hang on a Minute Mate' translated as if it meant 'hold on to your friend') and observes that the print-run of 50,000 was "comparatively low".

B3. Two in One 1962

BARRY CRUMP | TWO | IN | ONE | [rule] | A GOOD | KEEN MAN | \& | HANG ON A | MINUTE MATE | [rule] | [publisher's device] | REED

Title from spine of book. On dust-jacket: "[Dennis Turner drawing of a character from each book] BARRY CRUMP'S | TWO IN ONE | COMPLETE TEXT OF

Kōtare 4, no. 2 (2001), pp. 3-160. 
Title from spine of book. On dust-jacket: "[Dennis Turner drawing of a character from each book] BARRY CRUMP'S | TWO IN ONE | COMPLETE TEXT OF THE TWO BOOKS 'A GOOD KEEN MAN' \& 'HANG ON A MINUTE MATE' | WITH 37 ILLUSTRATIONS BY DENNIS TURNER 384 PAGES PRICE 21s. (N.Z.)".

192,[2],192pp., red boards, 204mm; olive green dust-jacket. 21s.

This omnibus of A Good Keen Man and Hang on a Minute Mate has no general title-page and was a happy solution to an accident at the printers who were simultaneously producing new runs of 5,000 copies each of the two books: "The Sydney manufacturers phoned ... to say they had inadvertently bound the books inside the wrong covers ... My solution was to guillotine the 10,000 books out of their covers and bind them together as a 'Crump Special' ..."(Ray Richards Tribute p.74). Crump tells the story in Life and Times (p.69): "[In Sydney Jean Watson] got a job at the place where my books were being printed, Halstead Press, which was a bit lucky for them because it was Jean who noticed that a run of my first two books they were doing were mixed up. They had half of one book and half the_other bound together. They guillotined them apart, shuffled them into sequence and bound it all together under the title Two In One."; see also Hogg Loose Strides pp.63, 68. Crump's list in Life and Times gives the total number of copies sold as 10,000, presumably an error for 5,000.

B4. One of Us 1962

[set left] BARRY CRUMP | [set right:] ONE OF US | Illustrated by Dennis Turner | [set left:] A. H. \& A. W. REED, Publishers | [line drawing by Turner]

"First published 1962" (verso-title). 181pp., brown boards, 222mm; khaki dustjacket. (Printed by Halstead Press, Sydney, Australia). 16s.

Novel. Crump left the book without an ending, which was supplied by Ray Richards of Reeds: "I had to write the final chapter ... because Crump had 'gone bush' and the printers were waiting" (Richards Tribute p.74); see also Hogg Loose Strides pp.69-70. The ending was changed by Crump in later editions. Crump was awarded the Hubert Church Award ("the best prose published in the previous year") for this book in 1962 (ATL MS-Papers-73-161, Box 4; not for There and Back as he states in Life and Times p.69). The book was broadcast on radio in 13 episodes, read by Crump (held at Radio NZ sound archive).

Later printings:

2nd impression 1962: "First published 1962 | Reprinted 1962"; red boards.

3rd impression 1963: "[...] | Reprinted 1962 and 1963"; brown boards.

Australian (paperback) edition, 1968: Sydney: Ure Smith [1968] (Humorbooks).

Kōtare 4, no. 2 (2001), pp. 3-160. 
wrappers, 210mm. "First edition 1962 | Reprints numerous | This edition 1992". "Printed by Australian Print Group, Vic. 3465". 0959789782. \$19.95.

New edition 1994: Auckland: Hodder Moa Beckett, 1994. Unseen — details probably as next.

Reprint 1997: Auckland: Hodder Moa Beckett, 1997. On verso-title: "First edition 1962 | Reprints numerous | This edition 1994 | Reprinted 1997". 185pp., wrappers, 210mm. Printed by McPherson's Printing Group, Australia.

186958578X. Pp.9-176 of this edition are reprinted from the Reed edition but the pre-_liminary pages and pp.177 to end are reset: the chapter 'One of us' is lengthened by two pages, and 'Got a light on you, mate?' loses its penultimate paragraph and the final paragraph is printed separately with a blank page in between. 'Got a light on you, mate?' now begins on p.181 not p.179 but the list of contents, though reset, repeats the original pagination. Crump's list in Life and Times gives total sales by Sept. 1991 as 70,000 copies.

Chapter titles: 'Sam ... and Ponto', 'Shai's yarn', 'Dan's yarn', 'Four pounds ten', 'Men at work', 'Hospitality', 'Toddy', 'Toddy in trouble', 'T. Bourke', 'West Coast pub', 'On contract', 'An inside job', 'Crook boots', 'Pay Sam and Ponto', 'Heading north', 'The last drink', 'One of us', 'Got a light on you, mate?'.

\section{Extracts reprinted:}

'Shai's yarn', 'Dan's yarn', end of 'Hospitality', most of 'Toddy' (omitting end), all of 'Toddy in trouble' and 'On contract' reprinted as 'Shai's yarn' in The Best of Crump.

'Shai's yarn' (as 'Toms [sic] Yarn') and 'Dan's yarn' (as 'Dan's luck'; omitting end) reprinted in Barry Crump's Bedtime Yarns.

\section{B5. $\quad$ There and Back 1963}

[set left:] BARRY CRUMP | THERE AND BACK | Illustrated by Dennis Turner | A. H. \& A. W. REED, Publishers | [set right: illustration by Turner]

"First published 1963" (verso-title). 187pp., grey boards, 223mm; orange dustjacket. Printed by Halstead Press, Sydney, Australia. 16s.

Novel. Hogg Loose Strides pp.78-82 with extracts. Production cost to Reed was $£ 241$ 10s. (ATL MS-Papers-6548).

\section{Later printings:}

2nd impression, 1963: "First printed August 1963 | Reprinted September 1963". 
2nd impression, 1963: "First printed August 1963 | Reprinted September 1963".

3rd? The House of Reed 1957-1967 (H44; p.78) states three printings.

Australian (paperback) edition 1966: [Sydney] Humorbooks [1966]. 187pp., white wrappers, 184mm. On verso-title: "First published in Humorbooks 1966 | by Ure Smith Pty Ltd ... Sydney | and A.H. \& A.W. Reed ... Wellington, N.Z. | This international edition printed by | The Continental Printing Co. Ltd., Hong Kong" (offset from earlier Reed edition). A\$0.80c; NZ 6s6d.

New edition 1992: Opotiki: Barry Crump Associates, 1992; distributed by Beckett Sterling, Auckland. 187pp., green wrappers, 209mm. On verso-title: "First edition 1963 | Reprints numerous | This edition 1992". Printed by the Australian Print Group, Vic. 3465, Australia; offset from Reed edition. 0959789790. \$19.95.

New edition 1994: as preceding, with Barry Crump Associates imprint on titiepage but on verso-title: "Published by Moa Beckett Publishers Limited ... Auckland ... First edition 1963 | Reprints numerous | This edition 1994".

New edition 1996: Auckland: Hodder Moa Beckett Publishers Ltd, 1996. On verso-title: "First published in 1963 by Barry Crump Associates [sic] । This edition published in 1996". Printed by Griffin Paperbacks, Australia; offset from earlier edition. 1869584627. \$24.95. At head of cover: "A New Zealand Classic".

Crump's list in Life and Times gives total sales by Sept. 1991 as 65,000 copies.

Chapter titles: 'Nine bob an hour', 'Nine and six an hour', 'You never know', 'A shrewd move', 'Time flies', 'Old hammergun', 'Nothing but the best', 'A line of bull', 'Pete Atkins's pigs', 'The Reverend Mister Cash', 'Sam Cash, M.P.', 'Saddleblanket', 'Shabby dog', 'Six of one', 'Somewhere quiet for the off-season', 'Hokonui Hank', 'Arnie', 'It's a he!', 'Stony going', 'Bad to worse', 'Going', 'Home'.

\section{Extracts reprinted:}

'A shrewd move', 'The Reverend Mister Cash', 'Saddleblanket', 'Shabby dog', 'It's a lie!' reprinted as 'A shrewd move' in The Best of Crump. 'Nine bob an hour', 'Nine and six an hour', 'You never know', 'A shrewd move', 'Old hammergun', 'Nothing but the best', 'A line of bull', 'Peter Atkins's pigs', 'The Reverend Mister Cash', 'Sam Cash, M.P.', 'Saddleblanket', 'Shabby dog', 'Six of one', 'Somewhere quiet for the offseason', 'Hokonui Hank', 'Home' reprinted in The Adventures of Sam Cash. Two episodes, theft of a road roller from 'Times flies' and 'Hokonui Hank', were included in the film 'Hang on a Minute Mate' (D2).

\section{B6. Gulf (Crocodile Country) 1964}

BARRY CRUMP | GULF | Illustrated by Will Mahony | [publisher's device] | A. 
jacket. Printed at the Halstead Press, Sydney, Australia; 16s.

Novel about crocodile shooting in Gulf of Carpentaria, Australia, based on Crump's own experiences but "the story's largely fictional" (dust-jacket); Tiff is based on Jean Watson, 'Darcy' on their Latvian companion Harry Blumenthals (Harry Blue). Crump's less fictionalised version of his time in Australia is found in Life and Times pp.69-116 (with a note on Gulf p.99: "I had to fly back to New Zealand to negotiate a contract or something and got held up there for a bit, so I wrote a book based on our croc-hunting adventures, in five days and nights ... in longhand...") and in 'The lizard-skinner' in Forty Yarns, where 'The wayfarer', 'Garth' and 'Rum Jungle Jim' are also set in Australia, as are 'Chelsea's boat', 'A bit of a break', 'A clean swap' and 'Overheard in the pub' in Warm Beer and Other Stories. Hogg Loose Strides pp. 88-90 (with two extracts) calls this "a notebook novel". Crump evidently incorporated material by Blumenthals, who wrote to Reeds in 1973 asking for the return of his manuscript titled 'Latvian crocodile hunter in Australia' and photos which "Mr B. Crump obtained ... from me with intentions to publish with your publishing company" (ATL MS-Papers-6548; Hogg Loose Strides p. 134).

\section{Later printings:}

US edition 1964: San Francisco: Tri-Ocean Books [1964]. 172pp., ill.; 230 cm. Unseen; in Library of Congress catalogue.

Reprint in omnibus 1987: Included in A Barry Crump Collection.

New edition 1990 under new title: CROCODILE COUNTRY (GULF). Illustrated by Will Mahony. Opotiki: Barry Crump Associates; 1990. Distributed by Beckett Sterling, Auckland. On verso-title: "First edition (Gulf) 1964 | Reprints numerous | This edition (Crocodile Country) 1990". 192pp., blue wrappers, 206mm. Printed by The Book Printer, Victoria,_Australia. 0959789766. \$19.95.

The text of this edition is unchanged (apart from a few misprints — "a big forked paperback" for "paperbark" at beginning of 'Pruszkowic'; "times" for "time" at beginning of 'Around the Gulf; aboriginal chanting p.150/ 133; "Saxby" for "the Saxby" p.171/152).

New edition 1994. Auckland: Moa Beckett, 1994. Unseen.

New edition 1997: Auckland: Hodder Moa Beckett, 1997. On verso-title: "First edition (Gulf) 1964 | Reprints numerous | This edition (Crocodile Country) 1994 | Reprinted 1997". 192pp., wrappers, 210mm. Printed by McPherson's Printing Group, Australia; offset from 1990 edition, misprints uncorrected. 1869585771. \$24.95. At head of cover: "A New Zealand Classic".

Crump's list in Life and Times gives total sales by Sept. 1991 as 60,000 copies.

A Braille edition was produced in Australia in 1964: Gulf. Annerley, Qld.:

Kōtare 4, no. 2 (2001), pp. 3-160. 
Crump's list in Life and Times gives total sales by Sept. 1991 as 60,000 copies.

A Braille edition was produced in Australia in 1964: Gulf. Annerley, Qld.: Queensland Braille Writing Association. 1964. 3 volumes of interpoint Braille (held by National Library of Australia).

An abridged Russian translation was published in 1969 in a series 'Putechestviia. Prikliucheniia. Fantastika' (Travel, adventure, fantasy): Zaliv. Barri Kramp. Abridged translation by Eleonory Gerzhevich and Dmitriia Zhukova. Drawings by Uilla Meoni. Afterword and notes by V.M. Bakhty. Moscow: Mysl', 1969. 127pp. 200mm. 100,000 copies, price 34 kopeks.

Reed knew nothing of the Russian edition until they received a letter from Bulgarian Svetoslav Kolev asking permission to include an extract from Crump in an anthology of world humour (see under A Good Keen Man). Kolev then sent them his own copy; its location is now unknown but the University of Auckland Library holds a copy. Reed asked Irene Esam of the Russian Dept at Victoria University to translate the introduction and this was done by honours student Philip Saffery, who published an article 'Introduction to and translation of an afterword by V.M. Bakhta to the Russian translation of Barry Crump's Gulf, New Zealand Slavonic Journal 5 (Winter 1970): 25-32.

The Afterword gives information on the author, New Zealand, the Northern Territory of Australia, and the status of the Aborigines: "... For many reasons ... the Kiwi is much closer to nature than we, the Europeans ... and right down to the present day the blood of his ancestors stirs the soul of every New Zealander ... Every Kiwi remains in the depth of his being_an original settler and a pioneer and the books that are so dear to his heart are those in which he recognises himself plunging through the depths of the bush ..." (Saffery's translation). Asked by Reed to comment on this Crump replied: "My only comments on the afterword are that it seems rather a long one. I wouldn't have realised how close to the earth and nature we are by comparison with Europeans, had it not been pointed out in that foreword".

Index Translationum (the cd-rom cumulation, Paris: Unesco, 1994-) records what is apparently a new edition: "Moskva: Tropa, 1992. lv.". Reed tried to obtain royalties from the Russian publishers, without success, as did Crump himself (Life and Times p.131).

The book was broadcast on radio in 13 episodes of approximately $12 \mathrm{~min}$. each, read by Crump (held at Radio NZ sound archive). A film was planned but it "fell through from lack of finance" ('Safari in Ghuznee Street' in Forty Yarns). "We worked together on an adaptation of his novel Gulf...", says John O'Shea (Don't Let it Get You (1ㅡㄴ $)$ p.35) who gives as reasons for the failure of the film the West German co-producers' withdrawal for financial (tax) reasons and an Australian decision to declare crocodiles protected as an endangered species. See also Hogg Loose Strides pp.95, 97.

Kōtare 4, no. 2 (2001), pp. 3-160. 
'With Darcy again', 'Most of the time'.

Extracts reprinted:

Part of 'The Yaloginda Pub' (pp.68-71) with conclusion from 'Goodbye to Yaloginda' (p.143) reprinted as 'Stoneball Jackson' in The Best of Crump. Extract (pp.68-71) from 'The Yaloginda pub' reprinted as 'The art of burying a groper' in Jack Pollard, ed. The Scream of the Reel, Deep-sea, Beach, Estuary and Inland Angling in Australian and New Zealand Waters. Melbourne: Lansdowne Press, 1966. xv,316pp. Pp.23-5. (Also published with A.H. \& A.W. Reed imprint; new edition Lansdowne 1971. 0701801824; paperback edition Sydney: Jack Pollard Publishing 1975; enlarged edition Sydney: Jack Pollard Publishing, 1977.

0867420081. 379pp.; reprinted Dingley, Vic: Budget Books, 1984.0868012963; rev. and enl. 4th ed. Dingley, Vic: Budget Books, 1984. 0868012971.)_

\section{B7. Scrapwaggon 1965}

BARRY CRUMP | [swelled rule] | SCRAPWAGGON | [swelled rule] | illustrated by | ROGER HART | [publisher's device] | A. H. \& A. W. REED | WELLINGTON - AUCKLAND - SYDNEY

"First published 1965" (verso-title). 158pp., brown boards, 223mm; fawn dustjacket. Printed by Halstead Press, Sydney, Australia. 16s.

Novel; written in shed on Jack Lasenby's section (Lasenby Tribute p.58). Originally titled 'Give a Bloke a Yard', reluctantly published by Reed after considerable reworking (ATL MS-Papers-6548); Hogg Loose Strides pp.91, 93-6 (with extract).

\section{Later printings:}

2nd impression October 1965: "First published June 1965 | Reprinted October 1965"; otherwise as preceding.

3rd impression March 1966: "... Reprinted October, 1965, March, 1966"; otherwise as preceding.

New edition 1985: [Auckland]: Beckett [1985]. 158pp., orange wrappers. 210mm. "First Beckett edition 1985. Printing through Communication Arts Ltd." 0908676751 (on back cover as: 0-908-676-71-1). \$14.95. Title on cover is Scrap zvaggon.

New edition 1997: Auckland: Hodder Moa Beckett, 1997. On verso-title: "First published in 1985 [sic] by Beckett Publishing | This edition published in 1997". 158pp., wrappers, 210mm. Typeset by TTS Jazz, Auckland; printed by Wright and Carman (NZ) Ltd. 1869585429. \$24.95. At head of cover: "A New Zealand Classic". 
and Carman (NZ) Ltd. 1869585429. \$24.95. At head of cover: "A New Zealand Classic".

Crump's list in Life and Times gives total sales by Sept. 1991 as 25,000 copies.

A sound recording for the blind was made in 1987: Scrapwaggon. Read by Christian Stafford. Auckland: Royal New Zealand Foundation for the Blind, 1987.1 sound cassette (3 hrs).

A 60 minute television adaptation was planned by TV2 in 1976 but nothing came of the venture (ATL MS-Papers-6548: 20.7.76, 9.2.77).

Chapter titles: 'Give a man a yard...', 'Preamble', 'Scrapwaggon', 'One for a jack', 'Reorganisation', 'Non-ferrous', 'Made men', 'Felicitations', 'In the spring', 'Injunction'.

Extracts reprinted:

'Give a man a yard...' and 'Preamble' (omitting first page) reprinted as 'Give a man a yard' in The Best of Crump.

B8. The Odd Spot of Bother 1967

BARRY CRUMP | [double rule] | THE ODD | SPOT | OF BOTHER | [row of five large solid black dots] | [double rule] | Illustrated by John Crawley | [publisher's device] |A. H. \& A. W. REED | Wellington - Auckland - Sydney

"First published 1967" (verso-title). 159pp., red boards, 223mm; white dustjacket. Printed by Halstead Press, Sydney, Australia. \$1.85.

Novel, hurriedly written after Reed initially rejected his short story collection (B9): Hogg Loose Strides pp.99-101, 105. The contract for the book dated 13.10.67 paid an advance of $\$ 2000$ (ATL MS-Papers-6548). "I [wrote] it in order to pay off several thousand dollars, $\$ 3800$ actually, that the Inland Revenue Department and I discovered I owed them..." (Sunday News 3 lune 1973: 27; H67).

\section{Later printings:}

2nd impression: "First published November 1967 | Reprinted December 1967"; otherwise as preceding.

3rd impression: "... | Reprinted February 1968"; otherwise as preceding. New edition 1997: Auckland: Hodder Moa Beckett, 1997. 160pp., wrappers, 210mm. Typeset by TTS lazz, Auckland; printed by Wright and Carman (NZ) Ltd. 1869585437. \$24.95. At head of cover: "A New Zealand Classic". 
by Karl Bradley. Auckland: Royal New Zealand Foundation for the Blind, 1976. 1 sound cassette (3 hrs, $45 \mathrm{~min}$.).

Chapter titles: 'A long story', 'A bit of a lean spell', 'The odd spot of bother', 'The same sort of trouble' [incorporating a story 'Bill goat': $\underline{\text { A6] }}$, 'A change of luck', 'High finance', 'Money no object', 'Financial hazards', 'Not negotiable', 'A man of substance'.

\section{Extracts reprinted:}

Second half of 'Financial hazards' and all of 'Not negotiable' reprinted as 'Financial hazards' in The Best of Crump.

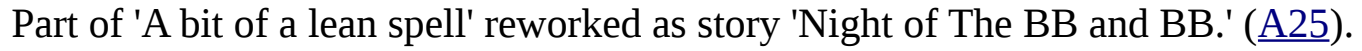

B9. Warm Beer and Other Stories 1969

[all set left:] WARM BEER | AND OTHER STORIES | by BARRY CRUMP | Illustrated by | TONY STONES | [publisher's device] A. H. \& A. W. REED | WELLINGTON AUCKLAND SYDNEY MELBOURNE

"First published 1969" (verso-title). 183pp., orange boards, 223mm; red and white dust-jacket. Typeset by Commercial Print Ltd., Wellington and printed offset by Dai Nippon Printing Co., (International) Ltd. [Hong Kong]. SBN: 589 00405 0. \$2.25.

Short stories: "Barry Crump's eighth title ... his first published collection of short stories" — dust-jacket flap. Reluctantly published by Reeds after initial rejection and much editing. Hogg Loose Strides pp. 91-3 (with extract), 107-8.

\section{Later printings:}

2nd impression 1970: "First published 1969 | Reprinted 1970"; otherwise as preceding.

New edition 1997: Auckland: Hodder Moa Beckett, 1997. 183pp., wrappers, 209mm. (Typeset by TTS Jazz, Auckland; printed by Wright \& Carman (NZ) Ltd). 186958550X. \$24.95. At head of cover: "A New Zealand Classic".

The dust-jacket flap of Fred proclaims that Warm Beer "sold over 10,000 copies within 10 days of publication with some of the stories being acclaimed as the best short stories ever written"; and according to the dust-jacket of Hang On a Minute Mate, 1970 edition, it "sold its first printing of 10,000 copies in less than a week, just before Christmas 1969". Crump's list in Life and Times gives total sales by Sept. 1991 as 10,000 copies. A sound recording for the blind was made in 1973: Warm Beer and Other Stories. Read by Craig Little. Auckland: Royal New Zealand Foundation_for the Blind, 1973.1 sound cassette (4 hrs). 'Lawful excuse' 
Warm Beer and Other Stories. Read by Craig Little. Auckland: Royal New Zealand Foundation_for the Blind, 1973.1 sound cassette (4 hrs). 'Lawful excuse' was filmed in 1976 (1ㅡ).

Contents: 'Crossed wires'; 'Double scotch'; 'Chelsea's boat'; 'Lawful excuse'; 'Twice bitten' [revised from longer version in NZ Listener 1964: A7]; 'A bit of a break' [slightly revised from earlier version in NZ Listener 1964: A4]; 'Trap'; 'Sewing-machine'; 'Taxi' [in Contents listed as 'Taxi!']; 'His just deserts [sic] (Mrs Mobberley's story as told to Jeremy Cosgrove)'; 'A clean swap'; 'Wharf-and-rail'; 'Flower arrangement'; 'A stroke of luck'; 'Overheard in the pub' [earlier version, set New Zealand, as 'The wonderful West Coast sand mullet' NZ Listener 1965: A8]; 'Hot stuff; 'That way' [earlier versions in Otago University Review 1963 and Man 1965: 스];; 'Horseplay'; 'Warm beer'.

('Chelsea's boat', 'A bit of a break', 'A clean swap' and 'Overheard in the pub' are set in Australia.).

\section{Extracts reprinted:}

'Taxi' incorporated into "No Reference Intended" as Chapter 3 'With an axe' (slight changes: "Mobberley" changed to "Mobberly" except at beginning; two extra sentences after "woolsheds?" p.46/p.76; "rummaged" for "fumbled" p.48/p.79; name on letterbox differs p.51/p.81; "Or could it?" added at end).

'His just deserts' incorporated into "No Reference Intended" as Chapter 6 'Cosgrove uppermost' (pp.112-21; slight changes).

'That way' reprinted as 'Warm beer and other stories' in The Best of Crump. 'Overheard in the pub', 'Horseplay', 'Warm beer', 'A clean swap', 'Crossed wires' (with slight changes), 'Wharf-and-rail', 'A stroke of luck', 'Hot stuff, 'Flower arrangement' (as 'Separate rooms'), 'Taxi' (as 'Country Correspondent'; with "fumbled" as in "No Reference Intended"), 'His just deserts' (as 'Just desserts'), 'That way', 'Double scotch', 'A bit of a break', 'Sewing-machine', 'Lawful excuse', 'Trap' and 'Twice bitten' reprinted in Barry Crump's Bedtime Yarns.

'Warm beer' reprinted as 'A dinkum ghosf in Jim Henderson, ed. Return to Open Country, People and Places Out of Town. Illustrated by David Cowie. Wellington: A.H. \& A.W. Reed, 1967. 250pp. Pp.89-93 (reprinted 1971, 1975 with ISBN 0589003062).

'Lawful excuse' reprinted in Bill Lennox, Film and Fiction, Studies of New Zealand Fiction and Film Adaptations. Auckland: Longman Paul, 1985. xv,152pp (0582857104). Pp.10-16 (with discussion of the film 'A Lawful Excuse' pp.1-9).

'His just deserts' is reprinted as autobiographical in Hogg Loose Strides pp.19-24 and 'That way' is reprinted pp.172-8 as background to Crump shooting his dog in 1988. 
6548.

'Warm beer' was translated as 'Warmes Bier' by Frank Auerbach in Frank Auerbach, ed. Letztes Abenteuer und andere neuseelandische Erzahlungen. [Tubingen \& Basel]: Horst Erdmann Verlag, (c) 1972. 410pp. 3771107652. Pp.166-71 (reissue? with new title: Letztes Abenteuer, Neuseeland in Erzahlungen der besten zeitgenossischen Autoren and altered dust-jacket, (C) 1972. 3771107660).

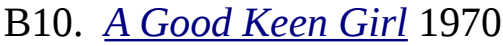

A Good Keen Girl | Barry Crump | Illustrated by Tony Stones | [publisher's device] |A. H. \& A. W. REED | WELLINGTON AUCKLAND SYDNEY MELBOURNE

"First published 1970" (verso-title). 155pp., pale blue boards, 219mm; multicoloured dust-jacket with blue background. Typeset by Commercial Print Ltd., Wellington; Printed by Dai Nippon Printing Co. (International) Ltd., Hong Kong. 0589004956. \$2.25. The "Author's Note" on p.5 is printed in reverse (mirror printing).

Novel. Lengthened at the request of Reeds, who preferred the title 'A Good Keen Woman' to match A Good Keen Man. A Reed memo states that the illustrations are a collaboration by Tony and Cushla Stones, and a letter from Crump to Reeds of 2.4.70 (both ATL MS-Papers-6548) expresses his approval of the illustrations: "In my opinion they capture the atmosphere of the book superbly; better than any of the others have done to date, including Dennis Turner's excellent efforts", querying only a depiction of the wrong type of saw in chapter 11 . Hogg Loose Strides pp.114-7 (with extracts), 119,125.

Later printings:

Reprint in omnibus 1987: Included in A Barry Crump Collection, 1987.

New edition 1997: Auckland: Hodder Moa Beckett, 1997. 156pp., wrap_pers, 209mm. Typeset by TTS, Jazz, Auckland; printed by Wright and Carman (NZ) Ltd. 1869585453. \$24.95. At head of cover: "A New Zealand Classic".

Crump's list in Life and Times gives total sales by Sept. 1991 as 25,000 copies. Reed reported to Crump in 1972 that some 10,000 were unsold. A sound recording for the blind was made in 1970: A Good Keen Girl. Read by Don Farr. Auckland: Royal New Zealand Foundation for the Blind, 1975. 1 sound cassette (3 hrs, 15 min.).

Chapter titles: 'The Blackrange Station', 'The old red bull', 'Bert', 'Herepo', 'A spell away', 'Bendy and ugly', 'A good keen girl', 'Affectional associations', 'A great start', 'The mistress of Blackrange Station', 'Critical trends', 'Very

Kōtare 4, no. 2 (2001), pp. 3-160. 
great start', 'The mistress of Blackrange Station', 'Critical trends', 'Very

unpleasant', 'Psychology versus astrology', 'Faith in the future'.

Extracts reprinted:

'Bert', first part of 'Affectional associations', and 'Critical trends' reprinted as 'Bert' in The Best of Crump.

B11. "No Reference Intended" 1971

"NO REFERENCE | INTENDED" | BARRY CRUMP | [publisher's device] | A.H. \& A.W. REED | WELLINGTON/AUCKLAND/SYDNEY/MELBOURNE

"First published 1971" (verso-title). 164pp., orange boards, 221mm; orange dustjacket. Eleven line drawings by Tony Stones. Typeset by Typemasters (N.Z.) Ltd., Auckland; printed by Dai Nippon Printing Co. (International) Ltd., Hong Kong. 0589006452. \$2.25. A note on the dust-jacket front flap states "Jacket design by Tony and Cushla Stones" but a Reed memo in ATL (MS-Papers-6548) corrects this: it is by Tony Stones only (though they did collaborate on A Good Keen Girl).

Novel. Written before A Good Keen Girl but publication postponed by Reed who were unhappy with the book. A memo of 24.7 .70 notes some changes by Reed editors - the circulation figure of the newspaper upped from 600 to 6,000; 'bugger' changed to 'sod' (ATL MS-Papers-6548). Hogg Loose Strides pp.96, 114, 119-20 (with extract). A satire on journalists, motivated in part by Crump's experiences after his 1964 shipwreck in_Australia (Ivan Agnew, Sunday News 3 June 1973: 24; $\underline{\text { H67)}}$.

\section{Later printing:}

New edition 1997. Auckland: Hodder Moa Beckett, 1997. 164pp., wrappers, 209mm. Typeset by TTS Jazz, Auckland; printed by Wright and Carman (NZ) Ltd. 1869585445. \$24.95. At head of cover: "A New Zealand Classic".

Crump's list in Life and Times gives total sales by Sept. 1991 as 10,000 copies.

A sound recording for the blind was made in 1975: No Reference Intended. Read by Don Farr. Auckland: Royal New Zealand Foundation for the Blind, 1975. 1 sound cassette (4 hrs).

Chapter titles: 'Lowdown on Cosgrove', 'Landscape with Cosgrove', 'With an axe' [reprint of 'Taxi' in Warm Beer and Other Stories, with slight changes listed there], 'With imagination', 'Cosgrove undone' [incorporates 'His just deserts' from Warm Beer and Other Stories], 'Cosgrove uppermost', 'Desperate measures', 'Not for publication', 'Cosgrove triumphant'.

Kōtare 4, no. 2 (2001), pp. 3-160. 
First half of 'With an axe' reprinted in David Hill \& Elizabeth Smither, ed. The Seventies Connection. Dunedin: John McIndoe, 1980. 208pp. 0868680265. Pp.148-51 (an anthology offering "an extremely wide range and variety of contemporary New Zealand writing").

Most of 'With an Axe' (pp.40-51, omitting first and last page) reprinted in Frank Muir, ed. The Oxford Book of Humorous Prose, from William Caxton to P.G. Wodehouse. A Conducted Tour. Oxford: Oxford University Press, 1990. xxxiv,1162pp. 0192141066. Pp.770-7. (reprint in paperback 1992. 0192829599); brief introduction to the story by Muir p.770: "...The humour in his first books tended to be somewhat manic, but by his tenth ... Crump's style had calmed down and his humour sprang from character and a fine ear for the terse, lean speech of New Zealand countrymen...".

\section{B12. Bastards I Have Met 1971}

Bastards I Have Met | An ABC of Bastardry | BY | BARRY CRUMP | CRUMP PRODUCTIONS LTD. | P.O. Box 5090, Auckland.

Page number "3" at foot of title-page.

"C Barry Crump 1971" (p.2). 152pp., grey boards, 219mm.; brown and red dustjacket. Set and printed by Business Printing Works Ltd, Auckland. 41 black \& white illustrations by Garth Tapper and pictorial endpapers and dust-jacket. \$3.

Extracts were published in the Sunday News before publication, "specially edited" with some material not in the book (front page announcement 21 Nov. 1971: 1; interview on the book 28 Nov.; extracts in the issues for 5 Dec. (pp.46-7: 'Meet a clever bastard'); 12 Dec. (pp.46-7: 'What a dozey bastard!', 'A real bright bastard', 'Meet a jovial bastard'); 19 Dec. (pp.42-3: 'He's a puzzly bastard'); $\underline{\text { H58). }}$ ).

Short stories / character sketches - "An informal encyclopaedia of some of the types of Bastard you run into these days, complete with ungarnished reports of the author's personal encounters with them ..." (p.4). Published by Crump himself ("my mate John Brown and I established our own publishing company": Sunday News 20 May 1973: 37) after Reeds declined it. "I wrote a book and had it printed and published it myself, as much for the challenge of it as anything else ... it sold out in two weeks and for the first time in my life I had some real cash in my kick...": Life and Times p.130. The NZ Herald 30 Dec. 1971: 3 reported under the headline 'Good keen man defies publishers and makes it alone': "Crump ... intends to be a publish it yourself author ... A two week selling campaign in December saw the 10,000 copies of the first printing sold. The printers came up with another 2,000 copies at a week's notice and they were promptly sold too...". This second printing has not been identified. Crump's list in Life and Times gives total sales by Sept. 1991 as 145,000 copies. Hogg Loose Strides pp. 121-4 (with extract), 126,129. The NZBC refused to allow Crump to be interviewed about the book and the following year the Australian Broadcasting Control Board imposed

Kōtare 4, no. 2 (2001), pp. 3-160. 
book and the following year the Australian Broadcasting Control Board imposed strict limits on advertising it on Australian television.

Later printings:

Australian (paperback) edition 1972: Melbourne: Gold Star Publications (C1972. 152pp., black wrappers, 183mm. Printed by Spendlove Pty, Burnley, Victoria; offset from 1971 edition. A \$1.95.

New (enlarged) edition 1986: Auckland: Beckett, 1986. "First Beckett edition 1986". 186pp., blue wrappers; 210mm. "Printing through Communication Arts Ltd". 0908676026. \$16.95.

This edition adds "another eight unlikely Bastards..." (back cover) — in fact seven, all taken from Fred, and there are new illustrations, 33 line drawings by Graham Kirk.

Reprint 1987: "Reprinted March 1987"; otherwise as preceding. New edition 1990: Opotiki: Barry Crump Associates, 1990.186pp., 211mm, blue wrappers. Printed by The Book Printer, Australia; offset from earlier edition. 095978974X.

New edition 1995: Auckland: Hodder Moa Beckett, 1995.186pp., 211mm, wrappers. Printed by McPherson's Printing Group, Australia; offset from earlier edition. 095978974X. \$24.95. At head of cover: "A New Zealand classic".

Reprint: Auckland: Hodder Moa Beckett, 1997. 1869585763; otherwise as preceding.

A Braille edition was produced in 1984: Bastards I Have Met, An ABC of Bastardly. Auckland: Royal New Zealand Foundation for the Blind, 1984. Wellington Braille Club, transcribing agency. 3 volumes of thermoform Braille (Grade 2), and a sound recording for the blind in 1991: Bastards I Have Met. Read by Bill Leathwick. Auckland: Royal New Zealand Foundation for the Blind, 1991. 1 sound cassette (4 hrs, 15 min.).

Contents: 'Actual Bastard', 'Bad Bastard', 'Clever Bastard', 'Dozey Bastard', 'Enigmatic Bastard', 'Filthy Bastard', 'Good Bastard', 'Hard-case Bastard', 'Intellectual Bastard', 'Jovial Bastard', 'Kinky Bastard', 'Lazy Bastard', 'Miserable Bastard', 'Nasty Bastard', 'Officious Bastard', 'Poor Bastard', 'Queer Bastard', 'Rude Bastard', 'Situational Bastard', 'Temperamental Bastard', 'Unlucky Bastard', 'Vain Bastard', 'Weak Bastard', 'Xenial Bastard', 'Young Bastard', 'Zealous Bastard'.

The 1986 edition adds: 'Simple Bastard' [from 'Nobby' in Fred], 'Rough Bastard' ['Scratcher' in Fred], 'Literate Bastard' ['Quentin' in Fred], 'Slow Bastard' ['Weaver' in Fred], 'Useless Bastard' ['Ted' in Fred], 'Indispensable Bastard' ['Joe' in Fred], 'Stupid Bastard' ['Eggy' in Fred].

Kōtare 4, no. 2 (2001), pp. 3-160. 
Extracts reprinted:

'Enigmatic bastard', 'Lazy bastard', 'Poor bastard', 'Queer bastard' are reprinted as 'Bastards I have met' in The Best of Crump with slight changes, possibly by the printer.

Fred 1972

FRED | BY BARRY CRUMP | Illustrated by Howard Baker | Cover Design by Roger Bradley | Published by Crump Productions Ltd, | Auckland, N.Z. | 1972

Page number "ii" at foot of title-page which is a verso (p.i: "Other books by Barry Crump"; p.ii: title-page; p.iii: Copyright notice; p.iv: Dedication; p.v: "Contents"; p.vi: illustration; pp.7-109 text).

vi, 109pp., red (also green, blue) boards, 223mm; black dust-jacket. \$3.00. 17 line drawings by Howard Baker; the "cover design by Roger Bradley" refers to the dust-jacket. The printer is not named but in an interview Crump stated "the book is being printed in Japan" (Hogg Loose Strides p.129).

Novel. Published by Crump himself at the end of 1972. A six part series of extracts appeared in the Sunday News from 24 Dec. 1972. Interview on the book by Anne Marie Nicholson, 'Meet Crump. He's really a nice bunch of chaps', Sunday News 17 Dec. 1972: 33 (ㅌ6). Crump's list in Life and Times gives total sales by Sept. 1991 as 5,000 copies. Hogg Loose Strides pp.129-32 (with extract).

B13.

\section{Later printing:}

New edition: Auckland: Hodder Moa Beckett, 1997. 115pp., wrappers, 209mm. Typeset by TTS Jazz, Auckland; printed by Wright and Carman (NZ) Ltd. 1869585461. \$14.95. At head of cover: "A New Zealand Classic".

Chapter titles: 'Fred', 'Cubby', 'Tangaroa', 'Nobby', 'Scratcher', 'Quentin', 'Weaver', 'Ted', 'Joe', 'Eggy', 'Jenny', 'The whitebaiters', 'Sam', 'Russell', 'On the town', 'Happily ever after'.

Extracts reprinted:

'Joe', 'Ted' (omitting last paragraph about Ralph Nock), 'Scratcher' (omitting Ralph Nock paragraph p.30) and 'On the town' reprinted in The Best of Crump.

'Nobby' is substantially reprinted as 'Simple bastard', 'Scratcher' as 'Rough bastard', 'Quentin' as 'Literate bastard', 'Weaver' as 'Slow bastard', 'Eggy' as 'Stupid bastard', 'Joe' as 'Indispensable bastard', 'Ted' as 'Useless bastard' in Bastards I Have Met (1986 edition).

B14. The Best of Crump 1974

Kōtare 4, no. 2 (2001), pp. 3-160. 
The Best Of Crump | BY | BARRY CRUMP | CRUMP PRODUCTIONS LTD. | P.O. Box 5090, Auckland

"Copyright (C) 1974 Barry Crump" (p.[ii]). [vi],300pp., green (also blue, red) boards, 220mm; white dust-jacket; illustrations by Dennis Turner, Will Mahony (misspelt 'Mahoney'), Roger Hart, John Crawley, Tony Stones, Garth Tapper, Howard Baker (reproduced from the original publications). "Cover design [i.e. dust-jacket] by Roger Bradley". Set up and printed by Business Printing Works Ltd., Auckland. \$4.95. Title on dust-jacket: THE BEST OF BARRY CRUMP. A prospectus (ATL MS-Papers-6548) gives planned publication date as 1.8.74. Advertised NZ Bookworld 13 (Dec. 1974-Jan. 1975) p.11: "Richly-illustrated and compiled by the author himself ... The first printing of 5,000 copies sold out in two and a half months in the middle of this year ... Wholesale: \$3.20 per copy. Retail: $\$ 4.95$ per copy. Autographed by request. A discount of $10 \%$ will be allowed for cash with your order...". This implies there was a reprint: if so it is not designated as such. Misdated 1970 by Crump in his list in Life and Times (where he gives total sales to Sept. 1991 as 10,000) and by Hogg Loose Strides p.198.

A selection by Crump from all his previous books except "No Reference Intended". 22 illustrations were reproduced from his earlier works for the use of which Reed charged \$7.50 each (\$165).

\section{Contents:}

'Some good keen men' [end of T become a deer culler'; all of 'That healthy outdoor life'; 'Some good keen men', 'I meet Harry', 'I hunt the cocky's pigs with Tim', 'I meet Legs', 'In for my chop', 'Harry again', 'Two prize heads', 'Wilmer' from A Good Keen Man];

'Sam Cash' ['Sam', 'Jack', 'The Pahau Valley pub', 'Not guilty, sir', 'The unluckiest bloke on earth', 'The muster', and part (pp.37-42) of 'No sense of humour' from Hang on a Minute Mate];

'Shai's yarn' ['Shai's yarn', 'Dan's yarn', end of 'Hospitality', most of 'Toddy' (omitting end), all of 'Toddy in trouble' and 'On contract' from One of Us];

'A shrewd move' ['A shrewd move', 'The Reverend Mister Cash', 'Saddleblanket', 'Shabby dog' and 'It's a he!' from There and Back]; _Stoneball Jackson' [part of 'The Yaloginda Pub', pp.68-71, and conclusion from 'Goodbye to Yaloginda', p.143, from Gulf];

'Give a Man a Yard' [ 'Give a man a yard...' and 'Preamble', omitting first page, from Scrapwaggon];

'Financial hazards' [second half of 'Financial hazards' and all of 'Not negotiable'

Kōtare 4, no. 2 (2001), pp. 3-160. 
from The Odd Spot of Bother];

'Warm beer and other stories' [That way' from Warm beer and other stories];

'Bert' ['Bert', first part of 'Affectional associations' and all of 'Critical trends' from A Good Keen Girl];

'Bastards I have met' ['Enigmatic bastard', 'Lazy bastard', 'Poor bastard', 'Queer bastard' from Bastards 1 Have Met, with slight changes, possibly by the printer];

'Joe' [from Fred].

B15. Shorty 1980

[illustration] | SHORTY | Barry Crump wrote it | [illustration] | rick welland decorated it $\mid \mathrm{CW}$ associates

Page number "7" at foot of title-page.

"First published 1980 | CW associates | Box 21249, Henderson | Auckland, New Zealand." (p.8).

100pp., black wrappers, 207mm; black dust-jacket. "Made and printed in New Zealand by Business Printing Works Ltd". No ISBN. \$9.95.

Humorous story about golf, written on Tapuaetahi in the Cook Islands ("I began to write an article up there for a golf magazine - but it grew and grew to a 45,000-word book": Auckland Star 4 Oct. 1980; $\underline{\text { H84) }}$. The book was offered to Reeds who planned an edition of 10,000 cased followed by a paperback (ATL MS-Papers-6548) but the print-run, royalties and speed of publication were unacceptable to Crump who published it himself in November 1980: "...publishers told Crump the book couldn't be out in time for Christmas ... So Barry, Robyn and the illustrator, American-Rarotongan Rick Welland came back from the Islands and had the book to the printers within two days ..." (Amanda Samuel, NZ Woman's Weekly 8 Dec. 1980: H87); "I'd written a short book while we were in the Cook Islands and Robyn and I published it... three weeks from typescript to the bookshops. I wrote it in about ten days. It may be being made into a_film..." (Life and Times pp.202-3).

Crump says of his wife Robyn (Life and Times p.222): "She's only as big as thruppence. I wrote a book called Shorty once to try and make her see how unimportant being short is" - for Robyn's view see Stacy Gregg. 'When a myth is so hard to beat', Sunday Star Times 8 Dec. 1996: 3 (는) $)$. Crump's original title for the book was 'Don't Call Me Shorty' (Tribute p.179).

In an interview with Phil Gifford ('Crump moves on', Listener 21 Feb. 1981: 1078; H89) Crump "defends the way his central character in Shorty speaks an unusual mixture of slang, varying from the old-fashioned to the disc-jockeyspeak

Kōtare 4, no. 2 (2001), pp. 3-160. 
of 'hassle' and 'blown away'. 'That's the way we're going ... More and more people, the young people especially, are getting into that type of jargon..."'. Hogg Loose Strides pp.147-9.

Crump failed to pay the printer's bill for the book which was eventually settled by Beckett (Tribute pp.160-1). His list in Life and Times gives total sales by Sept. 1991 as 5,000 copies.

For Crump and golf see Amanda Samuel, 'Barry has a new book (and a new view of women)', NZ Woman's Weekly 8 Dec. 1980: 64-5, 67 (ㅂ7); Life and Times pp.130, 203; Tribute pp.132-6,179; Hogg Loose Strides p.134.

\section{Later printings:}

Reprint in omnibus, 1987: Included in A Barry Crump Collection.

New edition 1997: Auckland: Hodder Moa Beckett, 1997. 96pp., green wrappers, 209mm. Typeset by TTS Jazz, Auckland; printed by Wright \&

Carman (NZ) Ltd, New Zealand. 186958547X. \$14.95. At head of cover: "A New Zealand classic".

Chapter titles: 'April', 'May' [revised from 'More golf New Zealand Golf

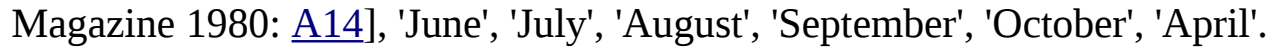

\section{B16. Puha Road 1981}

[all inside frame] PUHA ROAD | By Barry Crump | [illustration: tree] | Illustrated by | Linda Poulton | Published by C \& C Associates

Page number "I" at foot of title-page outside frame. No publication or copyright date in book.

v,[i],142pp., green boards, 211mm; fawn dust-jacket. Typeset and printed_by Business Printing Works Ltd, Auckland; bound by Trade Rule \& Binding Ltd. No ISBN. \$9.95.

Published 1981: accession date of ATL copy is 10.9.81; dated 1982 by Crump Life and Times p.237, Hogg Loose Strides p. 198, and in 1993 and 1996 editions of the book.

Novel. "He wrote Puha Road in 19 days — sitting in the van at the bottom of a quarry at Opononi because the story ends in a quarry ... and he wanted to get the right atmosphere ... 'My wife Robyn gave me the idea ... She doesn't worry about things much, doesn't see much difference between being wealthy or broke - I do. Anyway, Puha Road is about materialism and luck..."' (Auckland Star 4 July 1981; H90); "We drifted to the far north and camped in a disused quarry for two or three weeks while I wrote a book. Got the title off a sign up there. Puha Road.

Kōtare 4, no. 2 (2001), pp. 3-160. 
We took it down to Auckland and got it printed and distributed. Robyn did most of the office-type work connected with it. It sold quite well..." (Life and Times p.201). Crump's list in Life and Times gives total sales by Sept. 1991 as 5,000 copies. See also Tribute p.87; Hogg Loose Strides pp.149, 153-5 (with extracts; he wrongly implies p.153 that it is the first edition rather than the 1993 edition that has the recycled Dennis Turner illustrations).

\section{Later printings:}

Reprint in omnibus 1987: Included in A Barry Crump Collection (without illustrations except for flax bush at beginning; follows text of first edition). New edition 1993: Tauranga: Barry Crump Associates, 1993. Distributed by Becket [sic] Sterling Ltd., Auckland. 192pp., dark brown wrappers, 210mm. Printed by Australian Print Group, Vic. 3465, Australia. On verso-title: "First edition 1982 Reprints nil | This edition 1993". 0908968019. Yellow sticker on cover of copy seen: "Reprinted by Popular Demand". Some minor textual changes, e.g. end of Chapter 1 rephrased, and some additions: middle of chapter 4 (pp.71-3); end of chapter 9 (pp.165-72); paragraph p. 191. In this edition the Linda Poulton illustrations are replaced with eleven adapted and redrawn from those by Dermis Turner in Crump's earlier books: compare pp. [8], [26], [118] with There and Back pp.113, 21,141 and pp.[44], [60], [84], [136] with One of Us pp.39,173,123, and title-page.

New edition 1996: Auckland: Hodder Moa Beckett Ltd, 1996. On verso-title: "First published in 1982 by Barry Crump Associates | This edition_published in 1996". Reprints text of 1993 edition. 175pp., wrappers, 210mm. Typeset by TTS Jazz, Auckland; printed by Griffin Paperbacks, Australia. 1869584597. \$24.95. At head of cover: "A New Zealand Classic".

Chapter titles: 'Muxy's luck', 'The bottom of the barrel', 'The crest of the wave', 'Agreement to purchase', 'Midwinter and Muxworthy Ltd', 'Standard of living', 'The top of the heap', 'Tough at the top', 'Comfortably off, 'Next of kin'.

\section{B17. Mrs Windyflax and the Pungapeople 1983}

\section{First edition 1983. Unseen.}

A poem for children read on Jim Henderson's "Open Country" programme on Radio Pacific and published on demand in photo-copied form. Crump says in Life and Times (pp.216-7): "...we moved on and camped near Punakaiki on the West Coast, where I wrote a longish poem and dedicated it to our listeners on Radio Pacific ... I sent the poem to Jim Henderson to read out to the listeners, and the station got so many requests for copies that they had to tell the people to send two dollars and a self addressed envelope to me and Robyn. By this time we were camped in Golden Bay and there was only one photo-copier ... in Takaka ... we had to do hundreds of copies and it was five pages long ... I don't know how many copies we had to churn out, but I remember that one day we put four hundred two-dollar notes in our bank...". He told a reporter (Dominion 24 Oct. 
1984) that he had "hundreds of requests" for this "bit of madness"; Hogg Loose Strides pp.159-60.

The poem was reprinted, with illustrations by Kerry Emmerson which were probably also in the photo-copied version, in Barry Crump's Bedtime Yarns (1988) and again (with a fourth stanza inserted) in Southern Skies 1993 (1ㅗ)

New edition 1995: Auckland: Hodder Moa Beckett, 1995. "Published 1995 by Hodder Moa Beckett Ltd. ... Typeset by Egan-Reid Ltd., Auckland. Printed through Bookbuilders, Hong Kong". [32]pp. (plus text inside both endpapers), pictorial boards, 215x289mm. 1869581857. \$24.95. Illustrated by Murray Ball.

Crump was interviewed on TV1 Late News 13 Sept. 1995 (11.33pm) on the book; he met the illustrator only at the launching.

Reprint ("limp edition") 1999: Auckland: Hodder Moa Beckett, 1999. "First published in 1995 ... Reprinted in limp edition 1999". 208x282mm. 1869587693. \$14.95; otherwise as preceding.

B18. The Adventures of Sam Cash 1985

THE | ADVENTURES | OF | SAM CASH | BARRY CRUMP | Illustrated by | Dennis Turner | [illustration] | [publisher's device] | BECKETT

On verso-title: "Published by Beckett Publishing | 28 Poland Road, Glenfield, Auckland, New Zealand | First Beckett edition 1985 | This collection (C Barry Crump 1985...". 281pp., maroon boards, 223mm; red dust-jacket. Production and design by Shoal Bay Press; typeset by Sabagraphics Ltd, Christchurch; printing through Communication Arts Ltd. 0908676506. \$24.95.

Also issued in red wrappers (same design as dust-jacket), 212mm. \$14.95; otherwise as preceding (including ISBN).

A "selection of the best of the Sam Cash stories" (dust-jacket) from Hang on a minute mate and There and back.

\section{Later printing:}

New edition 1997: Auckland: Hodder Moa Beckett, 1997. "First published in 1985 by Beckett Publishing | This edition published in 1997". 280pp., green wrappers, 208mm. Typeset by TTS lazz, Auckland; printed by Griffin Paperbacks, Australia. 1869585488. \$24.95. At head of cover: "A New Zealand Classic".

Crump's list in Life and Times gives total sales by Sept. 1991 as 10,000 copies.

A sound recording for the blind was produced in 1986: The Adventures of Sam Cash. Read by Rob layne. Auckland: Royal New Zealand Foundation for the

Kōtare 4, no. 2 (2001), pp. 3-160. 
Blind, 1986. 2 sound cassettes (6 hrs, 30 min.), and a Braille edition in 1987: The Adventures of Sam Cash. Auckland: Royal New Zealand Foundation for the Blind, 1987. Wellington Braille Club, transcribing agency. 5 volumes of thermoform Braille (Grade 2).

Contents: 'Sam', 'Jack', 'A tidy heap', 'No sense of humour', 'A bunch of brumbies', 'Harvey Wilson's run', 'The muster', 'The Pahau Valley pub', 'Uncle Wally', 'Hard grafting', 'Not guilty, sir', 'Women!', 'Mrs Wagner', 'The way the truck turns', 'Sorry, mate', 'Hang on a minute mate' [all from Hang on a minute mate], and 'Nine bob an hour', 'Nine and six an hour', 'You never know', 'A shrewd move', 'Old hammergun', 'Nothing but the best', 'A line of bull', 'Peter Atkins's pigs' ["Atkins"' in Contents], 'The Reverend Mr Cash', 'Sam Cash, M.P.', 'Saddleblanket', 'Shabby dog', 'Six of one', 'Somewhere quiet for the off-season', 'Hokonui Hank', 'Home' [all from There and Back].

\section{B19. Wild Pork and Watercress 1986}

\section{BARRY CRUMP | Illustrated by | Malcolm Evans | [illustration] | BECKETT | [publisher's device] | PUBLISHING}

The title of the book is omitted from the title-page (p.[5]) and printed at the head of the Contents page (p.[7]).

On verso-title (p.[6]): "Published by Beckett Publishing | 28 Poland Road, Glenfield, Auckland, New Zealand | First Beckett edition 1986". 163pp., dark brown wrappers, 210mm. Typeset by Saba Graphics Ltd., Christchurch; printing through the Book Printer, Australia. 0908676093. \$17.95. Some copies were bound in brown boards (in dark brown dust jacket with text as on paperback wrappers and same ISBN): these were reputedly not sold publicly but supplied to those attending the elaborate launching party for the book (see $\underline{\mathrm{H} 128}, \underline{\mathrm{H} 129}$; Hogg Loose Strides pp.164-6; Tribute p.162); copies bound in pigskin were presented to Crump and to Lloyd Scott.

An agreement between Crump and Beckett Books dated 25 Sept. 1986 (ATL MSPapers-6548) provided for publication to be in November 1986 with a \$3,300 advance to Crump's Kamikaze Productions and a $12.5 \%$ royalty on retail sales. The book was published on November 17, with extracts in the Sunday Star Nov. 91986 (taken from throughout the book; at the beginning the text reads "I was born in 1982" whereas the book has "1974") and in the Auckland Star "to coincide with publication". "The entire print run of 12,500 copies sold out within three days of publication..." (NZ Herald 29 Nov. 1986) and it had sold 36,000 copies by February $\{N Z$ _ Herald 26 Feb. 1987; H135). Crump's list in Life and Times gives total sales by Sept. 1991 as 95,000 copies; he told a reporter 100,000 in 1990 (Hogg Loose Strides p.192). See Hogg pp.163-8 ("...Crump's masterpiece ... reminiscent of ... Man Alone, but the characters and the detail are all Crump's..."). 


\section{Later printings:}

Reprint November 1986: Auckland: Beckett Publishing, 1986. Title-page reset to include title and page numbers added in contents. On verso-title: "First edition 1986 | First reprint November 1986". 163pp., dark brown wrappers, 210mm. "Production and design by Shoal Bay Press. Typeset by Saba Graphics Ltd., Christchurch. Printing through Communication Arts Ltd". 0908676093.

Reprint January 1987: "First edition 1986 | Second Reprint January 1987"; otherwise as preceding.

Reprint May 1988: ".. .3rd printing May 1988"; printed by The Book Printer, Australia; otherwise as preceding.

New edition 1995: Auckland: Hodder Moa Beckett, 1995. Unseen: details probably as 1997 reprint.

Reprint 1997: WILDPORK [sic] AND WATERCRESS. Illustrated by Malcolm Evans. 163pp., black wrappers, 210mm; (on verso-title: "First published in 1986 by Barry Crump Associates [sic] | This edition published in 1995 | Reprinted in 1997". Printed by McPherson's Printing Group, Australia; offset from earlier edition. 1869585755. \$24.95. At head of cover: "A New Zealand Classic". In this edition "Wild Pork" is spelt as one word on the title-page and half-title, as two words on the covers.

Novel set in the Urewera country, originally to be titled 'The Scavengers' (unsourced quotation in Hogg Loose Strides p.160), then 'The Wife's Sister's Boy' (the title of Chapter 1).

Chapter titles: 'The wife's sister's boy', 'A dog like Zag', 'Other people', 'A tin of peaches', 'Broken-foot Camp', 'A friend', 'Serious trouble', 'Another notch', 'Six months', 'Okay', 'Epitaph'.

\section{Extracts reprinted:}

Beginning of Chapter 2 reprinted in Gwen Gawith, ed. Falling off the Edge of the 'World: New Zealand Stories. Auckland: Penguin Books, 1991. 228pp.

014014479X. Pp.193-6.

Reviewed by Betty Gilderdale NZ Herald 20 July 1991, calling Crump's piece "sombre in mood".

A sound recording for the blind was made in 1987: Wild Pork and Watercress. Read by John Davies. Auckland: Royal New Zealand Foundation for the Blind, 1987. 1 sound cassette ( 4 hrs, 30 min.).

A film was planned but Crump was unhappy with the screenplays and it never

Kōtare 4, no. 2 (2001), pp. 3-160. 
went ahead (Crump letter in Tribute p.183; Hogg Loose Strides pp.179, 182,191).

A Barry Crump Collection 1987

A BARRY CRUMP | COLLECTION | by | BARRY CRUMP | BECKETT | [publisher's device] | PUBLISHING

On verso-title: "This collection (C) Barry Crump 1987 | Published by Beckett Publishing | 28 Poland Road, Glenfield, Auckland, New Zealand. | First Beckett edition 1987". 382pp., blue wrappers, 211mm. "Printing through Communication Arts Ltd". 0908676263. \$24.95.

B20.

An omnibus reprint of Gulf A Good Keen Girl, Shorty and Puha Road, with one illustration per title.

Later printing:

"First reprint August 1987"; otherwise as preceding.

Crump's list in Life and Times gives total sales by Sept. 1991 as 5,000 copies.

Humble Abodes 1988

BARRY CRUMP'S HUMBLE ABODES CALENDAR 1989. (C) 1988 SeTo Publishing Ltd, Auckland.

B21. A4 size. 12 colour plates from photographs by Crump. The photographs are of tumble-down houses, cottages and huts, plus a cover photo of Crump.

Crump Life and Times p.221 and letter in Tribute p.186; Hogg Loose Strides pp.162; 180 (put together by Crump and Craig Howan, "and they sell the lot"). A copy is held in the ATL ephemera collection.

B22. Barry Crump's Bedtime Yarns 1988

BARRY CRUMP'S | BEDTIME YARNS | BARRY CRUMP'S BEDTIME YARNS | A Collection of Short Stories and poems | compiled and edited by Mandy Herron.

Page number "1" at foot of title-page.

"... Published by Barry Crump Associates Ltd | Copyright (C) Barry Crump ..."(p.4).

226pp., green boards, 211mm. Illustrations by Linda Poulton, Tony Stones, Dennis Turner, Kerry Emmerson. Typeset by Typeset Graphics Ltd; printed by

Kōtare 4, no. 2 (2001), pp. 3-160. 
Business Printing Group Ltd, Auckland. 0959789707. \$24.95.

"A Collection of Stories and Poems by New Zealand's Leading Author" (dustjacket); "The first time Crump's poetry has been offered to the public" (dustjacket flap). The stories all previously published, the poems here first published except for 'Mrs Windyflax and the Pungapeople' (B17).

Crump's list in Life and Times gives total sales by Sept. 1991 as 10,000 copies. A Reed memo of 15.2.89 (ATL MS-Papers 6548) noted that Business Print were holding copies till the bill was paid.

Contents: 'Overheard in the pub', 'Horseplay', 'Warm beer' [stories, from Warm Beer and Other Stories], 'Journey' (poem), 'A clean swap' [story, from Warm Beer and Other Stories], 'Toms [sic] yarn' [story, 'Shai's yarn' from One of Us], 'Dan's luck' [story, 'Dan's yarn' from One of Us, omitting end], 'Crossed wires' [story, from Warm Beer and Other Stories, with slight changes], 'Letter to the I.R.D.' (poem), 'Wharf-and-rail', 'A stroke of luck', 'Hot stuff [stories, from Warm Beer and Other Stories], 'Separate rooms' [story, 'Flower arrangement' from Warm Beer and Other Stories], 'Battle' (poem), 'Country correspondent' [story, 'Taxi' from Warm Beer and Other Stories; this version has "Mobberley" and the other points of 'Taxi' except for "fumbled" as in 'With an axe': see B9] ], 'Just desserts', 'That way' [stories, 'His just deserts' and 'That way' from Warm Beer and Other Stories], 'Cave' (poem), 'Double scotch', 'A bit of a break', 'Sewingmachine' [stories, from Warm Beer and Other Stories], 'Mrs Windyflax and the Pungapeople' [poem, first published in photocopy 1983 (B17); stanza 4 omitted here and other slight changes; reprinted in Southern Skies 1993 (1ㅡ); reprinted as a book with new illustrations by Murray Ball 1995],_Lawful excuse', 'Trap' [stories, from Warm Beer and Other Stories], 'Harry's piece of pain' (poem), 'Twice bitten' [story, from Warm Beer and Other Stories], 'Time of day' (poem).

Later printings:

New edition 1997: Auckland: Hodder Moa Beckett, 1997. 227pp., 209mm. Typeset by TTS Jazz, Auckland; printed by Wright and Carman (NZ) Ltd. 1869585496. \$24.95. At head of cover: "A New Zealand Classic". This edition omits a note 'Happy Reading' on p.3 of the 1988 edition and 'Just desserts' is spelt 'Just deserts' as in its original appearance.

\section{Extracts reprinted:}

'Letter to the I.R.D.' reprinted in Southern Skies 1994 (A21), in Forty Yarns (with prose introduction) and in Song of a Drifter and Other Ballads. 'Battle' reprinted in Life and Times with first two stanzas reversed. 'Journey' (with several changes), 'Time of day', 'Cave' (one change), 'Battle' ("maori" capitalised), 'Harry's piece of pain' (dash for semi-colon in penultimate stanza) reprinted in Song of a Drifter and Other Ballads.

B23. Bullock Creek 1989

Kōtare 4, no. 2 (2001), pp. 3-160. 
BULLOCK CREEK | BARRY CRUMP | Illustrated by Kerry Emmerson | [publisher's device] | BARRY CRUMP ASSOCIATES

On verso-title: "Published by Barry Crump Associates Ltd | Copyright @ Barry Crump ... Distributed by Beckett Sterling Ltd...". 187pp., white wrappers, 210mm. Typeset by Typeset Graphics Ltd., Auckland; printed by The Book Printer, Victoria, Australia. 0959789715. \$19.95. No date in book; published July 1989. The text ends on p.185, p.186 is blank with biographical note on Crump p. 187.

Novel. Crump says in Life and Times ( p.221): "... I did a stint as cook for a merino mustering-gang in Otago and wrote a book called Bullock Creek. With the money from that book I bought the eleven-acre block next to mine..."; Hogg Loose Strides pp.180-1 ("classic old country Crump"). The initial print run was 30,000 copies and Crump's list in Life and Times gives total sales by Sept. 1991 as 30,000 copies. There was an elaborate launching party for the book in the Opotiki backblocks (see $\underline{\mathrm{H} 149}$ ).

Later printings:

Reprint 1993: Tauranga: Barry Crump Associates, 1993. [2],185pp., white wrappers (redesigned); on verso-title: "First edition 1989 | Reprints | This edition 1993 ... Printed by Australian Print Group". 0908968027. Preliminary pages reset, biographical note extended and moved to unnumbered page preceding p.l.

New edition 1996: Auckland: Hodder Moa Beckett, 1996. 175pp., wrappers, 210mm. Typeset by TTS Jazz, Auckland; printed by Griffin Paperbacks, Australia. 1869584643. \$24.95. At head of cover: "A New Zealand Classic". Only change in text noticed is "raining steadily" for "raining steady" beginning of Chapter 5.

A sound recording for the blind was made in 1990: Bullock Creek. Read by Bill Leathwick. Auckland: Royal New Zealand Foundation for the Blind, 1990. 1 sound cassette (10 hrs).

Chapter titles: 'Mutton and spuds', 'The dog', 'Woolgathering', 'A merry dance', 'Over the top', 'The winter', 'The holding-paddock gatepost', 'The wandering wethers', 'A fair price', 'The thaw', 'Showdown at Bullock Creek', 'Miracle at Bullock Creek'.

\section{Extract reprinted:}

The first three paragraphs of the book, with comprehension questions, are included in an online "Reading Comprehensions" series by Mark Osborne, available at <http://www.geocities.com/Athens/Aegean/9366/comps/yr9crump.htm> 
("Copyright 1999. Last Updated 6 February 2000"; viewed 20.9.01).

The Life and Times of a Good Keen Man 1992

BARRY CRUMP | THE LIFE | AND TIMES | OF A GOOD KEEN MAN | THE FIRST OF A TRILOGY | [publisher's device: BARRY CRUMP ASSOCIATES]

On verso-title: "Published by Barry Crump Associates | PO Box 137, Opotiki, New Zealand | Copyright Barry Crump | First edition 1992 | Distributed by Beckett Sterling Ltd. | 28 Poland Road, Glenfield, Auckland, New Zealand.". 237pp (including 48 pages of monochrome photographs), black boards, 238mm; black dust-jacket. Typeset by Typeset Graph-_ics, Auckland; printed by Australian Print Group, Maryborough, Vic, Australia). 0959789774. \$39.95.

The cover title is: "Barry Crump: The Life and Times of a Good Keen Man".

Autobiography: "'The way I seen it' by Barry Crump" (p.5); "It'll be one strand of the rope", said Crump in a 1990 television interview (Magic Kiwis 3 Aug. 1990; H157); "as much as I'm prepared to tell about me", quoted Hogg Loose Strides p.182, who calls the book (p.7) "his evasive, friendless autobiography". Published 8 July 1992, initial printing of 45,000 copies of which 15,000 were presold to shops (see H166-H168). The second part of the trilogy was Forty Yarns and a Song and the third Crutnpy's Campfire Companion.

On pp.52-3 Crump reprints his poem 'Battle' [from Barry Crump's Bedtime Yarns; here with first two stanzas reversed; later reprinted in Song of a Drifter and Other Ballads]; the poem 'Song of a drifter' pp.233-4 is here first printed (reprinted in Forty Yarns and a Song and in Song of a Drifter and Other Ballads; separate printing with music by David Hamilton, 1999).

\section{Later printing:}

New edition 1996: [Auckland]: Hodder Moa Beckett, [1996]. 191pp., plus 16pp of plates, wrappers, 215mm. On verso-title: "First published in 1992 by Barry Crump Associates | Reprinted in 1996". Typeset by TTS Jazz, Auckland; printed by Wright \& Carman (NZ) Ltd, Upper Hutt. 1869583973 (corrected by National Library of New Zealand to -72). \$24.95.

A sound recording for the blind was made in 1992: The Life and Times of a Good Keen Man: The First of a Trilogy. Read by Alan Beagle. Auckland: Royal New Zealand Foundation for the Blind, 1992. 1 sound cassette (4 hrs, 45 min.).

\section{B25. Gold and Greenstone 1993}

[all set left:] BARRY CRUMP | GOLD AND GREENSTONE | Illustrated by Dennis Turner [above all set left] | [centred: publisher's device: BARRY CRUMP

Kōtare 4, no. 2 (2001), pp. 3-160. 


\section{ASSOCIATES]}

On verso-title: "Published by Barry Crump Associates | 40 Airedale Street, Auckland, New Zealand | Copyright Barry Crump | First edition 1993 | Distributed by Becket [sic] Sterling Ltd | 28 Poland Road, Glenfield, Auckland, New Zealand ...". 192pp., dark green wrappers; 210mm. Printed by Mcpherson's Printing Group. 0908968000. \$19.95.

Novel. Hogg Loose Strides pp.186,189.

\section{Later printing:}

New edition 1996: Auckland: Hodder Moa Beckett Publishers Limited, 1996. 192pp., green wrappers, 209mm. Typeset by TTS Jazz, Auckland; printed by Griffin Paperbacks, Australia; text reset. 1869584600. \$24.95. At head of cover: "A New Zealand Classic".

A sound recording for the blind was made in 1993: Gold and Greenstone.

Read by Phil Harris. Auckland: Royal New Zealand Foundation for the Blind, 1993. 1 sound cassette (4 hrs).

Chapter titles: 'A funny old world', 'Sally', 'Quin', 'Flaxy Creek', 'Broken Creek', 'Daydream Station', 'Dancing Creek', 'Quin's Rock', 'Two-Thumb River', 'Horseshoe Creek', 'Wednesday Creek', 'Compass Creek'.

B26. Arty and the Fox 1994

[all set left:] BARRY CRUMP | ARTY AND THE FOX | Illustrated by Pat Trembeth | [centred: publisher's device] | Moa | Beckett

The sequence of preliminary pages is: p.[1]: title-page; p.[2]: 'Books by Barry Crump'; p.[3]: biographical information; p.[4]: publication details; p.[5]: 'Contents'; p.[6]: blank; p.[7]: illustration; p.[8]: blank; pp.9ff. text. "...Published in 1994 by Moa Beckett Publishers Limited | 28 Poland Road, Glenfield, Auckland, New Zealand ...": p.[4]. 192pp., grey wrappers, 210mm. Printed by McPherson's Printing Group, Australia. 186958080X. \$19.95.

Novel ("a good-hearted, throwaway, elongated yarn": Hogg Loose Strides pp.188, 192, with extract).

Later printings:

Reprinted 1994 unseen (listed in next).

New edition 1997: Auckland: Hodder Moa Beckett, 1997. On verso-title: "First published in 1994 | Reprinted 1994 | This edition published in 1997". 192pp., 
wrappers, 210mm. Printed by McPherson's Printing Group, Australia; offset from earlier edition. 186958595X. \$24.95. At head of cover:."A New Zealand Classic". In this edition more conventionally the biographical information is p.[1] and the title p.[3].

Chapter titles: 'The chickens', 'The cabbages', 'The fox', 'With a hiss and a roar', 'Innkeepers', 'Grave undertakings', 'With a bar', 'Road works', 'Sprung', 'A favour from the fox', 'Eight thousand bottles and a dog', 'The jackpot', 'Gnomes?'.

\section{B27. Forty Yarns and a Song 1995}

FORTY YARNS | AND | A SONG | Barry Crump | [publisher's device] | Moa | Beckett

The sequence of preliminary pages is: p.[1]: title-page; p.[2]: books by Crump; p. [3]: biographical note; p.[4]: publication details; p.[5]: dedication; p.[6]: Author's note; p.[7]: half-title; pp.[8-9]: contents; pp.lOff text. "ㅇ Barry Crump 1994 | Published in 1995 by Moa Beckett Publishers Limited..." (p.[4]). 231pp., dark blue wrappers, 210mm. Printed by Australian Print Group, Maryborough, Victoria, Australia. 1869581261. \$19.95.

"A collection of bits and pieces" (Hogg Loose Strides p.193); "...I ended up with a lot of material I couldn't fit in [The Life and Times of a Good Keen Man], things that have happened, things that have partly happened, and things that might have happened..." - Author's Note p.[6]. 'Sixpence an hour' is Crump's account of the publication of A Good Keen Man; 'The lizard skinner', 'The wayfarer', 'Garth', and 'Rum Jungle Jim' are accounts of his time in Australia.

Later printings:

New edition 1996: Auckland: Hodder Moa Beckett, 1996. Unseen (listed in next).

Reprint 1997. On verso-title: "First published in 1995 by Moa Beckett Publishers Ltd. | This edition published in 1996 | Reprinted 1997". 231pp., wrappers, 210mm. (Printed by McPherson's Printing Group, Australia).

1859584619. \$24.95. At head of cover: "A New Zealand Classic".

Chapter titles (prose unless otherwise stated): 'Formative years' [first published as 'Back when I was a boy' Southern Skies 1994: A29], 'Bucket and spade', 'Escapade', 'The Kiwi bomb' [first published as 'Turn left at Memory Lane' Southern Skies 1993: A17], 'The Kiwi postbox' [first published as 'Post taste' Southern Skies 1993: A16], 'Old Bullet', 'Hank', 'Unfortunate experiences' [first published as 'A bit of bad luck' Southern Skies 1994: A31], 'Woolworth', 'Bushman's holiday', 'Sense of humour', 'Three dog night' [first published in Southern Skies 1994: A22], 'Guts', 'Dan', 'Wild pork', 'Strawberry jam' [first

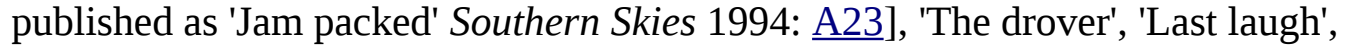

Kōtare 4, no. 2 (2001), pp. 3-160. 
'Sixpence an hour', 'The fabulous fritter', 'A dead cert' [first published as 'On a dead cert' Southern Skies 1994: A26], 'The lizard-skinner', 'The wayfarer' [first published as 'Strife on the ocean waves' Southern Skies 1994: A19], 'Garth' [first published as 'Snakes alive!' Southern Skies 1994: A30], 'Rum Jungle Jim', 'Safari in Ghuznee Street' [first published in Southern Skies 1994: A24], 'Spondylating Leptospirosis', 'Hammerhead', 'A piece of hell', 'The Eastern touch' [first published as 'Taken for a ride' Southern Skies 1994: A32], 'The last brumby', 'Kuri', 'The Brahman bull' [first published as 'One in the Bull's Eye' Southern Skies 1994: A20], 'Gold fever', 'A day with Unc', 'Clive's goats' [first published as 'Basil, nannies and the kids' Southern Skies 1994: A28], 'Letter to the I.R.D.' [poem, here with prose introduction as in earlier publication in Southern Skies 1994 (A21); reprinted without introduction in Barry Crump's Bedtime Yarns and Song of a Drifter and Other Ballads; here "damn" omitted before "good at minipool"], 'Anachronology' [slightly abridged from 'The man time forgot...' Southern Skies Dec. 1993-Jan. 1994 (슬) ], 'Bodies', 'No reference intended', 'Song of a drifter' [poem, first published in The Life and Times of a Good Keen Man; reprinted in Song of a Drifter and Other Ballads; separate printing with music by David Hamilton, 1999].

A sound recording for the blind was produced in 1995: Forty Yarns and a Song. Read by Bill Leathwick. Royal New Zealand Foundation for the Blind, 1995 (2 cassettes, 6 hrs, 15 min.).

\section{B28. Crumpy's Campfire Companion 1996}

\section{CRUMPY'S | CAMPFIRE | COMPANION | THE THIRD OF A TRILOGY | BARRY CRUMP | [publisher's device] | Hodder Moa Beckett}

"Published in 1996 by Hodder Moa Beckett Limited..." (verso-title). 168pp., wrappers, 210mm. Printed by McPherson's Print, Australia. 1869582888. \$24.95 Autobiographical. ".. .Third part of a trilogy on The Life and Times of a Good Keen Man ... collection of yarns ..." (back cover); "Author's note" p.5 identical to that in Forty Yarns and a Song.

\section{Later printing:}

Reprint 1996: "Reprinted in 1996" added on verso-title; otherwise as preceding.

Contents: 1. 'The Duggan brothers'; 2. 'The black boar'; 3. 'The real thing' [revised from 'Down on the farm' in Southern Skies 1995: A34]; 4. 'The post'; 5. 'Hard yakker' [revised from Southern Skies 1995: A37]; 6. 'Shiraz'; 7. 'Never seen anything like it'; 8. 'A new shotgun'; 9. 'The mighty Motu'; 10. 'Close shaves'; 11. 'Too much of a good thing'; 12. 'Streak's pub'; 13. 'Curie-pie' [first published as 'Thanx for the memory' in Southern Skies 1996: A40]; 14. 'Harry'; 15. 'By the seat of our pants' [first published as 'Stag party' in Southern Skies 1995: A35]; 16. 'Not cut out for it'; 17. 'Not cricket'; 18. 'Boots'; 19. 'State Highway Six'; 20. 'A lot of bull'; 21. 'Bush happy'; 22. 'Ad lib'; 23. 'A long haul' [first published in Southern Skies 1995: A36]; 24. 'Black man's logic'; 25. 'On the cutting room 
floor' [first published as 'Fear of heights' in Southern Skies 1995: A33]; 26.

'Beyond repair'; 27. 'Four-wheel drive'; 28. 'The wrong joke'; 29. 'The dog bloke'; 30. 'A soft touch'; 31. 'No trouble' [first published as 'No trouble...' in Southern Skies 1996: A39]; 32. 'On fire', with poem 'Fire' at end (here first printed; reprinted in Song of a Drifter and in Tribute). 23 and 24 are set in Australia; 31 set in India.

Extracts reprinted:

'Four wheel drive' is online as 'Beaut utes. Four wheel drive' at 'Aotearoa,

A Celebration of Kiwi Culture' at "The Peoples Embassy":

$<$ http://hammer.prohosting.com/ penz/aotearoa/ute.htm> and 'The black boar' at $<$ http://hammer.prohosting.com/ penz/aotearoa/boar.htm> (viewed 24.9.01).

B29. As the Saying Goes 1996

AS THE SAYING GOES | The Philosophy of a Kiwi Bushman | Barry Crump | [publisher's device] | Hodder Moa Beckett

"Published in 1996 by Hodder Moa Beckett..." (verso-title). [60]pp., dark_blue boards, 106x106 mm; blue dust-jacket. Typeset by TTS Jazz, Auckland; printed through Bookbuilders, Hong Kong. 186958354X. \$14.95. The book appeared soon after Crump's death in July 1996 ('New book published this week': TV3 News 4 July 1996).

Aphorisms and apothegms. "Every now and again we come across a description or a truth that tickles our fancy, as these have tickled mine. I've picked them up or I've thought them up over the years ..." (p.[3]).

\section{Later printings:}

2nd impression 1996 unseen (listed in next).

3rd impression 1996 ("Reprinted 1996 (twice)": verso-title).

Extracts reprinted:

Six of the sayings are quoted ('The Philosophy of the New Zealand Bushman') on the personal homepage of Imre F. Barna, a Hungarian physicist at the Institut fur Theoretische Physik of the Justus-Liebig-Universitat in Giessen, Germany $<$ http://service.physik.uni-giessen.de/ barna /english.htm> (viewed 8.10.01).

B30. Song of a Drifter and Other Ballads 1996

SONG OF A | DRIFTER | AND OTHER BALLADS | Barry Crump | Illustrated

Kōtare 4, no. 2 (2001), pp. 3-160. 
by | Pat Trembeth | [publisher's device] | HAZARD PRESS | publishers

On verso-title: "First published 1996 ... Published by Hazard Press Limited, | P.O. Box 2151, Christchurch, New Zealand | Cover [i.e. dust-jacket] painting by Dennis Kent | Illustrations by Pat Trembeth | Design by Quentin Wilson | Printed in New Zealand". 54pp., brown boards, 168x135mm; dust-jacket. 1877161063. $\$ 19.95$.

Poems. Introduction by Kevin Ireland pp.7-9 ("Crump's words belong to an agelong tradition of ballads and songs, and his use of these forms is authentic ... Crump was the greatest literary entertainer of his generation ... The only regret I have is that he started to write in this style so late ...").

Contents: 'Mustering Bullock Creek', 'Toyota' [reprinted in Tribute], 'Ode to a politician' [reprinted in Tribute], 'Journey' [revised from Barry Crump's Bedtime Yarns; reprinted in Tribute], 'Time of day' [first published in Bush _ Telegraph (C6); reprinted in Barry Crump's Bedtime Yarns and in Tribute], 'Cave' [first published in Barry Crump's Bedtime Yarns; here "rips" for "grips" stanza twelve], 'Battle' [first published in Barry Crump's Bedtime Yarns; here "maori" capitalised; also reprinted in Life and Times with first two stanzas reversed], 'Letter to the I.R.D.' ["IRD" in Contents; first published in Barry Crump's Bedtime Yarns; reprinted in Southern Skies 1994 (르), also in Forty Yarns and a Song (with prose introduction); comma omitted here after 'sir' stanza six; "my friend" here stanza twenty, elsewhere "old friend"], 'Bad Blue' [released on record as a 'A Dog Called Blue', 1970 (El); reprinted in Tribute], 'Cup of Tea' [reprinted in Tribute], 'Fire' [first published in Crumpy's Campfire Companion; reprinted in Tribute], 'Harry's piece of pain' [first published in Barry Crump's Bedtime Yarns; here dash for semi-colon penultimate stanza; reprinted in Tribute], 'Song of a Drifter' [first published in Life and Times; reprinted in Forty Yarns and a Song; separate printing with music by David Hamilton, 1999].

A sound recording for the blind was produced in 1998: Song of a Drifter and Other Ballads. Read by Merv Smith. Royal New Zealand Foundation for the Blind, 1998 (35 min.).

'Song of a Drifter' was set to music and published by David Hamilton in two settings: (a) Song of a Drifter. TTBB, Piano. 1999. 9pp., white wrappers, 258mm. Note on Crump and the work inside front cover: "The development of choral music in New Zealand schools has meant an increasing demand for music for male voices. This setting is part of a conscious effort to meet some of that demand. The setting is in a popular folk-ballad style for four-part male voices..."; (b) Song of a Drifter. SATB, Piano. 1999.12pp., white wrappers. "This version for the NZ Secondary Students Choir ... for mixed-voice choir and piano". Note on Crump and the work p.[12].

A further work by Hamilton, Crumpy!. TTBB, Piano. 2000. 25pp., white wrappers, 257mm, sets to music three poems by Crump, 'Mustering Bullock Creek', 'Toyota' and 'Bad Blue'. Note on Crump and his work inside front cover:

Kōtare 4, no. 2 (2001), pp. 3-160. 
"... 'Crumpy!' was written for the recently formed National Male Choir of New Zealand ... The texts are used by kind permission of Crump's widow Maggie Crump ... 'Song of a Drifter' may be added to the end of this cycle to create a group of four songs under the title 'Crumpy!' ... The pieces of this cycle can be made available separately.".

B31. Back down the Track 1998

\section{BACK DOWN | THE TRACK | PHOTOGRAPHS BY | BARRY CRUMP | TEXT BY | COLIN HOGG | [publisher's device] | Hodder Moa Beckett}

"... (C) 1998 Text and Photographs — Margaret Crump ... Published in 1998 by Hodder Moa Beckett Publishers Limited | (a member of the Hodder Headline Group) | 4 Whetu Place, Mairangi Bay, Auckland, New Zealand ..." (p. [112]). 111, 113pp., gatefold wrappers, 230x251mm. "Designed, typeset and produced by Hodder Moa Beckett Publishers Ltd. | Colour separations by Microdot, NZ. | Printed by Kyodo Printing Co. Ltd, Singapore". 1869586727. \$39.95

"... Crump's unique view of New Zealand ... accompanied by quotes from some of Crump's best-loved titles" — front flap.

\section{B32. The Pungapeople of Ninety Mile Beach 1999}

The | Pungapeople | of | Ninety | Mile | Beach | [set left:] Written by Barry Crump [centred:] Hodder Moa Beckett [below publisher's device] | [set right:] Illustrated by Natalie Ward

"Auckland: Hodder Moa Becket, 1999" (publication details on recto of lower free endpaper). 32pp (plus text on inside of both endpapers). 294x210mm, pictorial boards, pictorial dust-jacket. Printed by South China Printing Co.; film: Microdot, Auckland. 1869587782. \$24.95.

Humorous picture story book in rhyme for children.

\section{Contributions to Books}

This section includes writing by Crump first published in books by others. It excludes his contributions to periodicals, which are in section A, and interviews, even those quoting him verbatim, which are in Section $\mathrm{H}$. Extracts reprinted from his books are listed under the book they are derived from. Extracts from his final unpublished book are included in Tribute and in Hogg Loose Strides.

C1. Kevin Ireland. Face to Face, Twenty-four Poems. With an Introduction by Barry Crump. [Christchurch]: Pegasus Press [1963]. 39pp.

Kōtare 4, no. 2 (2001), pp. 3-160. 
Introduction by Crump pp.9-10: "... Now what the hell do I know about poetry except that I know Kevin pretty well and some of his poems look and sound okay ... He's a good bloke ... got three New Zealand writers guided off in the right direction...". On back of dust-jacket: "[Ireland] was the foundation editor of the Auckland literary magazine Mate which first published Barry Crump...".

Ireland reciprocated with an introduction to Crump's posthumous Song of a Drifter and Other Ballads in 1996 (B30): "In 1963 Crump wrote an introduction to my first book of poems, and saw to it that they got published..." (pp.8-9).

C2. Ron Helmer. Stag Party. Christchurch: Whitcombe \& Tombs Ltd, 1964.180pp (plus 8 pp of plates).

"Foreword" by Crump pp.[5]-6. Partly fictionalised account by a Canadian of deer shooting with Crump in the Urewera country. Crump features largely in the text (with reconstructed conversations) and in several photographs.

Reprinted: "Second impression November 1964"; new edition: Calgary: Monro Publishing, 1990. 0969383711 (green wrappers with same design as 1964 dustjacket; 1989 photo of Crump and Helmer on back cover).

C3. Jim Henderson, ed. Open Country, People and Places out of Town. Wellington: A.H. \& A.W. Reed, 1965. xvii,268pp. Published Oct. 1965, reprinted Nov. 1965, 1966, 1967, 1970, 1973, 1976, the last with ISBN 0589002791.

'The Good Keen Crump' pp.81-102, comprising: 'Rabbiting. Lindsay Broberg interviews Barry Crump, at 25 New Zealand's best-selling author, ever': pp.83-7 (a sound recording of this interview is held by the Radio NZ Sound Archive); 'City lights': pp.88-90 (ill. by Ray Labone); 'Pigdogs. Barry Crump interviews Bruce Murphy': pp.91-7 (ill. by Roger Hart); 'Crumpy cracks the crocs': pp.98102.

'Pigdogs. Barry Crump interviews Bruce Murphy' reprinted in Jack Pollard, ed. Wild Dogs, Working Dogs, Pedigrees \& Pets. Dog and Man in Austral__tan and New Zealand Life. Melbourne: Lansdowne, 1968. xiii,297pp. Pp.260-5. (Also published with imprint: Wellington: A.H. \& A.W. Reed, 1968.)

C4. Bob Lowe. Prayers for New Zealanders. [Christchurch]: Whitcombe and Tombs [1973]. 52pp. 0723303606. Foreword by Crump p.[7] ("I've never met God personally, but I have met Bob Lowe..."); Lowe's introduction p.[9] tells of "a simple, unlettered fellow named Crump" seeing home a drunk academic who "had earlier been very rude about Crump and his contribution to New Zealand literature"; hopes "slipping Crumpy's name in" will help sell the book.

C5. A Lawful Excuse. Shooting Script. (Winners and Losers. Films Adapted from New Zealand Short Stories). Wellington: Department of Education, 1977. Ills.

Kōtare 4, no. 2 (2001), pp. 3-160. 
Script of the film (Dl) based on Crump's story 'Lawful excuse' (ㅅ10, B9, B22). Includes pp.i-ii: 'General Introduction' (unsigned); pp.iii-iv: 'Notes from the Film Directors' by Ian Mune and Roger Donaldson ("... the Crump stories are yarns in translating them into films, the dialogue has to be created...") and pp.iv-v: 'Author's Comment on Film' by Crump: "... they have been able to capture the spirit - the atmosphere - of the story ... in one point I can see that Aardvark has been indiscreet. I would never have had the success of the mushroom venture follow on them getting the young bloke (Johnny) into trouble ...".

C6. Barry Crump, ed. Bush Telegraph. Published by Firstlight Productions [Auckland]. Cover drawings by Peggy Spicer. Typed by Sue. Robyn handled the mail. Edited by Barry. Printed by Business Printing Works, 22-24 Nelson Street, Auckland. 1982. 56pp. [On cover: Bush Telegraph, A Collection of Original Verse. Edited by Barry Crump].

A selection of poems sent in by listeners to Crump's Radio Pacific 'Bush Telegraph' programme. "This book is dedicated to the hundred and fifty odd contributors from whose work these poems and illustrations were selected." Edited by Crump and one poem p.28, 'Time of day', by "Barry" [reprinted in Barry Crump's Bedtime Yarns, Song of a Drifter, and Tribute]. Crump says in Life and Times: "...we got two thousand of them printed ... _ we only offered it to our listeners, by mail ... It paid for itself in the first two weeks, and sold out altogether in four weeks ... Robyn and I had risked five thousand dollars ... the book made fourteen thousand ..." (p.208).

C7. John Dunmore, ed. The Book of Friends. Compiled and edited by John Dunmore. Waikanae: The Heritage Press, 1989 on behalf of the Child Cancer Foundation, Auckland. 0908708122. 92pp.

Short pithy quotes (with autographs) sent in by well-known New Zealanders; Crump p.34 contributes a short poem learnt from his mother. (The poem appears in the Sunday News 27 May 1973: 27, 38 and was read by Sam Hunt on a Gallery television panel discussion on the arts; Crump had been invited to appear and recited the poem to the producer over the phone.)

C8. Sigrid Crump. Bushwoman, A Search for the Perfect Place. Auckland: Reed, 1995. 079000402X. Ills, maps. 154pp.

Sigrid Kohler arrived in New Zealand in the 1960s and here recounts her twenty years roaming the back country as "the lone German bush rat" before marrying Crump's brother Bill. Introduction by Crump p.7, who features in the book pp.2530, 34-6, 82,101-4; photo p.102.

Reviews: "'Bush rat" tells her tale of roaming' Evening Post 7 luly 1995: 20; Anna Dunbar, 'Tale of a good, keen search', Dominion 14 Oct. 1995 (Sigrid Crump guest speaker at 'Listener' Women's Book Festival: difficulties of finding a

Kōtare 4, no. 2 (2001), pp. 3-160. 
guest speaker at 'Listener' Women's Book Festival: difficulties of finding a publisher and translating some words into German).

C9. Tim Rogerson, ed. Tall Tales and True from Well-known Neiv Zealanders. Cartoons by Eric Heath. Wellington: Life Education Trust, 1996. No ISBN. 68pp.

The editor states: "...Hello, I'm Colonel Tim Rogerson, a trustee of Life Education Trust. I put this uniquely New Zealand book together in order to raise funds for educating 5-12 year old children ... This book contains interesting and amusing stories written by prominent New Zealanders_..." $<$ http://www.l21agent.com/lifeedtrust/true tales.htm> (viewed 12.5.01).

The man from the bottom of the barrel' by Barry Crump (signing himself at end: 'Itinerant compiler of fantasies') pp.7-9 (with ill. by Eric Heath) [first published as 'Bottom of the barrel' Southern Skies 1995-6: $\underline{\text { A38]. }}$ ].

C10. Molly Anderson. Household Gods: New Zealand Cats at Home. Photography by Annelies van der Poel. Christchurch: Hazard Press, 1996. 0908790880. 111pp.

"Well-known New Zealanders talk about their cats". Crump pp.[12]-15 with three photos of his cats and one of him.

Review: Stacy Gregg, 'The cat's out of the bag', Sunday Star Times 27 Oct. 1996: 13 (" ... You couldn't get a wilder life for a feline than being the companion of Barry Crump. Crump had been a last minute inclusion, and a timely one. 'He died the morning I sent his story away to the printers.' The photographs of Crumpy's two cats are the most poignant, particularly the one of little Ruru ... The photos were taken after Crump's death and depict a lonely cat without a master. But then, no one owns a cat...").

C11. Jim Weir, ed. New Zealand Wit and Wisdom, Quotations with Attitude. Auckland: Tandem Press, 1998. 1877178373. [vi],330pp.

Eight quotations from Crump pp.65-6 (A Good Keen Man, Hang on a Minute Mate, Life and Times of a Good Keen Man). Originally compiled jointly with Harry Orsman, but they went separate ways after disagreeing on what to include; Orsman's 1988 Heinemann Dictionary of New Zealand Quotations includes no Crump.

\section{Stage and Screen Adaptations of Works by Crump}

\section{D1. A LAWFUL EXCUSE.}

Film 16mm, colour, 30 min., made by Aardvark Films, Auckland, 1976 (part of series 'Winners and losers'). Directed by Roger Donaldson; produced by Roger 
Donaldson, based on Crump's short story 'Lawful excuse' (ㅅ10, $\underline{\text { B9 }}, \underline{B 22})$. The cast included Ian Mune, Ivan Beavis and John Black.

Released on videocassette, and later included in a compilation: New Zealand Short Stories. Wellington: The Gibson Group, 1986. 103 min. With Teachers' notes. ('A lawful excuse' by Barry Crump; 'Big brother, little sister' by Witi Ihimaera; 'Old man's story' by Frank Sargeson; 'Woman at the store' by Katherine Mansfield.) \{Unseen: held by University of Otago.) The shooting script of the film with notes by the film makers and by Crump was published in 1977 ( $\underline{\mathrm{C}}$ ) and the relationship between the film and Crump's story is discussed in Bill Lennox, Film and Fiction, Studies of New Zealand Fiction and Film Adaptations. Auckland: Longman Paul, 1985. 0582857104. xv,152p. Pp.1-16 (with 3 stills from the film); $\underline{\text { H118. }}$.

\section{D2. HANG ON A MINUTE MATE!}

Film, 16mm, colour, 71 min., made by Hang on a Minute Mate Film Partnership (with the assistance of Broadcasting Corporation of New Zealand), (C) 1982.

Director and producer Alan Lindsay; screenplay by Alan Lindsay, based on stories in Hang on a Minute Mate and two ('Time flies' and 'Hokonui Hank') in There and Back; script editors Barry Crump, Grahame McClean, Coral Davidson. The cast included Alan Jervis as Sam Cash and Kelly Johnson as Jack Lilburn. Shown on TV Two 22 Nov. 1982 8pm and sold on video previously.

Further details and critical appraisal of the film in Helen Martin and Sam Edwards. New Zealand Film 1912-1996. Auckland: Oxford University Press, 1997 (0195583361) p.85: "aimless road movie about an aimless Kiwi joker ... Cash is one of a gallery of Crump characters perpetuating the Kiwi joker mythology set in motion by John Mulgan's Man Alone ... clumsy in shooting style ... barely cinematographic ... amateurish acting, a wordy script..."; Hogg Loose Strides pp.146,153,155.

Crump commented on his part in the film script in a 1980 interview ("...preparing to travel to Christchurch to oversee the making of a television comedy series based on his Hang on a Minute Mate stories. 'I'd like to see that they make a good job of the films' ...", NZ Woman's Weekly 8 Dec. 1980: 64-5, 67; H87) and in 1981 (Phil

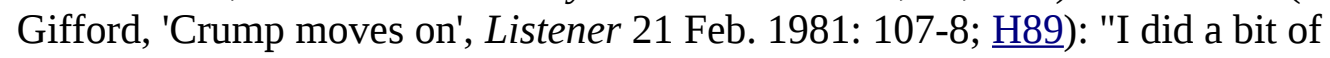
rewriting on the scripts. Added a bit to them here and there, just the dialogue. Really dialogue's very difficult..."; and a further interview marked the television screening of the film, Tony Reid, 'Crump flags it away', Listener 20 Nov. 1982: 22-3, 25. A press release provided preview information for newspapers, for example 'Sam Cash hangs on to TV Two', Evening Post 22 Nov. 1982. See $\underline{\text { H78, }}$ H86, H100-H102.

Crump's story 'Trap' from Warm Beer and Other Stories was sold for a television play according to the dust-jacket flap of Bedtime Yarns, but this appears to have fallen through, as did planned films of Gulf and Wild Pork and Watercress (see notes to $\underline{\mathrm{B} 6}, \underline{\mathrm{B} 19})$.

Kōtare 4, no. 2 (2001), pp. 3-160. 
notes to $\underline{\mathrm{B} 6}, \underline{\mathrm{B} 19})$.

Crump said in 1981 that he wrote "a couple of television plays but, when he was offered 'pathetic money' for them he put them on the shelf" (NZ Herald 15 Sept. 1981: 16).

\section{D3. HANG ON A MINUTE, MATE}

Stage play by Anthony McCarten. Opened Downstage, Wellington, Feb. 141992 with cast including Martyn Sanderson as Sam Cash, Tim Balme as young Jack, Peter Vere-Jones as narrator (Jack in later life) and Donna Akersten, William Kircher, Michael Haigh, John Wraight, Tina Regtien and Carmel McGlone. Directed by Ross Jolly. Staging (involving two revolving stages) by Tony Rabbit.

Printed copies produced on demand by Playmarket, Wellington, 76pp $\underline{\mathrm{A}} 4$, unbound.

An article on the play, Mike Houlahan, 'Crump's keen man on stage', Evening Post 8 Feb. 1992, quotes Crump: "They got in touch with me in the middle of last year ... I didn't see how they were going to do it... I must say I'm pleased with it and very impressed ... it's still a part of the tapestry of New Zealand life. I still live a bit like that...".

Reviews:

Laurie Atkinson, 'Crump's virtues kept, but momentum lost', Evening Post 17 Feb. 1992 ("..these tall tales and amusing yarns remain stubbornly solo turns, best performed in a pub or round a campfire...");

Patricia Cooke, 'Hark back to simpler days', Dominion Sunday Times 1 March 1992 ("...has used Barry Crump's Sam Cash books set in the fifties as the basis of a picaresque comedy ... narrator holds up action ... most likeable character ... an old Ford Truck ... apparently made out of number eight wire.").

\section{E. Music Recordings by Crump.}

E1. A Dog Called Blue. 7 inch, 45 rpm record, Kiwi SA.70,1970. 3.59 min. Performed by Barry Crump and Paul Harrop's Good Keen Men. Written by Crump, arranged by Harrop. (On flipside: 'Ballad of a Travelling Gentleman', composed by Crump.) (Turnbull Library copy in plain white sleeve, possibly original; copies also at Hocken Library and Radio NZ Sound Archive.)

250 copies were sold of this "laconic folksy grumble": Hogg Loose Strides pp.117, 162, calling the record Bad Blue, as does Crump in Life and Times (p.128), the title of the poem (printed in Song of a Drifter and other Ballads). A Reed memo (1970?; ATL MS-Papers 6548) mentions a planned recording, "'Bow Wow Ballad' — the song will be his own — a comic(?)" and a later memo (13.7.70) quotes a 
reporter at the launching termed the record "half singing, half talking" (Jacquie Billson Thursday 29 Oct. 1970: 18-19; $\underline{\mathrm{H} 54})$.

The recording was included in a Radio NZ broadcast 'Profiling New Zealand Music' on 17 Oct. 1970 introduced by Alan Beck (copy in Radio NZ Sound Archive) and on a compilation of New Zealand folksongs, A Homestead in New Zealand, Wellington: Kiwi Pacific, 1986 (KTC-KML6; cassette, with accompanying booklet).

E2. Sailing Away. 7 inch, 45 rpm record, stereo, 3.59 min. [Auckland]: BNZ Challenge Cup, 1986. BNZC 12. Distributed by CBS Records New Zealand. Produced and arranged by Murray Grindley. Crump had a one line solo ("One people on the land") in 'Sailing Away' on this recording produced to support the Bank of New Zealand challenge for the America's Cup in Perth in 1987. Also screened on television (Fll).

The song was included in a compilation (two compact discs), New Zealand, Our Land, Our Music. Volume two. [Auckland]: EMI, 1997, which also includes E3.

E3. Side by Side, Crumpy \& Scotty. [Auckland]: Columbia, 1991. 1 sound cassette.

A song performed by Crump and Lloyd Scott on one of their Toyota advertisements ( $\underline{F 16})$ released to support the 1992 New Zealand challenge for the America's Cup ("Crumpy \& Scotty together again in the hit New Zealand musical for the America's Cup" - wrapper); this song, repeated on side two, reached number two in the charts (selling 5,000 copies; The Press 16 May 1992: 6).

The song was included in a compilation (two compact discs), Nezv Zealand, Our Land, Our Music. Volume two. [Auckland]: EMI, 1997, which also includes E2.

E4. Wordworx. Buzz Words, Rhythm 'n Verse with Attitude. Auckland: Pacific Mirror Image [1997]. Performed by Keith Newman, poet-lyricist "who wrote and voiced all tracks", and others. Compact disc ("Enhanced CD! Multimedia book with project profiles and lyrics"). The track 'Kiwi Attitude' includes a "guest appearance" by Crump saying "Gidday, how are ya? that's the story".

The 'Wordworx webzine' web site (<http://www.wordworx.co.nz/ index.html>) has a link to the same recording of Crump at

$<$ http://www.wordworx.co.nz/crump1.wav> (viewed 25.9.01).

\section{F. Film and Televisions Appearances}

(for television and radio interviews and documentaries on Crump see Section $\mathrm{H}$ )

Kōtare 4, no. 2 (2001), pp. 3-160. 
"He was proud of his acting abilities and gave 'writer and actor' as his occupation in his Who's Who in New Zealand entry - though he several times expressed his dislike of film work." Max Lambert's obituary (ㄴ212).

\section{F1. Runaway.}

Made by Pacific Films Ltd, (C) 1964. 35mm, black and white, 102 min. (later released in England as 'Runaway Killers', cut to 80 min.; released on video by Learning Media, Wellington, (C1994,047805840X, 1 videocassette (90 min.) with 15pp booklet of teacher's notes). Directed and produced by John O'Shea who wrote the screenplay with John Graham based on an idea by Hubert Witherford. "A high-living, high-flying accountant ... gets heavily into debt and ... goes on the road..."; among the characters he encounters is Clarrie, played by Crump, "the prototypical Kiwi joker": Helen Martin and Sam Edwards, New Zealand Film 1912-1996. Auckland: Oxford University Press, 1997 (0195583361) p.54 (with still showing Crump), which has further details and a critical appraisal.

Celluloid Dreams, A Century of Film in New Zealand. Wellington: IPL Books, 1999 (0908876963) hails "a superb Gothic encounter with the sinister Clarrie (Barry Crump) ..." (p.103); see also Jonathan Dennis and Jan Bieringa, Film in Aotearoa Nezv Zealand. Wellington: Victoria University Press, 2nd ed., 1996 (0864733097) pp.31-2 (with another still showing Crump). Catherine de la Roche's radio review of the film, reprinted in Performance, Palmerston North: Dunmore Press, 1988 (0864490827) pp. 128-31, concludes: "By far the best episode is one in a mountain hut with Barry Crump as a hunter gone bush. The dialogue is witty and everyone performs wonderfully".

John O'Shea talks of Crump and the film in his Don't Let it Get You (1ㅡㄹ $)$ pp.34-6, with two stills of Crump. Crump comments \{Life and Times p.121): "... I played the part of a crazy hermit. It was my first experience of film work and I've never liked it much"; Hogg Loose Strides p.88.

\section{F2. Pictures.}

Made by Pacific Films Ltd, (C) 1981. 35mm, colour, 87 min.: a brief newspaper article (Dominion 5 July 1980; $\underline{\text { H82) }}$ ) says Crump was to have a part in the film but this has not been confirmed.

F3. Working with GST.

In 1985 Crump and Peter Bland appeared in a 15 min. video produced by George Andrew to introduce businesses to the planned Goods and Services Tax. Bland is the befuddled proprietor of a small business, Potter's Possum Paradise, and has the tax explained to him by an old supplier of possum skins, played by Crump, whose nephew, Young Herb, works for the Inland Revenue "down Dannevirke way". The video was accompanied by a short booklet laying out the saga of Potter's Possum Paradise and answering other questions about GST. (Copy of

Kōtare 4, no. 2 (2001), pp. 3-160. 
video held at NZ Film Archive.)

The film attracted criticism as being party-political, as reported in the 6.30 TV1 television news 5 Nov. 1985; the Radio NZ sound archive holds a recording (5 Nov. 1985) of Paul Davenport reporting on the controversy over Crump's participation; see also The Press 7 Nov. 1985: 2 and H116. The video was included in 'GST' in Money Go Round, shown 1 Oct. 1986.

F4. Marine Reserves - Why We Need them.

Television New Zealand in association with Department of Conservation, 1989. 1 videocassette, colour, 13 min.

Fronted by Crump, the video explains the nature and importance of marine reserves. (Copy held at Wellington CityLibrary.)

F5. TELEVISION

From 1966 Crump became well-known as a television presenter, doing skits and interviews on the local Auckland programme Town and Around ("a Wednesday spot is always marked for one of Crump's out of town expeditions": Auckland Star 8 July 1966); Life and _ Times pp.127-8; Hogg Loose Strides pp.97-9, 101,104; Barbara Magner Tribute pp.156-8; George Johnston Tribute pp.120-2;

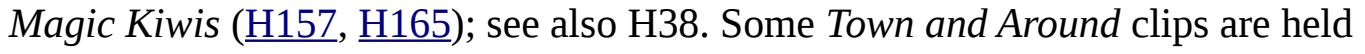
by the New Zealand Television Archive.

F6. In June-July 1966 he scripted and acted in a children's programme on AKTV2 called Yo-Heave-Ho (see $\underline{\text { H36)}}$ ); Life and Times p.128; Hogg Loose Strides p.101 quotes a review.

F7. Later he "did some TV work" with country singer Tex Morton (Life and Times p.130).

F8. Kevin McMenamin, The Press 12 July 1976: 15, notes Crump as "involved with" the television comedy 'Buck House' (1974), and that he appeared on television advertising ballpoint pens.

F9. He had a guest spot on the cooking show of Hudson and Halls (18 Sept. 1981).

F10. In March 1986 he appeared on Lifestyles of the Rich and Famous (H136; Hogg Loose Strides p.162).

F11. In May 1986 he appeared with other well-known New Zea-landers singing 'Sailing Away' in the television promotion for the America's Cup challenge (a copy of the 2 min. long ad, 'America's Cup Yacht Race KZ7. Sailing Away', produced by Fink \& Hart for Colenso Advertising, is held at the NZ Film 
Archive; it is also included in a 1994 compilation entitled 'Selling New Zealand. Great Big Melting Pot'; the song was released as a recording: E2).

F12. Hogg Loose Strides p.182 notes a video with Crump "and All Black Buck Shelford aimed at offering inspiration to young business people".

F13. In Chapter 25 of Campfire Companion Crump recounts making a promotional film for New Zealand tourism with American Leeza Gibbons.

F14. George Johnston in Tribute (pp.120-2) describes Crump acting in a Land Rover television commercial and in a promotional film at Matawai.

F15. In 1967 he appeared in a 20 second ad for Knightsbridge Carpets made by Advertising Associates (copy at NZ Film Archive: "Barry Crump plays a knight ignored by his princess, who shows more interest in his Knightsbridge carpet than in him"); plate in Hogg Loose Strides and humorous account in Campfire Companion pp.120-1.

F16. Between 1982 and 1995 he appeared with Lloyd Scott in a series of eleven 60 second ads for Toyota off-road vehicles made by Silver Screen Production Company for Colenso Advertising (Life and Times pp.203-4,207,217-8; Campfire Companion pp.137-41; Hogg Loose Strides pp.150-1, 160-1, 181; Tribute pp.16470). The NZ Film Archive holds copies of three, including the 1984 urban 'Wedding' which was "screened only twice before being taken off air on the grounds that it may encourage dangerous driving": Nick Perry, Dominion of Signs ( $\underline{\mathrm{H} 191})$ p.56; see also $\underline{\mathrm{H103}}, \underline{\mathrm{H} 107}, \underline{\mathrm{H} 108}$, Hill, $\underline{\mathrm{H} 150}, \mathrm{H} 198$. Perry has stills from this commercial (p.57) and from the Toyota America's Cup campaign commercial (p.61). Some of the ads were included in 'The Hard Sell' ("a look back at television commercials and a few of the actors who have become household names") in The Way We Were series shown TV1 10 Jan. 1996. Footage of Crump was used in other programmes in this series (first shown TV1 6 Dec. 1995), including 'Hunting Shooting Fishing' (shown TV116 Dec. 1997; also issued on a video compilation by Communicado).

The Toyota ads were also on radio (Radio NZ Sound Archive holds seven from 1985) and in newspapers: for example Dominion 30 Jan. 1986 has two full-page ads, "1985 Toyota success saves Crumpy's favourite hat" (with picture of dinner fork) and "Crumpy once said he'd eat his hat if Toyota wasn't 1985's Number One for Commercial vehicles......" (picture of hat and dinner knife); Dominion 15 Jan. 1990 has three full pages $(7,9,11)$ with full-page photo of Crump p.7.

\section{F17. RADIO}

Crump first worked on Radio Pacific in 1981 sharing the breakfast session with Paddy O'Donnell then from 17 August hosted an early-morning talkback show, The Crump Hour, later The Bush Telegraph (Life \&Times pp.204-16; Tribute p.132; see also C6, H91, H92; Hogg Loose Strides pp.150-1); when he left after 
fourteen months to "go bush" he was succeeded by Jim Henderson (Jim Henderson's New Zealand (1ㅡㄹ) p.130).

F18. Crump was interviewed a number of times on radio (listed in Section $\mathrm{H}$ by date); other miscellaneous items held in the Radio NZ Sound Archive include: 'On finding herd of 200 red deer Sth Westland' (1967 2 min. 40 sec); 'Talking of Shorty, panning for gold, Cook Islands, shipwreck in Australia' (recorded 27 Nov. 1980, 9 min.); 'Unusual radio item about dogs' (1970s, 1 min.); 'Radio Auckland 1ZB. Air check (60 min.) of first day of new format as News/Talk 1ZB, 16 March 1987. Host Paul Holmes. Includes Barry Crump on humour'; '1990 celebrations (150 years of New Zealand's nationhood). Sir Paul Reeves, Sir Edmund Hillary and Barry Crump talk to Sean Plunkett about their ideas for 1990'.

F19. A Reed memo of 8.7.70 (ATL MS-Papers-6548) mentions a radio play by Crump, 'Ergesso' (?) about "a metho and a passerby".

\section{G. Reviews of His Books}

Numbers for entries in this section correspond to the equivalent number of the book being reviewed from Section $B$.

\section{G1. A Good Keen Man}

J.H. [Jim Henderson]. NZ Listener 25 Nov.1960:16 (with port.) ("... a good alive book ... good terse descriptions ... handle kiwi yacker well..."); reprinted in Denis Welch, ed. The Listener Bedside Book No.3. Auckland: W \& H Publications, 1999.1877214086.304pp. P.99.

"Penguin". NZ Weekly News 14 Dec.1960:36.

W.F. 'One for that small corner in the Christmas stocking.' Bay of Plenty Beacon 14 Dec. 1960 ("remarkably like real life").

N.W. [Nevile Webber] 'A deer culler's life.' Marlborough Express 24 Dec. 1960 ("one of the outstanding non-fiction books of the year").

D.K.Y. [David Yerex] NZ Dairy Exporter 36, 7 (Jan. 1961): 49 ("...good reading [for deerstalkers]... I doubt [others] will appreciate more than a paragraph or two...").

Grant Graham. 'Well-culled account that should please.' The Southland Times 7 Jan. 1961 ("a most articulate voice").

C.R.I.M. 'Deer culler turns author.' Freedom Jan. 171961 ("undoubtedly one of the best New Zealand books of the year").

Kōtare 4, no. 2 (2001), pp. 3-160. 
John Hartford. NZ Home Journal Feb. 1961: 111 ("a gem").

J.W.G. [Jack William Goodwin] National Education 43 (July 3 1961): 281

("deadpan matter-of-factness ... believing that most New Zealand writing is too earnest and serious").

Roderick Finlayson. Landfall 59 (Sept 1961): 271-2 ("typically New Zealand ... understatement and an ability to laugh at one's own predicament").

D.A.M. [D.A. Mee] Canterbury Mountaineer 9, 30 (Oct. 1961): 71 ("a series of amusing incidents ... keen perception of people and surroundings in a rugged life ... Don't miss this book").

Dennis McEldowney. Comment 9 (Spring 1961): 38 -9 ("a line that goes back to Samuel Butler and to Lady Barker's shepherd's yarns ... artfully artless...").

J.G. Wilson. NZ Alpine Journal 19,48 (1961): 178 ("a New Zealander in full swing, talking unselfconsciously on paper, about country and people and happenings that are unique to New Zealand, in a way that previously New Zealanders have only been able to achieve verbally ... a grand addition to New Zealand back-country literature").

G2. Hang on a Minute Mate_Ross Annabell 'Backblocks scribe has another winner.' The Daily Post 18 Oct. 1961: 5 ("a master of rich Kiwi dialogue").

Anon. 'Back country life.' The Press 21 Oct. 1961 (" ... a light-hearted intimate glimpse of back country life...").

J.H. [Jim Henderson] NZ Listener 3 Nov. 1961: 35-6 ("a book to cherish, to read to your sons. Many Kiwis will reckon this is THE New Zealand novel: she's sneaked up on us ... out of the scrub...").

D.G.B. [(Donald) Gordon Buchanan] Otago Daily Times 15 Nov. 1961:16 ("One of the questions posed by ... A Good Keen Man was whether he could do it again ... Barry Crump has succeeded... Sam Cash ... in the tradition of 'The Shiner'... can probably trace his ancestry back to Baron Munchausen ... really a connected series of short stories ... every story is fit to be an-thologised ... The vivid colloquial style never lapses off key ...").

[John Hartford?] NZ Home Journal Dec. 1961:126 ("this gem of a book").

J.W.G. [Jack William Goodwin] National Education 43 (Dec. 1961): 523.

K. Jackson. Fernfire 8 (Jan. 1962): 19

D.K.Y. [D.K. Yerex] NZ Dairy Exporter 37,8 (Feb 1962): 42 (".. .anecdotes woven into a loosely knit saga ... good reading for anyone who finds pleasure in anything less than profundity ... writes from within his world ... he not only

Kōtare 4, no. 2 (2001), pp. 3-160. 
knows these people, he is one of them...").

P. Day. Landfall 62 (June 1962): 198 ("... Mr Crump's vein is not worked out but it is showing diminishing returns").

Denis Taylor. Comment 12 (July 1962): 35-9 ("... fluency of New Zealand idiom and material... [but] has not... fully realised his material... has hold of a myth equal to the way of life he described... [but] has constructed no organic action to bring it into full meaning. New Zealand must wait yet for its Voss...").

G4. One of Us.

Anon. Auckland Star 16 Nov. 1962

J.K. Baxter. NZ Listener 29 March 1963: 18 ("One cannot dismiss Crump as a raconteur ... I suspect that One of Us is the satire on New Zealand manners and morals which nobody else has written, except Sargeson in an occasional equally wry fable..."); the review is reprinted in Denis Welch, ed. The Listener Bedside Book No.3. Auckland: W \& H Publications, 1999 (1877214086). 304pp. Pp.98-9.

G5. There and Back

Grant Graham. The Southland Times 7 Sept. 1963 ("Crump shoots his best lines yet").

Anon. The Press 21 Sept. 1963 ("Some parts ... show a greater subtlety than the author has revealed in earlier books").

W.D.S. 'Crump cashes in again on Sam Cash.' Hawkes Bay Herald Tribune 28 Sept. 1963 ("scraping near the bottom of the barrel ... if such a word is possible, most unCrumpish").

J.K. Baxter. NZ Listener 11 Oct. 1963: 18 ("...the satire could be described as heavy sniping with a .303 rifle ... In some ways Sam Cash is any New Zealander's idea of himself ... Crump's prose has now reached the limit of terseness and laconic energy").

J.W.G. [Jack William Goodwin] National Education 45 (Dec.2 1963): 521-3

("Are we drab and sheeplike ... national appraisal... shrewd").

G6. Gulf

Bevan Burgess. 'Barry Crump changes gear.' Auckland Star 17 Oct. 1964 (Crump has not "written himself out" ... "like Mr Crump's earlier books, [it] has a solid backbone of good-humour and wit ... but ... also contains marked differences... does not belong to the oral tradition of the 'tall story'... none of the sometimes bitter misogyny ... not a collection of unrelated tales... ends unexpectedly"). 
bitter misogyny ... not a collection of unrelated tales... ends unexpectedly").

B. Mitcalfe. NZ Listener 22 Jan. 1965:12 ("Barry Crump, the dinkum Kiwi, has translated himself into dinkum Aussie, and the metamorphosis is complete and convincing ... I have heard Barry Crump criticised on the grounds that he has gleaned his stories from other's [sic] yarns. Only in a smallminded_country would such a comparison be possible. He shapes what is formless, transforms what is inarticulate, into folklore. That it derives from living people is a virtue possibly Barry Crump's greatest virtue.").

An unidentified reviewer accused Crump of staging his Australian shipwreck (는) to publicise the book: Life and Times p.119.

\section{G7. Scrapwaggon}

D. Hall. NZ Listener 15 Oct. 1965:19.

Anon. Fernfire 13 Dec. 1965:34 ("another tale in the well known Crump style").

Jim Kidson. 'Crump at the dump.' Evening Post 10 May 1986:24 (".. .Sadly, the characters ... are skeletons and need to be rounded out. The plot, too, requires more work. Barry Crump in a hurry.").

Anon. 'Vintage Crump.' The Christchurch Star 21 June 1986 ("The characters are wonderful and the dialogue true. What more could you want?").

Linda Sanders. 'The colour of a Crump story.' Dominion 23 Aug. 1986 ("... older New Zealanders will remember his books. He is a wonderful story teller. There is nothing clever about his work. It offers pure entertainment ... a master of understatement...").

G8. The Odd Spot of Bother

Jillian Allison-Aitken. 'Classic Crump.' The Southland Times 20 Sept. 1997: 22 reviews new editions of A Good Keen Girl, No Reference Intended ("a look at the absurdities of human nature") and The Odd Spot of Bother ("my favourite").

\section{G10. A Good Keen Girl}

D.H. 'Mr Crump is a little bewildered.' Auckland Star 19 Sept. 1970 ("...first twothirds ... is Crump as his laconic best... fades away to a half-hearted conclusion ... intriguing to recall how seldom women have figured in the previous eight books ... when a genuine female ... appears, our good keen author becomes a bit bewildered").

\section{G11. No Reference Intended}

Kōtare 4, no. 2 (2001), pp. 3-160. 
poorish short story spun out to the point of absurdity").

Steve Trotman. 'Evergreen Crump a joy.' Wairarapa Times-Age 2 Aug. 1997.

\section{G12. Bastards I Have Met}

Stephen Danby. 'Right year.' Nezv Zealand Sunday Times 5 Oct. 1986 ("A subversive element has suggested that almost all of New Zealand's literature has been 'homosexual'... [this book] is the epitome of such writing ...").

Brenda Pratt. Sunday Star 2 Nov. 1986 ("Some of the entries flag...").

Glyn Strange. 'Barry Crump's file.' The Press 15 Nov. 1986:26 ("fun to read").

J.N.M. 'Vintage Crump.' Christchurch Star 20 Sept. 1996 ("...as usual, Crump is rollicking good fun. He has been underestimated as an observer of the New Zealand scene and idiom. When you read him you make the acquaintance of the real New Zealand".).

\section{G15. Shorty}

Mervyn Cull. 'Back to his original keen form.' NZ Herald 8 Nov 1980: B 5 ("Crump as good as we have ever read him").

Tony Potter. 'Good keen golfers.' Auckland Star 15 Nov. 1980 ("a cracking good story-teller, with a fine ear for dialogue, and a sharp insight into human behaviour ... an amusing read with some interesting, all-too-real characters...").

Bruce Watson. 'Crump amuses.' Evening Post 20 Dec. 1980 ("a very funny book"). David Hill. Listener 21 March 1981:84-5.

\section{G17. Mrs Windyflax and the Pungapeople}

Ann Packer. 'Crump's yarn no classic' Evening Post 8 Sept. 1995:5 ("... while a rollicking read for the most part, fizzles quite badly towards the end... The vaguely- rhyming story is hard to follow, and the illustrations full of inconsistencies ... The local policeman's made to look stupid (Crump's revenge, no doubt) ... Classic? Not."). Lynne Jackett. Dominion 4 Nov. 1995 ("fantastic slapstick backblocks romp").

Frances Plumpton. Quote Unquote29 (Nov. 1995): 31 ("...a lot of fun but I won't include it in my list of New Zealand's children's classics").

Rob Finlay. New and Notable, Books for the Secondary School Library 12, 5 (Nov. 1995): 2 ("will appeal to people of all ages ... skilfully told in rhyme, subtly and skilfully humorous ... the combination of Crump's understatement and 
Ball's hyperbole makes a picture book that will become a classic").

Iain Sharp. 'Ball and Crump — a collector's item.' Sunday Star Times 13 June 1999 F 11 ("... the legendary author's only attempt at writing specifically for children ... Crump and Ball make a good team ... Ball's brilliance as a caricaturist gives personality to characters Crump has only sketched in lightly...").

G18. The Adventures of Sam Cash

Kevin J. Whitelaw. 'Good keen man, 25 years on.' The Press 21 Dec. 1985: 22 (".. still provide a good laugh. But the changing years have stolen some of the thunder...").

G19. Wild Pork and Watercress

Mervyn Cull. 'Top of the ridge.' NZ Herald Books and Writers 15 Nov. 1986 ("nicely crafted ...").

Garth Gilmour. Sunday Star 30 Nov. 1986: B 4 ("a rattling good yarn ... an almost unbelievable tale made believable by its raw earthiness as Crump displays his bush lore...").

Linda Sanders. Dominion Christmas Books Supplement, 5 Dec 1986:7 ("a good simple yarn").

J.N.M. 'Crump falters.' The Christchurch Star 13 Dec. 1986 ("what is lacking this time is the humour that has been so evident in his other novels. Also there is nothing really memorable about the characters he has created...").

Dave Wilson. 'Crump on the wild side.' New Zealand Sunday Times 14 Dec. 1986 ("a good yarn, though not the same jokey Crump I remember").

David Hill. Listener 21 March 1987: 56 ("...yarns on like some stubbled stegosaurus. Somewhere, some time, Crump and his crumperies crossed the border from fiction into mythology ... the characters don't go beyond emphatic caricatures.").

\section{G21. Barry Crump's Bedtime Yarns}

Iona McNaughton. Dominion 17 Dec. 1988: 9.

Dave Wilson. Dominion Sunday Times 12 Feb. 1989:21.

David Hill. Listener 15 Jan. 1990:112 ("culled from previous Crumpiana, now 20 years old, and mostly looking that way ... still upsettingly readable and interrupted by a couple of bleaker and vastly more impressive stories 'Just

Kōtare 4, no. 2 (2001), pp. 3-160. 
deserts' and "That way'... Read, and pine for a simpler age.").

W.T.M. [William Mayston?] The Christchurch Star 17 June 1989 ("...Crump remains a skilful writer, and the best straight story-teller this country has produced, the Kiwi equivalent of Australia's Steele Rudd.").

\section{G23. Bullock Creek}

Bob Pearce. NZ Herald 29 July 1989:6 ("Crump ... sometimes stretching a short story into a novel until the bones show like those of a musterer's dog ... remains a master of dialogue, but the plot and the characters seem a bit thin...").

Jack Somerville. Otago Daily Times 9 Dec. 1989:23.

David Hill. Listener 26 Feb. 1990: 112 ("the customary authoritative and episodic amble, full of sincerity, sexism and simple contentment... the writing is generally sparser and better than in Crump's previous couple. Crump bounces back.").

\section{G24. The Life and Times of a Good Keen Man}

Jack Leigh. 'From the pen of a good keen man.' NZ Herald 18 July 1992 2: 6 (profile of Crump and his books: "... His new book was not all plain sailing- It took two bursts of about six weeks which is a long time for him ..."; quotes Crump: "[In the past publishers] have been keen to grab them.. .and I've let a few books go out I'd have liked to spend more time on. These days ... I can run the trowel over my work a bit more ... 30,000 copies of Life and Times printed in Australia and 12,000 have gone to the shops ... I don't like getting to know anyone too well. Don't seem to need to. There is something wrong with all of us and I don't want to know what is wrong with anyone else. If you don't stay too long you see the best of a person...").

Michael Beckett. Wairarapa Nezvs \& Chronicle 21 July 1992: 9 ("...returns to the standard of his first effort...").

Iain Sharp. 'Right up there with the Bible.' Sunday Star 2 Aug. 1992: C 7 (".. .a much less malicious autobiographer than Frank, Janet and Lauris. His harshest comments are reserved for himself... He has an acute eye for detail and he can write superbly when he really puts his mind to it. But most of the time he doesn't bother...").

Stacy Gregg. 'Compendium.' Pacific Way. 55 (Sept. 1992): 16 (profile of Crump and the book).

\section{G25. Gold and Greenstone}

Iain Sharp. 'Good keen man loses his edge.' Sunday Star 23 May 1993 "just a

Kōtare 4, no. 2 (2001), pp. 3-160. 
pale shadow of Crump's earlier books ... Thirty-odd years ago Crump really cared about mastering the art of writing ... These days he can't be bothered ... slipshod work...").

Letter in reply by "Ron Johnson (Crump fan for many years)". Sunday Star 30 May 1993 (he, son and daughter enjoyed book).

John Stannage. NZ Herald 19 June 1993 2: 6.

Anon. Evening Post 16 July 1993 ("a piece of genuinely indigenous New Zealand folklore ... a typically Kiwi love story, except there ain't a lot of that mushy stuff...").

Graham Hemming. The Press 24 July 1993 Weekend: 10 ("continues his status as a much-loved storyteller whose simple style belies a craftsman with words").

Graeme Lay. North and South Sept. 1993:147-8 ("... a strangely childlike quality about Crump's writing, an Enid Blyton-in-a-Swanndri aspect to it").

\section{G28. Crumpy's Campfire Companion}

Craig Harrison. 'Bringing colour to the cheeks.' Dominion 20 April 1996 ("... good stuff. You can hear the spoken voice in every line ... the familiar humour ... the resilience, the optimism, the feeling you're listening to someone you'd trust...").

Warren Yardley NZ Herald 20 April 1996 (".. .a feeling of authenticity").

Glen Strange. 'Still going strong.' The Press 15 June 1996:10 ("... to fire away at the shortcomings of the writing - the cliches, the frequent vagueness of expressions - would be a cowardly act. It would also be foolish, because such 'faults' are carefully studied ... the mixture works well...").

Michael O'Leary. 'Good keen man takes some lickin." Sunday Star Times 30 Jun 1996 E 4 (".. .Like Robert Muldoon and Alan Duff, Crump tells people what they want to hear. Hence his popularity ... a genuine Kiwi literature experience. The author presents himself throughout as an ordinary, often bewildered bloke. Confronted with existential dilemma, he takes off his hat, scratches his head and says, 'Cripes, mate, gizza another beer. I'll have to think about that one'.").

Stephen Jacquiery. Otago Daily Times 6 July 1996 ("highly-entertaining").

G29. As the Saying Goes

Bronwyn Dorreen. 'Crumpisms collected.' Waikato Times 30 Nov. 1996:7 ("This collection of Crumpisms is a mixture in which Baha'i and bushman philosophy mingle easily. It's an entertaining little book of quotes, liberally laced with the

Kōtare 4, no. 2 (2001), pp. 3-160. 
dry, wry humour which was Crumpy's hallmark").

Neil Clarkson. 'Farewell to Crump.' The Press Feb. 221997 Weekend: 14 ("an easy light-hearted read").

G30. Song of a Drifter_Bronwyn Dorreen. 'Last words of a good keen man.' Waikato Times 21 Dec. 1996: 7 ("a charming postscript from a good bloke who was no mean hand at penning a ballad").

Karl du Fresne. Evening Post 10 Jan. 1997:5 ("... a poet Crump was not... trite and often contrived...").

Charmian Smith. Otago Daily Times 15 Feb. 1997:22.

Neil Clarkson. 'Farewell to Crump.' The Press Feb. 221997 Weekend: 14 ("a short enjoyable read").

\section{G31. Back Down the Track}

Anon. 'The Beauty of No 8 Wire.' Dominion 4 July 1998: 22.

Iain Sharp. Sunday Star Times 12 July 1998: F 7 (notes that only two photos have people in them; "Hogg contributes an affectionate memoir which is the single most insightful essay I've seen anywhere on Crump").

Gillian Vine. 'Focusing on Crump.' The Southland Times 18 July 1998:22 ("shows what an eye the writer had for everyday objects ... and the New Zealand rural scene. Colin Hogg's text is in Crumpese, interspersed with the real stuff from some of the 25 books Crump turned out in 36 years of writing. There are some interesting little stories about the man, such as his practice of going to bed mid-afternoon and getting up at midnight to write. Despite the quality of the photographs - and some are stunning — there's a slight bleakness in the collection, caused by the domination of the old and the tatty. Perhaps that's the darker side of the man inadvertently showing through. Shame he's not around to ask".).

Tim Wilson. Metro 206 (Aug. 1998): 101-2 ("a lavish and reverential presentation of Crump's photos [which] evince the sadness and simplicity of our abandoned great outdoors"; dislikes Hogg's "vaguely mythopoeic tone").

Kennedy Warne. Southern Skies Aug. 1998:37-9.

Nigel Yates. Otago Daily Times 29 Aug 1998: 69.

Neville Bennet. New Zealand Books 9,2 (June 1999): 11

G32. The Pungapeople of Ninety Mile Beach

Kōtare 4, no. 2 (2001), pp. 3-160. 
Trevor Agnew. Magpies [Perth] 14,5 (Nov. 1999) New Zealand Supplement: 7. Unseen.

\section{H. References to Crump in Books, Articles, Television, Radio}

H1. Crump appears in a number of biographical and literary reference works including: Authors and Writers Who's Who 1963, 1971; International Authors and Writers Who's Who 1976, (not in 1982), 1991, 1993; Dictionary of International Biography 9th ed., 1973; Writers Directory 1976-8, 1982, 1984, 1986,1988,1990,1992,1994; Notable New Zealanders, 1979; Who's Who in New Zealand 7th ed., 1961 ("...compiler of fantasies ... of no fixed abode"); 8th ed., 1964; 9th ed., 1968; 10th ed., 1971; 11th ed., 1978 ("no private, or permanent address"); 12th ed., 1991; New Zealand Who's Who Aotearoa, 1992.

H2. Crump's Australian sojourn and stories win him an entry in John Arnold and John Hay, Ed. The Bibliography of Australian Literature, A - E. Kew, Vic: Australian Scholarly Publishing, 2001.

H3. He has an entry in Contemporary Authors, New Revision Series Vol. 8. Detroit: Gale Research, 1983 (earlier in Vols.13-14,1965 and 15-16,1966; and in Vols.13-16 First Revision, 1975); also in Contemporary Authors Online. 2000.

H4. The University of Auckland Library's 'New Zealand Literature File' includes a primary and secondary bibliography of Crump at $<$ http://www.auckland.ac.nz/lbr/nzp/nzlit2/crump.htm> ("includes published material to February 2001"; viewed 30.9.01).

H5. There is a brief biography at a New Zealand Folk Song site at $<$ http:/ /www.mcs.vuw.ac.nz/ lindsay/NZ-Folk/blackmat.html\#CRU> (viewed 30.9.01); and another at

H6. 'Wordman's Home page' < http://www.wordworx.co.nz/ crump.html> (viewed 26.9.01); and

H7. an entry for him (between 'Cromwell, Thomas, (cl485-1540) Principal minister under Henry VOL' and 'Curtiss, Glenn Hammond, (1878-1930) Pioneer aviator in USA. Aileron inventor. Bicycle mechanic.') in the Working Class Encyclopedia published by The People's Embassy, Christchurch, at $<$ http://Viammer.prohosting.com/ penz/encycl/copedia.htm> (viewed 21.9.01).

H8. Autograph collector Gregor Ronald has posted a copy of Crump's signature at $<$ http://cartman.inet.net.nz/-gregor/autographs/aiitograph2.html> (viewed 


\subsubsection{1).}

H9. At Neika Stud in Tasmania stands Cleveland Bay stallion Wetherby Barry Crump, 16.2 hands, "born in New Zealand of pure-bred imported parents"; details of his offspring are on their web page $<$ http://www.tassie.net.au/ jgoldfin/> and a picture can be seen at $<$ http://www.bpstud.com.au/art8.lttml > (both viewed 8.10.01).

H10. 'Three grants from Literary Fund made.' Auckland Star 18 Jan. 1961 ("...£150 to Barry Crump of Taupo to assist him in writing a novel. Mr Crump's first book, 'A Good Keen Man', was published recently ... Anton Vogt... Marilyn Duckworth..."). Crump told a later interviewer he spent the "pathetic amount" shouting drinks in a bar one afternoon (Ivan Agnew $\underline{\mathrm{H} 67}$ ).

H11. Anonymous article (editorial?) NZ Listener 21 April 1961: 3. Long discussion of Crump and A Good Keen Man, which was read on radio beginning 26 April 1961.

H12. $\quad$ NZ Listener 2 June 1961: 12 (with port.). Crump interview by Prudence Gregory to be played on Saturday Night at Home on 10 June 1961; the article quotes some of Crump's comments ("... I grab a pencil when there's nothing else to do and write...").

H13. The interview provoked a series of letters in the NZ Listener all under the heading 'A Good Keen Man': J. Holdom 21 July 1961 pp.28-9 complaining about Crump's English ("One presumes he was never taught to speak English ... one does not expect to hear 'Oi'll soey: Hellava Jorb', and 'boozer' ..."); replies 4 Aug. p.28 by James K. Baxter (defending Crump); 18 Aug. p.28 by Phyl Ferrabee (defending Crump), Norman F. Daniels (criticising Baxter); Aug. pp.32-3 by Holdom (criticising Baxter), E.J. Williams (Crump's language "a breath of fresh and salty air" but not suitable "for the communication of less earthy sentiments ... A Good Keen Man shows ... sustained first-class writing of the strictly non-colloquial variety") and A.W. Bullen (criticising Baxter); 1 Sept. pp.28-9 by T.R. Livesey ("New Zealand accent ... an ugly and harsh dialect...") and Baxter (poem, employing the word 'boozer'); 29 Sept. p.29 by Michael Young, "Eyes Open", and "She's Right". (All except the last three are reprinted in New Zealand English Newsletter 4 (1990): 35-8.)

H14. NZ Listener 9 June 1961: 34 (review of the broadcast of the first episode of $A$ Good Keen Man — very favourable and praises Bernard Kearns's reading "How I wish, though, that the author had been persuaded to read the book to us himself": see $\underline{\mathrm{H} 144}, \underline{\mathrm{H} 310})$.

H15. Jackson Horner. 'Talking books — A Good Keen Man.' Nezv Zealand Holiday 2, 2 (June 1961): 28-9 (discusses A Good Keen Man and Hang on a Minute Mate in the context of the use of humour and the vernacular in New Zealand fiction;

Kōtare 4, no. 2 (2001), pp. 3-160. 
A Good Keen Man "the first time anyone has seriously tried to tap the rich field of back-country life to produce a comedy of manners and social life ... a romantic and idealistic work in the sense that its hero sentimentalises about nature, and as a hunter is preoccupied with the simple values of a life which is now anachronistic and meaningless to nine-tenths of the present-day population ... Crump is writing inside what remains of the old Australasian frontier tradition ... [he] is dominated by the Victorian 'bush' school of writing and owes much to ... Lawson, Ogilvie, Steele Rudd and Dennis ...").

New Zealand Holiday magazine, published by the New Zealand Travel and Holiday Association, was publishing at this time a regular series of articles by Graham Kerr on New Zealand food and dining: I am told that Crump was asked to do a companion series on bush cooking and that this suggestion was not welcomed by Kerr. A search through the magazine shows no Crump articles were published.

H16. Joan Stevens. The New Zealand Novel 1860-1960. Wellington: A.H. \& A.W. Reed, 1961; reprinted 1962, 1964. 136pp.: Crump p.47 ("somewhat comparable" to Frank Anthony). Second edition 1966 (ㄴ1ㄴ).

H17. Television interview by Ian Johnstone on Close Up 1961? (145).

H18. "'Good Keen Man" has "retired".' NZ Herald 1 Feb. 1962: 3 ("...Mr Crump admitted that he has 'pots of dough'. He made a few thousand last year and it would be more this year. Four English and four American publishers were seeking publishing rights ... working on his third book, to be titled perhaps, 'Situations vacant' ...").

H19. 'Partnership for "Good Keen Man".' NZ Herald 2 Feb. 1962: 1 (marriage to Fleur Adcock).

H20. 'N.Z. author weds poetess.' Weekly News 21 Feb. 1962 (with photo of Crump and Fleur in Land Rover, and the quote: "I don't understand her poetry and she doesn't like my books"). This article is reprinted in $\underline{\mathrm{H} 151}$ and the photo reproduced in $\mathrm{H} 210$.

H21. 'A Good Keen Pig Dog. Barry Crump talks to Bruce Murphy.' NZ Listener 19 April 1962: 5 (with photo of dog). Interview from 'Open Country' radio programme. This is reprinted in Jim Henderson, Ed. Open Country, People and Places out of Town. Wellington: A.H. \& A.W. Reed, 1965 (즈).

H22. 'Bankrupt given discharge.' NZ Herald 28 July 1962: 6 (Crump had declared himself bankrupt in the 1950s).

H23. 'N.Z. Books Among the Best-Sellers.' Evening Post 17 Sept. 1962: 14 (quotes Ray Richards of Reeds: "After sales of almost 100,000 copies in New Zealand 
in less than two years Barry Crump is having one of his books published in London shortly. Continental and American rights are now being negotiated").

H24. Ian Templeton. 'On walkabout with Barry Crump.' Auckland Star 28 Sept. 1962 ("Barry Crump ... whose first two books laid the country's publishing trade on its ear, has gone walkabout ... shooting crocodiles somewhere in the Gulf of Carpentaria"; quotes Crump's adventures from "a letter to his publisher" ... '...I have started already on another book, about ingen-iousness'...").

H25. 'Now he's hunting crocodiles.' Auckland Star 13 Nov. 1962 (Crump "now a serious crocodile hunter", has bought a sloop, the Water Witch).

H26. Anon. 'A good keen woman.' Cappicade 1962: 51-4. A parody with 3 illustrations by Ivan Cash, one a caricature of the dust-jacket of the book showing a hanged bearded man with noose around neck, 'Hang on A Minute Mate! by Hairy Stump'. The editor, Con O'Leary, says (letter 24.9.01): "I cannot remember with absolute certainty who wrote the ... piece ... I think it was probably Paul Grey ... The only other possible alternative could have been an anonymous contribution from Jean Watson".

H27. Maurice Duggan. 'Along Rideout Road that summer.' Landfall 65 (March 1963): 8-24 (reprinted in Summer in the Gravel Pit. London: Victor Gollancz, 1965; also co-published by Blackwood and Janet Paul, New Zealand, 1965; reprinted by Longman Paul 1971,1973,1978; included in Collected Stories. Edited and Introduced by C.K. Stead. Auckland: Auckland University Press; Oxford University Press, 1981; much anthologized). Duggan's character describes a laconic exchange as "a genuine crumpy conversation", on which C.K. Stead comments: "in that gibe at a fellow-author (Barry Crump) Duggan dissociates himself from the line of New Zealand fiction which has gone in for the realism of inarticulacy" - Collected Stories, introduction, p. 13; Stead's essay is reprinted in his In the Glass Cage, Essays on New Zealand Literature. Auckland: Auckland University Press; Oxford University Press, 1981. Pp.10721. An online "Teachers and Senior English Student Guide to Along Rideout Road That Summer..." by David Dowling at $<$ http://210.54.120.116/English/Duggan.htm> (viewed 9.10.01 in cache at www.google.com) glosses 'crumpy' with: "Barry Crump published A Good Keen Man in 1960. It was widely read in New Zealand, and put forward the idea of the laconic but goodhearted New Zealand 'joker,' more at home in the back blocks than in the city or in company.".

H28. Fleur Adcock. Poem 'Cold moon shining.' Landfall 65 (March 1963): 26 ("which Maurice Duggan happily assumed to be an attack on Barry Crump" Ian Richards, To Bed at Noon ( $\underline{\mathrm{H} 258})$ p.306); poem reprinted in The Eye of the Hurricane (Wellington: A.H. \& A.W. Reed, 1964), p.34; not reprinted in her later collections.

Crump is unmentioned in her autobiographical essay 'Beginnings' in Islands 26

Kōtare 4, no. 2 (2001), pp. 3-160. 
(Aug. 1979) but there is a brief allusion in her essay 'A lifetime of writing' in Margaret Clark, ed. Beyond Expectations: Fourteen New Zealand Women Write about their Lives. Wellington: Allen \& Unwin / Port Nicholson Press, 1986. 0868616508. 205pp. Pp.98-111 — "1962 was a year of drama and confu-_sion: I fell into a brief, ludicrous and doomed second marriage" (p. 107). A longer autobiographical essay in Contemporary Authors vol. 182. Detroit: Gale Research, (C2000 (not included in Contemporary Authors Online) pp.6-19 devotes a paragraph to Crump: "...In January 1962 I met Barry Crump, a bestselling author of picaresque, anecdotal sagas about deer-culling, rabbit-shooting, and life in the bush or the pub, told in the casually colourful Kiwi male vernacular: not my kind of literature at all, nor my kind of man. A month later ... we were married. This was lunacy ... A year of confusion and melodrama followed ...black eyes, bruises, and chipped teeth..." (p.14). Her most personal comments on her relationship with Crump appear in an interview with Sally Vincent, 'Final Touch', in The Guardian 29 July 2000 (available online at <http://www.guardian.co.uk/weekend/story/n,3605.348037.00.html>: viewed 8.10.01): "...[After she settled in Dunedin] Well-meaning friends, perceiving her anguish, introduced her to various distractions, among them a gentleman by the name of Barry Crump. 'But don't marry him,' they counselled urgently, which was a mistake. Among his many distinctions, Mr Crump was incredibly famous in New Zealand. Searching for a contemporary equivalent, Adcock thinks of Georgie Best. Or, better yet, Gazza. He was a Crocodile Dundee sort of fellow who wrote adventure stories with titles such as Hang On A Minute, Mate and A Good Keen Man. And, of course, he was an absolute knock-out in bed. 'Well, they are, aren't they?' she says, giggling like a teenager. 'Male chauvinist pigs always are. Think of Italians. Isn't it perverse?' Anyway, it wasn't long before she displayed all the foresight and prudence of a lemming and married him. It was, she says, the most horrifying thing she could think to do to persuade herself out of more obsessive liaisons. He was soon routinely smacking her in the mouth. 'They do that, don't they?' she says. 'Manly men. They're fine in the pub telling jokes and stories, but in an argument they're not so good at the old logic, so that's when they smack you across the mouth.' The marriage lasted five months. By way of a divorce settlement, Mr Crump agreed to pay her passage to England, less the $£ 30$ she'd already salted away for the purpose ...".

She agreed to take part in a discussion on Crump with Kevin Ireland and Colin Hogg at the Going West Books and Writers Festival in Auckland Sept. 14-16 2001 (H321; "I must have been mad to agree to it...": Iain Sharp 'Against coupling' Sunday Star Times 26 Aug. 2001: F 1, with heading "New Zealand's most celebrated literary expatriate ... is in Auckland next month to talk about her tempestuous early life..."); see also Margie Thomson, 'Something_ about Fleur,' Weekend Herald Sept. 15-16 2001: E 6.

H29. Coverage of Crump's shipwreck and rescue in Australia in 1964 has not been traced: Crump in Life and Times (p.117) talks of "about twelve reporters" (one from the South Pacific Post, Port Moresby) interviewing him and his rescuers on their arrival in New Guinea. "... news of my rescue ... reached New Zealand. There was quite a splash in the press about it..." (Life and Times p.119) at the

Kōtare 4, no. 2 (2001), pp. 3-160. 
very time Gulf'was launched and Crump was accused of staging the shipwreck as a publicity stunt. "...Crump made the headlines but the stories were slanted in such a way to suggest that he had been left marooned by a companion. The papers had another story when the companion correctly pointed out that he had not deserted Crump..."; Crump's companion believed Crump had accused him of abandoning him and "it was this experience which made Crump suspicious of journalists" (Ivan Agnew, Sunday Nezos 3 June 1973: 24; H67). Crump got his revenge with his satire "No Reference Intended".

H30. Ron Helmer. Stag Party. Christchurch: Whitcombe \& Tombs Ltd, 1964. (See C2: Crump is a character in the book and wrote a foreword to it.)

H31. Anthony Nolan. Bush Singalong: Songs of New Zealand Trampers, Hunters, Mountaineers, Skiers, Scouts, etc. Written, composed, collected and adapted by Tony Nolan. Kiwi record LC-11 [1964], 12 inch, LP, 331/3 rpm. Includes two songs by Nolan "'A good keen man' and its complement 'A good keen woman' [which] could be said to have been inspired by Barry Crump's best-selling book about New Zealand hunters and bushmen" — sleeve. (Copy held at ATL.)

H32. Wally Crump. McDunnit Dunnit. Auckland: Ace Distributors, 1964. 176pp.

Novel by Crump's father, first published Sept. 1964, reprinted Nov. 1964.

Some of his stories were printed in the Sunday News (Hogg Loose Strides p.129). The dust-jacket flap of the 2nd impression quotes the NZ Herald review: "It is inevitable that Wally Crump's style will be compared with that of his son, Barry, but his father can stand on his own feet. He has produced a quietly written account of country life that is less lurid in language than his son's but every bit as entertaining...".

Wally Crump was, among much else, a bookseller and receives two para_graphs in Anna and Max Rogers, Turning the Pages, The Story of Bookselling in New Zealand, Auckland: Reed Books, for Booksellers New Zealand, 1993: "His bookselling career was brief, but for sheer originality and a certain pragmatism of approach former blacksmith, pig hunter, jockey, farmer and novelist Wally Crump ... was a hard man to beat... Wally also wrote a novel, McDunnit Dunnit, about the 'old cow cockie times' and based on his farming experiences in the 'good old tough days', as he told the Auckland Star ... A second title, McDunnit Wunnit, was in the pipeline ..." (p.47). The quote is from 'Wally mans a counter', Auckland Star 9 Feb. 1972; there is a profile of him in The Central Leader 8 Dec. 1971: 5 ("Mr Crump says that he has written another book which will be published shortly") and an article 'So whodunnit? Crump's stumped', Auckland Star 25 Jan. 1972, reports the shop being mysteriously found open when he was away. Hogg Loose Strides p.106 notes the second novel, rejected by Reeds, and at the launch of Wild Pork and Watercress ".. .lapping up the attention, Wally reminded everyone he too had knocked out a book. The book had been on the best seller list for six months in the mid-sixties. He'd written it because Barry

Kōtare 4, no. 2 (2001), pp. 3-160. 
had bet him \$5 he couldn't. There had been another one from his pen about parliamentarians - but a newspaper lost the manuscript and he'd not bothered to try again ..." (Jill Nicholas Sunday News 16 Nov. 1986: 5; $\underline{\text { H129)}}$ ).

H33. M.D. Cranko. Letter 'The sand mullet.' NZ Listener 24 Sept. 1965: 11 on the strong resemblance of Crump's story 'The wonderful West Coast sand mullet' to Dal Stivens's story 'Sammy the Sand Mullet' (see $\underline{\text { A8 }}$ ).

H34. Jean Watson. Stand in the Rain. Christchurch: Pegasus Press, 1965. 150pp. (U.S. edition Indianapolis: Bobbs-Merrill Co. (C1966; new edition with introduction by Linda Hardy, Wellington: Allen \& Unwin / Port Nicholson Press, 1986, 0868616028; Dutch translation: Staan in de regen. Utrecht: A.W. Bruna \& Zoon, 1969; film rights were sold - "An American film company is to make a screen version ... Cinema Centre Films by arrangement with Wizen Productions plan to film this contemporary story of young love..." noted Pegasus Press's 1972 catalogue — but plans fell through. Novel ("... the woman's side to a New Zealand legend. Here is the girl behind the good keen, deer-killing, possum-trapping, pig-hunting, rabbit-shooting, scrub-cutting, hardcase, dinkum-type Kiwi...": blurb) by a former partner of Crump, who is the basis of the character Abungus Gill ("Yeah you could say to a certain extent [Abungus is] based on Barry Crump" — Watson_quoted NZ Outlook April 1987 (H137); "she wrote a book about our adventures" (Life and Times p.121); a Reed letter (26.5.70, ATL-MS-Papers 6548) assured Crump's then agent "[her] new book doesn't concern Barry at all... The old book ... had a Barryesque figure and it is in fact based on Jean's early association with him ten years ago, when they were bumming round New Zealand together"; "Barry Crump, Watson readily admits, is the model for the scrub cutting guitar playing Abungus" (John Saker, 'At the writer's desk', interview with Watson, Wellington City Magazine July 1985: 70). In an interview (Jill McCracken 'Life is just things that happen' NZ Listener 3 July 1972: 14-15) Watson described the book as "partly my own experience and partly other people's and partly imagination. I think that's what most books are...'; Anne Kennedy Listener 21 June 1986: 49, reviewing the 1986 edition issued to coincide with the publication of Address to a King, concludes: "It doesn't matter whether Barry Crump was the model for Abungus, or not -the only relevance is that Jean Watson was living in an age of good keen boys".

Reviewed by D. Hall NZ Listener 12 Nov. 1965: 18-19; by Margaret Orbell in Te Ao Hou 53 (Dec. 1965): 56; and anonymously in Fernfire 13 (Dec. 1965): 33 ("perhaps for the first time in New Zealand literature, describes the life and emotions of a woman who is in love with a man who has fled responsibility and the city life...").

Aorewa McLeod, 'A single woman's search', New Zealand Books 13, June 1994: 7-8 calls the book "an evocation of the sixties. This, I'm sure, is why it was republished in 1986 ... nostalgia...". Marilyn Duckworth, "Top of the list for Christmas. Dominion readers pick the books they most enjoyed this year', Dominion Dec. 6 1986: 11 praised this "reprint of a delightful novel which

Kōtare 4, no. 2 (2001), pp. 3-160. 
slipped by us fairly quietly in 1965 ... This novel charms us by its unselfconscious simplicity and natural dialogue. The young woman narrator's disappointments and hopefulness touch us like life itself". Reviewing the reprint and Address to a King in The Press 31 May 1986: 20, Diane Prouit noted that "...The randomness of circumstances which brings unlikely people together and sets them off on a sequence of events is the basis of both books...". John O'Shea (Don't Let it Get You, 1999, p.36; $\underline{\text { H133 }}$ ) finds Crump in both Stand in the Rain and Address to a King, calling them "lyric and loving testimonies to the rough and ready style of life with him". Watson talked at length of her relationship with Crump in an interview with Molly Anderson, 'Vision which grows brick by brick', Otago Daily Times 10 April 1999 (available online at $<$ http://www.odt.co.nz/?issue=1999/-_lQAprl999> under 'Features': viewed 27.9.01): "... Jean's life has been marked by improbable encounters. One of the first was Barry Crump ... she was going nowhere. Then, along came the young man of her first novel, Stand In The Rain, who 'played the guitar like a Maori and had a face like the god Pan'. The attraction was instant and mutual. 'We had a lot in common: a mixture of naive optimism and a taste for adventure. We didn't live in the bush like Tarzan and Jane as some seem to think, but we liked camping out, taking off for different places. We were always following some dream of an ideal existence without being quite sure what this was ...". See also Jane Tollerton, 'Telling an 'amoral tale', NZ Woman's Weekly 30 June 1986: 18; Hogg Loose Strides pp.90, 95-6; Maurice Shadbolt From the Edge of the Sky, A Memoir; $\underline{\text { H287). }}$.

H35. Maurice Shadbolt. Among the Cinders. London: Eyre \& Spottiswoode, 1965. 301pp. (NZ edition: Christchurch: Whitcombe \& Tombs, 1965; US edition: New York: Atheneum, 1965; reprinted with introduction by Stephen Becker, Christchurch: Whitcoulls, 1975 [i.e. 1976], 0723304564; revised edition: Auckland: Hodder \& Stoughton, 1984, 0340348178; reprinted Auckland: Sceptre NZ, 1993, 0340348178; German translation by Helmut and Christel Weimken: Und er nahm mich bei der Hand. Hamburg: Hoffmann und Campe, 1970,3455072100. 295pp.; 2nd ed., 1970; reprinted Reinbek bei Hamburg: Rowohlt, 1973 (rororo 1589; 3499115891) and 1985 (rororo 5439; 3499154390).

Chapter 26 of the novel describes a literary party in Auckland with Shadbolt himself among the guests, together with (unnamed but artfully delineated) Ian Cross, Denis Glover, James K. Baxter, and Crump ("a really hairy fellow ... a deer-culler when he wasn't writing about shooting deer... he explained to me a technique for killing wild pigs with gelignite... just what you might expect from some literary friend of Derek's..."). In the revised 1984 edition (and already in the 1970 German translation) the party is in Chapter 25, the "deer-culler ... shooting deer" description has gone, and he is now a "lazy literary friend". (See also Lawrence Jones, 'Out of the swamp and into the rut, The paradoxical progress of Maurice Shadbolt' in Ralph J. Crane, ed. Ending the Silences: Critical Essays on the Works of Maurice Shadbolt. Auckland: Hodder Moa Beckett, 1995.) Among the Cinders was filmed - or rather a film was "based on the book" — in 1983, screenplay by Rolf Haedrich (director) and John

Kōtare 4, no. 2 (2001), pp. 3-160. 
O'Shea (producer), but the party scene was omitted.

H36. Barry Shaw. On My Screen. 'Lifesaver Crump is called in to rescue.' Auckland Star 1 June 1966. ("... The services of this champion of the New Zealand vernacular have been called in to resuscitate AKTV2's ailing children's hour programme 'Yo Heave Ho.'..."; Crump both a script-writer and one of the characters; "an important development. Here for the first time we have a New Zealander, writing in the New Zealand idiom, for a New Zealand show...").

H37. Note in Auckland Star 31 Dec. 1966 quotes David Pardon, NZ Woman's Weekly TV critic, deploring "the sweeping and general vituperation being heaped on that glorious Kiwi character Barry Crump": "His sense of humour is fabulous ... Barry Crump has shown us a Kiwi is able to laugh at himself".

H38. ' 'Out of town? No, just out of sorts.' Auckland Star 19 July 1966 (Crump not on Town and Around in his "Wednesday spot" due to illness - "it must be a germ with a punch to send the massive Crump frame to a sickbed ... he is being missed. Crump is learning fast about the television game..."; further notes: Tacked off Auckland Star 2 Aug. 1966 ("back in action"); 'Crump under a cloud' Auckland Star 22 Sept. 1966 ("...last night he made his first appearance for some time - and brought to life Tom Finlayson's poisonous plants story. Now he is sick again... tonsillitis...").

H39. 'Records of books for blind.' NZ Herald 30 July 1966 ("The author Barry Crump made his contribution to Braille week yesterday by starting to record two of his books...").

H40. A.W. Reed. Books Are My Business, The Life of a Publisher. Reading (England): Educational Explorers Limited, 1966 (My Life and My Work Series). Plates. 131pp. Crump pp.58-9 ("A Good Keen Man" and "Hang on a Minute Mate" as "outstanding" titles for books, the former "has become a catch-phrase"); p.87 (publication of A Good Keen Man, "a break-through which showed that a New Zealand book could outsell a British or American bestseller in our own territory ...[it] had sparkling wit and characterisation in its pages").

H41. Joan Stevens. The New Zealand Novel 1860-1965. Second edition revised to 1965. Wellington: A.H. \& A.W. Reed, 1966.159pp. Adds to first ed. (116) "has continued his headlong hardcase Kiwi career" (p.116).

H42. D.O.W. Hall. Article 'Literature' in A.H. McLintock, ed. An Encyclopaedia of New Zealand. Wellington: Government Printer, 1966. Short paragraph on Crump vol.2 p.533 ("...its vivid rendering of the local patois, its gutsy comedy, and its original material").

H43. "Konstant Le Booze" (pseudonym of Duncan Simpson). 'Crump ... Man or

Kōtare 4, no. 2 (2001), pp. 3-160. 
H44. The House of Reed 1957-1967. Wellington: A.H. \& A.W. Reed, 1968. Plates. 115pp. Lists the number of Reed printings of Crump's books; plate facing p.47 shows a New Plymouth bookshop window with display of Gulf and large poster of Crump; p.63 photo of Crump; p.79 two of his books among Reed bestsellers.

H45. J.C. Reid. 'Literature' in A.L. McLeod, ed. The Pattern of New Zealand Culture. Melbourne: Oxford University Press; Ithaca, N.Y.: Cornell University Press, 1968. Pp.17-48: brief mention of Crump p.34 ("...the simplified image of the hard-doing Kiwi joker as epitomized in ... A Good Keen Man").

H46. A series of newspaper articles reported the death by drowning on 4 Sept. 1969 of five boys attending a camp organised by Crump and George Johnston, the inquest, their subsequent deposition for manslaughter, and the dropping of the charges six weeks later:

'Boys drown when adventure camp truck dives in lake' (with photo of Crump and Johnston) Auckland Star 5 Sept. 1969; 'Charges over lake tragedy' Evening Post 12 Dec. 1969; "T tried to help," 13-yr-old tells Whakatane court' Auckland Star 5 Feb. 1970: 1; Evening Post 5 Feb. 1970: 16; 'Bush camp men sent for trial after 5 deaths' Auckland Star 6 Feb. 1970; Evening Post 26 March 1970: 16; 'Charge against Crump, Johnston is thrown out' Auckland Star 26 March 1970: 26.

H47. 'Speeding fine.' Auckland Star 12 Sept. 1969 ("Barry Crump (34), guide of Te Teko, was fined $\$ 30 . . . ")$.

H48. Robert Gilmore. Give and Take. 'Crump writing full-time.' Auckland Star 30 May 1970 (A Good Keen Girl soon to be published; Crump "New Zealand's most successful author by far, with total sales well beyond half a_million including more than 100,000 for the Russian edition of A Good Keen Man" [sic; see Bl]; holed up at Te Teko writing "No Reference Intended").

H49. This Day Northern Television 27 July 1970 ("Interview with author Barry Crump about his latest book 'A Good Keen Girl'": New Zealand Television Archive).

H50. Sunday Times Aug. 1970: Crump included in list of "My Twenty Most Important New Zealanders" by Spiro Zavos.

H51. 'Book Week' On Camera Northern Television 20 Oct. 1970 ("Hamish Keith takes a look at New Zealand books and their readers with comments from Barry Crump, Maurice Shadbolt, John Reid and Graham Townsley": New Zealand Television Archive).

H52. P. Saffery. 'Introduction to and translation of an afterword by V.M. Bakhta to the Russian edition of Barry Crump's 'Gulf'.' New Zealand Slavonic Journal 5

Kōtare 4, no. 2 (2001), pp. 3-160. 
H52. P. Saffery. 'Introduction to and translation of an afterword by V.M. Bakhta to the Russian edition of Barry Crump's 'Gulf'.' New Zealand Slavonic Journal 5 (Winter 1970): 25-32 (see $\underline{\text { B6}}$ ).

H53. Frank Sargeson. 'Conversation with Frank Sargeson, An interview with Michael Beveridge.' Landfall 93 (March 1970): 4-27 and 94 (June 1970): 142-60; reprinted in Kevin Cunningham, ed. Conversation in a Train and Other Critical Writing. [Auckland]: Auckland University Press; Oxford University Press, 1983. 019648023X. 220pp. Crump: p.152 (position of writers in New Zealand "quite different from Australia ... they're not tolerated here ... Crump ... has remedied this, but of course he's fortunate that he's also made it pay off which makes it respectable anyhow"); p.156 ("to be a writer, unless you're a primitive or virtually a primitive like Barry Crump, you're tremendously well read..."); p.183 ("Oh. I can't claim to have helped Crump. My intentions were all right but they never came to anything").

H54. Jacquie Billson. 'and now a word with the good keen Crump.' Thursday 29 Oct. 1970: 18-19. Interview after launch of A Good Keen Girl and his record 'Bad Blue' (see El). Quotes Crump: "...I'm married now ...third time ... she's a good strong healthy woman; these good lookers are too fragile ... If I want to play around with a woman I do. But I'm honest about it. I just tell her that I met this bird and she was attractive, intelligent and great and we made love and it was marvellous. And my wife calls me a slob and says 'You_know I can make love to you better than anyone else. Well, you'd better go and have a bath'. It's very important to be honest...".

H55. This Day Northern Television 15 Feb. 1971: "A look at British actor Warren Mitchell with New Zealand writer Barry Crump" (New Zealand Television Archive).

H56. Terry Bell. 'Good, keen bloke a TV producer.' 8 O'clock 13 Nov. 1971. Interview: plans for Hang on a Minute Mate television series; Crump on cities ("I can't stand the idea of more than one day at a time in Auckland"), protesters, politicians, unions, security ("If you buy a house ... it's a stone round your neck"), academics ("part of the biggest con game in the country"), writing ("I've got a feeling ... that when I'm 40 I'll write a really good, significant book. But I'm not writing for posterity")...

H57. 'My oath! It's Barry's mad bastard mod..!'. Sunday News 21 Nov. 1971: 1, 9 (front page announcement of forthcoming series of extracts from Bastards I Have Met with comments on the book).

H58. Geoff Sinclair. 'Crump and beer equal interview smozzle.' Sunday News 28 Nov. 1971. Interview — "Don't ever interview Barry Crump in a hotel bar..." — why he wrote Bastards; publishing it himself; short extract; joined by George Johnston ("a sort of Crump Mark II"). Extracts from the book ("specially edited", and with extra material not in the book) appeared in the issues for 5

Kōtare 4, no. 2 (2001), pp. 3-160. 
a puzzly bastard').

H59. 1971 interview with Judy McGregor (Sunday News?) (quoted Hogg Loose Strides p.127).

H60. 'Christmas.' Survey Northern Television 21 Dec. 1971 (Crump among those talking about the meaning of Christmas: New Zealand Television Archive).

H61. 'Good keen man defies publishers and makes it alone.' NZ Herald 30 Dec. 1971: 3 (see $\underline{B 12}$ )

H62. Frank Fyfe. 'Timber.' The Maorilander, Journal of the New Zealand Folklore Society 3 (Winter 1971): 21-36. Pp.25-6 quote Crump's version of the song 'Timber' and his comments on its origin among mainly Maori bushmen between 1947 and 1949; Jean Watson also quoted.

H63. Austin Mitchell. The Half-Gallon Quarter-Acre Pavlova Paradise. Illustrated by Les Gibbard. [Christchurch]: Whitcombe \& Tombs Limited [1972] (0723303495). 184pp. Pp.152-4 'The Kulture of the Kiwi Bird': "Kiwi humour comes in many forms: Crump, Crumpette, The Kiwi Laughs, Hansard ... All skilfully blend the tragic vision of P.G. Wodehouse with the comic sense of Emily Bronte. They achieve their point by manipulation of stereotypes ... Most are paternalist, except for Crump, the very best of them and the only man to emerge from the back-blocks who can actually write. He retells, in vivid vernacular, tales that are legend in the bush ... Crump strikes just the right note for his countryman's sense of humour. His book output keeps neck and neck with Apollo launchings."

H64. 'Leisure' Survey Northern Television 18 Oct. 1972 (Crump included in this "look at the changing relationship between work and leisure activities in New Zealand society": New Zealand Television Archive).

H65. 1972 article in Sunday Herald on Crump and the soon to be published Fred (quoted Hogg Loose Strides p.129).

H66. Anne Marie Nicholson. 'Meet Crump. He's really a nice bunch of chaps.' Sunday Neivs 17 Dec. 1972: 33. Interview. A six part series of extracts from Fred began in the following issue.

H67. Ivan Agnew. 'Goodbye Crumpy. He's off to find God.' Sunday News 20 May 1973:1,4 (Crump leaving for India). In the same issue appeared the first of a series of interviews with Crump (with many photographs) by Agnew who stayed a week with Crump and Vanda; the series has much on Crump's early life and his first steps as a writer: 20 May 1973: 24-5,37 (Tvan Agnew meets the man behind the man. Is he an artist or just a con man?'); 27 May 1973: 26-7, 38 ('... No rough and ready guy'); 3 June 1973:1 (son Harry by Jean Watson), 22-4

Kōtare 4, no. 2 (2001), pp. 3-160. 
man behind the man. Is he an artist or just a con man?'); 27 May 1973: 26-7, 38 ('... No rough and ready guy'); 3 June 1973:1 (son Harry by Jean Watson), 22-4 ('Part Three: "I feel like some sort of idiot"'); 10 June 1973: 24-6 ("I am going to cry out: 'Take me God!"'; tractor given to Michael Illingworth; Crump's views on what's wrong with society and the education system).

H68. Ivan Agnew. 'Crump finds God.' Sunday News 21 April 1974:1 (front page article on Crump becoming a Baha'i); Crump's own account, 'Crump — I've tried it all' p.21.

H69. Hone Tuwhare. Something Nothing. Poems by Hone Tuwhare. Graphics by Robin White. Dunedin: Caveman Press, 1974. 47pp. Poem 'Beachcomber interviewed (to Barry Crump)' p.18.

H70. Bob Lowe. That's Me Without the Tie. Christchurch: Whitcombe \& Tombs Ltd, 1974 (0723304149). Ills. 193pp. Crump pp.186-7: introduced by Lowe on radio talkback as "The Reverend Barry Crump".

H71. Edwards on Saturday TV1 10 July 1976. Crump and friends interviewed by Brian Edwards; his marriages, his new celibate Baha'i lifestyle ("sex is a drag") with Margot who describes him as "a man of extremes"; "Barry Crump has a hunger ... a loneliness ... only the ultimate reality will do", says Jean Watson; "Crump was always slightly phoney, but acted well", says a friend; Crump agreed. (Held by New Zealand Television Archive.)

H72. David Ballantyne. 'Crumpie all serenity.' Teleview. Auckland Star 12 July 1976. Review of Edwards on Saturday: "Barry Crump still tells a good yarn ... that one about the bloke turning cartwheels on a fence after his mate accidentally hit him with a pickaxe handle. Vintage Crump that yarn ... Mostly, though, Crump was plugging the Bahai line. He appeared to mean every word of it..."; also reviewed by Kevin mcMenamin, 'Meeting the new Barry Crump,' The Press 12 July 1976:15.

H73. Bob Lowe. Letters to John. Christchurch: Whitcombe \& Tombs, 1976 (0723304726). 121pp. Crump p.56: "Barry Crump exploded into my life one day in a burst of booze, bawdy ballads and boisterous behaviour. I happen to admire him tremendously and value him as a friend ... Get hold of A Good Keen Man. It will explain much in New Zealand life which is at present puzzling".

H74. Robyn Langwell. 'Good keen man spends time spreading the good word. Barry Crump is alive and well and living in Oratia.' NZ Herald 29 Jan. 1977: 2: 2 (Interview with "the dinkum Kiwi writer who dropped out of the limelight in 1972" ... "Crump is still Crump, rolling his own, spitting to-_bacco, and talking about 'chicks' but his heart is in a different place now — so he assures us ... 'Writing was terribly important for me and still is, but I've got to be in the mood ... I'd be terribly happy to write again, but I'll just sit and wait for it to 
name ever does grace the bookstalls again, there will be a few noticeable changes in writing style. They'll be no more backbiting and criticising ... that was pretty ignorant of me").

H75. ' 'Barry Crump.' Good Day TV1 17 March 1978 (Crump living in Moa Flat Creek area, near Queenstown, sick of town life and the publicity, possum hunting, whitebaiting and gold digging: New Zealand Television Archive).

H76. 'Search for Barry Crump.' Good Day TV1 11 July 1978 ("Reporter goes into the hills behind Queenstown to find Barry Crump to see how he's coping with the Central Otago winter, but gets stopped by ice on the roads": New Zealand Television Archive).

H77. 'Arrowtown.' The South Tonight 15 Dec. 1978 ("Barry Crump is involved in a scheme to set up a replica of a goldmine in Arrowtown's main street": New Zealand Television Archive).

H78. Auckland Star 27 Feb. 1979. Photo of Alan Jervis during filming of "a 13-part series to be named 'Hang on a Minute Mate'... on which the series is based...". Probably the pilot for the series (D2).

H79. ' 'Oil crisis.' Good Day TV1 8 May 1979 (skit by Crump on beating the oil crisis: New Zealand Television Archive).

H80. Good Day TV1 24 May 1979 included "a skit including Barry Crump and an irate neighbour": New Zealand Television Archive.

H81. 'Gold panning.' Good Day TV1 4 Sept. 1979 (humorous interview with Crump at Shotover River: New Zealand Television Archive).

H82. 'Barry Crump returns in film.' Dominion 5 July 1980 ("After a long silence, rugged New Zealand identity Barry Crump ... will make a brief_comeback in a new feature film. The garrulous author ... has a part in John O'Shea's film 'Pictures' ...": see F2).

H83. 'Crump tales for series.' Auckland Star 31 July 1980 (Hang on a Minute Mate stories "to be made into a television comedy series ... a Christchurch production company, with financial backing from the BCNZ's Committee for Independent Productions, plans to start shooting the five part series in November/December this year ... a pilot was made last year"; this is D2 above, but the article adds of the producer and director Alan Lindsay that he "directed a film based on the same stories about six years ago").

H84. Graeme Kennedy. 'The good keen man's back.' Auckland Star 4 Oct. 1980. Interview. "New Zealand's original good keen man ... has emerged from seven long years of seclusion — with a deep Rarotongan suntan and his first book for

Kōtare 4, no. 2 (2001), pp. 3-160. 
Interview. "New Zealand's original good keen man ... has emerged from seven long years of seclusion - with a deep Rarotongan suntan and his first book for nearly a decade ... will publish Shorty himself although, he says, publishers are almost queuing up to get their hands on the manuscript '...I suppose my personal attitudes to life have changed since I gave it all away seven years ago......quite suddenly ... I got sick of the scene ... there was no challenge left... Baha'i seemed to have all the answers..."'.

H85. Graeme Kennedy. 'Impossible! Not to those two good, keen Crumps.' 8 O'Clock 1 Nov. 1980 (on printing and distribution of Shorty: T really didn't know what I was letting myself in for...').

H86. 'Author in comeback.' NZ Herald 11 Nov. 1980: 11 ("Out of retirement"; Shorty to be published; rehearsals under way for television series based on Hang on a Minute Mate).

H87. Amanda Samuel. 'Barry has a new book (and a new view of women).' NZ Woman's Weekly 8 Dec. 1980: 64-5, 67 (photos by Derry McLachlan of Crump, Crump and Robyn, Crump and Ric Welland) ("... 'I've superficially changed the way I live', said Barry, when asked what differences becoming a Baha'i had brought to him, 'I was pretty careless morally beforehand. I was prejudiced about women, now I'm more realistic...'; ... [Robyn] had never read his books and now that she has tried, doesn't like them. 'They're just not my sense of humour...'. It is Barry's freewheeling lifestyle that appeals to Robyn..."; writing and publication of Shorty (see B15); filming of Hang on a Minute Mate: see D2).

H88. John Thomson. New Zealand Literature to 1977, A Guide to Information Sources. Detroit: Gale Research Company, 1980 (American Literature, English Literature, and World Literatures in English vol. 30; Gale Information Guide Library; 0810312468). x,272pp. Reference to A Good Keen Man p.204 ("heightened yarns").

H89. Phil Gifford. 'Crump moves on.' Listener 21 Feb. 1981:107-8 (photo of Crump by Bruce Connew). Interview: Returns to writing with Shorty; '"I was quite pleased to have a rest from writing. I'd had a gutsfull of all the argy bargy and baloney that goes with it' ...People who knew the old Crump ... remember a part of his personality the jovial public face never revealed. 'There was a ruthless side...'. Crump himself is puzzled that his early books are moral in a way that didn't accurately reflect the man he was at the time. T used to be quite a foulmouthed guy but I never put any foul language in any of the books. And it's the same with sex...' He does have enough fondness for his work to firmly deny suggestions that many of his stories are old bush folklore rewritten to suit his purposes ..."; language of Shorty (see on B15); script of television film Hang on a Minute Mate (see on $\underline{\mathrm{D} 2}$ ) ...

H90. Graeme Kennedy. 'Barry's new book is a load of old rubbish.' Auckland Star 4

Kōtare 4, no. 2 (2001), pp. 3-160. 
... the big-sellers of the '60s I became too big in the public eye for what I really wanted ... that wasn't me ... I never tried to make a living at writing ... Now, I really want to get into it — just make enough to keep us going...'; Puha Road to be published later this month ... about two guys who start a rubbish dump in Heme Bay..."').

H91. 'Crump rolls into Pacific' Auckland Star 12 Aug. 1981 ("Author, bushman and raconteur Barry Crump arrived at work yesterday to start his new job in a hired Rolls Royce. He will host the first programme to go on air when revamped Radio Pacific gets underway at 6 a.m. next Monday. 'We're gonna call it The Crump Hour... it ought to be a bit of fun. If it isn't it's not worth doing, is it?'...")

H92. NZ Woman's Weekly 7 Sept. 1981: 45: brief note in 'Scene and Heard' column (with photo) announcing 'The Crump Hour' on Radio Pacific, Auckland, 6am7am ("promises less talk, more fun, and has co-opted his faithful dog Scum as Number One offsider").

H93. Nick Hill. 'Contented Crump a comeback.' Television News NZ Herald 15 Sept. 1981: 16 (Crump working Radio Pacific, living in a flat in Auckland; wrote a couple of television plays, offered "pathetic money"; says he "does not care a fig if his books do not sell").

H94. 'Gold.' 7:30 South 6 Oct. 1981 (Crump included in this programme on "the recreational goldminer and the large companies in Otago": New Zealand Television Archive).

H95. James Burns. New Zealand Novels and Novelists 1861-1979, An Annotated Bibliography. Auckland: Heinemann, 1981. 0868633720. 71pp. Lists Crump's work to date with brief annotations.

H96. Denis Glover. Hot Water Sailor 1912-1962 \& Landlubber Ho! 1963-1980. Auckland: Collins, 1981. 0002169851. 247pp. Crump pp.231-2: account of a visit from a wet Crump and ladyfriend - "Good old Barry was so confidently self-assured that people, a lot of them women, thought that he must always be right. He was often disastrously wrong, only too willing cheerfully to admit it."

H97. C.K. Stead. In The Glass Cage, Essays on Nezv Zealand Writing. Auckland: Auckland University Press; Oxford University Press, 1981. 0196479959. 293pp. Crump p.113 (reprint of introduction to Maurice Duggan's Collected Stories; H27); p.270 in 'A poet's view' (Winter lectures, University of Auckland, 1974), referring to Shadbolt's lecture and his comment that New Zealand fiction writers can now live by writing: "I know of only two who have lived for any significant period of their lives by writing fiction and they are Barry Crump and Ngaio Marsh". 
Marsh".

H98. Nelson Wattie. 'New Zealand' in Jiirgen Schafer, ed. Commonwealth-Literatur. Dusseldorf: August Bagel Verlag; Bern und Miinchen: Francke Verlag, 1981. (Studienreihe Englisch Band 43; 351302293X; 3772012825). 244pp. Brief mention of Crump p.72: "In unseren Tagen wird diese Tradition [sc. of Frank Anthony] von Barry Crump weitergefuhrt".

H99. '... etc; a weekly column of people and events' NZ Listener 17 April 1982: 136 (note on Crump: reprinting A Good Keen Man and Bastards; on Radio Pacific; "says he is more in touch with people than he's ever been in_his life and that there might still be another book inside him somewhere").

H100. '3-in-l Crump movie.' Auckland Star 4 Nov. 1982 (preview of television showing of 'Hang on a Minute Mate' (D2) with details of its distribution on video in New Zealand and overseas).

H101. Tony Reid. 'Crump flags it away.' NZ Listener 20 Nov. 1982: 22-3, 25 (interview: "Goodbye talkback ... going bush again"; his life, religion... prelude to television showing of 'Hang on a Minute Mate'; D2).

H102. 'Sam Cash hangs on to TV Two.' Evening Post 22 Nov. 1982 (preview of 'Hang on a Minute Mate', "tonight on Two at 8"; D2).

H103. Dave Andrews. 'Crump steals it.' TV Today, Auckland Star 8 July 1983 ("Good keen man Barry Crump stole the show for New Zealand at the FACTS television advertising awards in Australia. His Toyota commercial ... scooped two big prizes...").

H104. Dec. 1983 interview in Auckland (quoted Hogg Loose Strides p. 160).

H105. Joseph and Johanna Jones. New Zealand Fiction. Boston: Twayne Publishers, 1983. (Twayne's World Author Series TWAS 643; 0805763686). [xx],114pp. Crump p.60 ("has carried the New Zealand flag for a type of rowdy picaresque humor endemic in a few writers from Mailing's Old New Zealand in the 1860s...") and p.67 (in list of humorous writers).

H106. Dennis McEldowney. Full of the Wild South. Dunedin: John Mclndoe, 1983. 0868680567. 208pp. Crump p.40: "20 [November 1963] Tuesday. Maurice [Shadbolt] will read in a report of his talk in the Otago Daily Times that his writing has been influenced by Barry Crump and George Wilder. What he did say is that he regards both as hopeful signs, showing that New Zealanders have not lost the capacity to create genuine folk heroes.".

H107. 'Spare me days Scottie, it's a Silver Lion.' NZ Herald 11 Oct. 1984: 3 (Silver Lion award to Colenso for Toyota ad.; quotes Lloyd Scott: "Actually, Barry's

Kōtare 4, no. 2 (2001), pp. 3-160. 
H108. 'The frugal life of Barry Crump.' Dominion 24 Oct. 1984 (with photo):_Crump and Robyn living at Collingwood; 'People don't believe our lack of interest in material possessions...'; Crump disagrees that the [Toyota] advertisement could encourage reckless driving; 'I've been writing some good stuff lately — some far out poetry. I've written a really beaut novel about two blokes and how long they can hold out in Urewera National Park'. He had hundreds of requests for 'a bit of madness' - a poem which was read out on Radio Pacific [B17]; 'I'm probably one of the best men I have met. I'm honest and straight and I have to be discreet about how I handle things and people for that reason'".

(Same material, with variations, in: "'A hell of a seeker" — Baha'i Crump is committed and writing' Evening Post 24 Oct. 1984; 'Barry Crump still keen man — on Baha'i' Hawkes Bay Herald Tribune 24 Oct. 1984; 'Barry Crump now a keen Baha'i' NZ Herald 29 Oct. 1984:14; 'Barry Crump now keen and good' The Press 25 Oct. 1984:19).

H109. Gordon McLauchlan, ed. Bateman Nezv Zealand Encyclopedia. Auckland: David Bateman Ltd, 1984. Article on Crump (" ... became a cult-figure in the 1960s as a symbol of the self-reliant Country Man ..."); 2nd ed. 1987 (repr. 1990); 3rd ed. 1992; 4th ed. 1995; 5th ed. (editor Lynne Richardson) 2000 (expanded article).

H110. Hamish Keith. New Zealand Yesterdays: A Look at Our Recent Past. Text by Hamish Keith; Picture Research by William Main. [Sydney]: Reader's Digest Services, 1984. 0949819832. 320pp.; revised edition ("First edition, first revise") (c 1985. P.110: "'Humping the bluey' in search of work or freedom, carrying swag. Perhaps the swagger was not far from Richard Seddon's mind when he wrote in the Liberal manifesto in 1904: 'A spirit of self-respecting independence already marks our people and I would have the title 'New Zealander' imply ... a type of manhood, strenuous, independent and humane'... Seddon's stereotype reappeared in the 1960's in the 'good keen man' fashioned by ... Barry Crump".

Hill. Lloyd Jones. 'The world of advertising according to Len Potts.' Wellington City Magazine Aug. 1985: 24-8 (interview with maker of the Toyota ads; references to Crump).

H112. Harry Crump. 'My famous Dad.' Wellington City Magazine Aug. 1985: 69 ("I never knew him well ... I learned about him by reading the newspapers"; works as a gardener "and I write a lot".)

H113. 'Grizz's car.' The Mainland Touch 25 Sept. 1985 ("skit involving 'Scotty' ... and Barry Crump attempting to repossess Alex Wylie's Toyota car": New Zealand Television Archive).

H114. Don Grady. 'Crump's into nanny business.' Weekend Star 28 Sept. 1985: 4 (Crump and Robyn goat farming on their Bay of Plenty property; this week

Kōtare 4, no. 2 (2001), pp. 3-160. 
H114. Don Grady. 'Crump's into nanny business.' Weekend Star 28 Sept. 1985: 4 (Crump and Robyn goat farming on their Bay of Plenty property; this week Crump and Scotty in Christchurch to assure Canterbury rugby coach Alex Wylie that Grizz could keep his red and black Toyota...).

H115. Crump interviewed on radio by Jessica Waddell about his life and work, 19 Oct. 1985, 30 min. (Radio NZ Sound Archive).

H116. 'Barry lays it out on gst videotape.' Evening Post Arts, Music, Theatre, 8 Nov. 1985 (account of the video explaining GST starring Crump and Peter Bland. "Gst launch co-ordinator Mr Geoff Todd ... again rejected suggestions that the publicity campaign for gst was straying into the political arena and actually promoting the tax..."; see $\underline{\mathrm{F} 3}$ ).

H117. 'Christmas presents. Little things can mean a lot' NZ Woman's Weekly 2 Dec 1985: 12-13: Crump one of those asked what they will be giving for Christmas: "Barry Crump is not one to celebrate Christmas, though he does believe in Christ. Barry does give gifts, it's just that he doesn't wait for a special reason to do so...".

H118. Bill Lennox. Film and Fiction, Studies of New Zealand Fiction and Film Adaptations. Auckland: Longman Paul, 1985. 0582857104. xv,152pp. Pp.1-16 on film 'Lawful excuse' (1ㅡ).

H119. Profile of Crump on Gordon McLauchlan's Weekend, TV1 29 Jan. 1986 (New Zealand Television Archive).

H120. Kate Coughlan. 'Author still in shadow of "A Good Keen Man".' New Zealand Times 6 April 1986; 29.

H121. 'Golden Kiwi Comedy.' TV1 15 April 1986 (Crump included in this "compilation of comedy clips ... portraying the last 30 years of New Zealand television comedy": New Zealand Television Archive).

H122. 'Swanndri.' Country Calendar TV1 4 May 1986 (Crump in "a light-hearted look at the origins of Swanndri clothing": New Zealand Television Archive).

H123. Jane Westaway. 'Greymouth will never be the same again.' NZ Woman's Weekly 19 May 1986:18-19: Crump ("a mythological figure") in celebrity debate with Tim Shadbolt, Keri Hulme, The Wizard and others; Crump quoted.

H124. Crump on Sunday TV1 29 June 1986 (later included in The Way We Were series; New Zealand Television Archive).

H125. Jane Westaway. 'Barry Crump: portrait of a happy man.' NZ Woman's Weekly 14 July 1986:12-13 (with photos). Interview (" ... [my books] used to be a bit

Kōtare 4, no. 2 (2001), pp. 3-160. 
make a craft of it now").

H126. Graham Scott. 'Good keen bid to lick challenge.' NZ Herald 4 Aug. 1986: 20 ("...the bushman-author is on the comeback trail in a big way..."; Wild Pork "Crumpy's most serious book yet ... he has rewritten the beginning three or four times and polished and constantly reworked other passages...").

H127. 'Novelist satisfied.' NZ Herald 17 Sept. 1986 ("...has just finished Wild Pork and Watercress - the only thing he had ever written he liked better than $A$ Good Keen Man...").

H128. A number of newspaper articles previewed the launch of Wild Pork and Watercress:

Graham Scott. 'Book bash dash into bush.' NZ Herald 9 Oct. 1986: 1; 'Book launch will be rugged affair, befitting author.' Evening Post 10 Oct. 1986 ("setting is to be rugged bush, near a tumbling river ... the author ... plans to fly in by helicopter, carrying a wild pig..."); 'Crump goes bush for launching.' Press 10 Oct. 1986; 'Crump book launching in wilderness.' Marlborough Express 10 Oct. 1986.

H129. The launch itself was widely covered:

Graham Scott. 'Good keen 200 in Crumpdom.' NZ Herald 15 Nov. 1986: 1 (photo of Crump with Captain Cooker on his shoulder).

Paul Dyer. 'Me cobber's overwhelmed.' Daily Post 15 Nov. 1986 (on young "Lyle Matu" at the launch).

Jill Nicholas. 'Barry's big day had 'em all bushed!' Sunday News 16 Nov. 1986: 5 (photos of "Barry's young mate, Lyal [sic] Matu" and Robyn; quotes from father Wally Crump).

Tony Potter. 'Good keen bash in the back of beyond.' Sunday Star 16 Nov. 1986 (quotes a letter from Sam Hunt "who wrote to the Sunday Star raving about the ... excerpts we carried last week...").

Cindy Bowater. 'Day out with Crumpy in Urewera kingdom' Whakatane Beacon 18 Nov. 1986.

Top Half (Auckland local news programme) TV1 18 Nov. 1986 ("Norris Power reports on the launch...": New Zealand Television Archive).

'Wild pork, watercress help novel book launch.' Bay of Plenty Times 19 Nov. 1986. 
H130. Katie Sims. 'A good keen woman.' NZ Herald 27 Dec. 1986 (interview with Robyn - "...I'm a hard person to get on with ... I'm very forthright... Barry and I get on really well and we like doing the same sort of things...").

H131. Barry Crump interviewed by George Balani, Radio New Zealand Commercial Network, Tonight Show, 9 Dec 1986; 60 min. (Held by Radio NZ Sound Archive).

H132. Philip Tew. Writers of New Zealand Fiction. Christchurch: Language \& Literature Dept, Canterbury Public Library, 1986. [ii],44pp A4 wrappers. Crump p.9 ("...The later novels aren't as good nor have they been as popular as the earlier ones. The possible reason for this is that we've become a more urban society or our perception of ourselves has been more urban and these stories belong to simpler times").

H133. Jean Watson. Address to a King. Wellington: Allen \& Unwin / Port Nicholson Press, 1986 (0868615943). 73pp. Crump apparently at least partly the basis for the character Erin ("...When Erin and I were young ... we travelled up the northeast coast of Australia in our boat..."); see John O'Shea, Don't Let It Get You (는 $)$; quoted in H34.

H134. NZ Sunday Times Jan. 1987. Interview, quoted Hogg Loose Strides pp.170-2.

H135. Mervyn Cull. 'Crump's new tail.' Books and Writers column NZ Herald 26 Feb. 1987 (with photo; "Wild Pork and Watercress has sold 36,000 copies since publication in November last year ... he is about 12,000 words into another book, which is set in Otago and is basically about a man's relationship with his dog. The working title is Barney's Dog ..." [Bullock Creek]).

H136. 'Yanks eye Crump.' Sunday News 15 March 1987 (interviewed on Lifestyles of the Rich and Famous - "They mainly asked me how I lived and what I did, and about my writing and television acting...").

H137. Iain Sharp. 'Barry Crump, A good keen man from the eighties.' NZ Outlook 2 (April 1987): 48-53 (photos by Sally Tagg). Interview: Wild Pork already reprinted twice; pressures of fame; "no New Zealand writers he especially admires — 'not good enough ... copying English tradition ... too selfconscious'"; Kevin Ireland, Jean Watson, Fleur Adcock.

H138. Nina De Their. 'Good keen Kiwis.' Pacific Way April-May 1987: 30-33: interviews Crump and Billy T. James ("Crump has tended to write from experience but he insists fiction is well-woven into his stories ... There's no use planning anything ... I just live in the now and occasionally I write a book").

H139. That's Fairly Interesting TV2 21 May 1987 ("Stories about people that are weird and wonderful. Tonight Barry Crump is run to ground in his East Coast

Kōtare 4, no. 2 (2001), pp. 3-160. 
hideaway...": New Zealand Television Archive; Crump also in 4 June and 11 June 1987 programmes).

H140. W.H. New. Dreams of Speech and Violence, The Art of the Short Story in Canada and New Zealand. Toronto: University of Toronto Press, 1987. 0802056636. xi,302pp.: Crump pp.150-1 ("...many of Davin's stories ... proved to be ... narrative jokes that make him a transition between Frank Anthony's Me and Gus and Barry Crump's Warm Beer and Other Stories..."); p.164 (quoting Maurice Duggan's "a genuine crumpy conversation" and C.K. Stead's commentary); p.167 ("...Barry Crump was continuing to pen anecdotes of the inarticulate male").

H141. Jock Phillips. A Man's Country? The Image of the Pakeha Male - A _ History. Auckland: Penguin, 1987. 0140093346. ix,321pp.; revised edition Auckland: Penguin, 1996. 014025658X. ix,321pp. Crump pp.266,288 ("...People laughed at Crump's men but always with a secret admiration. They were 'a bit of a dag', to be respected for their 'hardness' ..."). Review article on first edition: Keith Johnston. 'A history of manly ways.' Dominion Sunday Times 2 Aug. 1987 2: 17 (with photo of Crump) ("...The civilising struggle lasted a century, till the 1950s. Then, as society became more urbanised, the larrikins became more entertaining than threatening Barry Crump's good keen men, John Mulgan's Man Alone, and prison-escaper George Wilder, all enjoyed bursts of popularity in the early 1960s...").

H142. Crump featured in TVNZ Network News report 20 Nov. 1988 on donkeys pulling a carriage round Queenstown (New Zealand Television Archive).

H143. Warren Barton. 'Keepin' the peace.' Dominion Sunday Times 10 Jan 1988: 9 (photos by Don Roy). Interview (early life; travelling; Baha'i; Robyn; "... If we were ever broke I'd write a book, publish 5000,10,000 copies and sell them just around Auckland... At one stage I was whacking 'em out like a weight of throbbing spaghetti on a plate..."; possum trapping; working on a book "about a man and a dog ... I'm really getting into writing proper novels and it's quite a craft. As you get older you lose the vigour of the writing of your youth but you gain the craft... And you know, there's only one story. Everybody's only got one yarn really but you can put so many slants and angles on it...").

H144. Ian Cross. The Unlikely Bureaucrat, My Years in Broadcasting. Wellington: Allen \& Unwin / Port Nicholson Press, 1988 (0868615552). [viii],242pp. Pp.1920 on rejection of Crump as reader on radio of A Good Keen Matt -"...hired a professional actor who simulated a vague New Zealand accent within what were deemed to be proper limits. A Good Keen Man was nevertheless a successful programme, it greatly stimulated interest in the book and in the author as a personality. Radio now actually conducted a long interview with him, and his voice and manner before a microphone caused a favourable audience reaction" (see also $\underline{\mathrm{H} 310}$ ).

Kōtare 4, no. 2 (2001), pp. 3-160. 
H145. Ian Johnstone. Stand and Deliver. Whatamongo Bay: Cape Catley Ltd, 1988. 0908561709. vii,244pp. ("recollections of episodes, people and pro-_grammes ... after working in television over the last thirty-five years"; p.41 brief note on interviewing Crump on Close Up soon after publication of Hang on a Minute Mate - "... Was he interested in other arts — painting, for example? 'Aw no, not really — but I once gave a mate a hand to paint his roof."'; $\underline{H 17})$.

H146. David McGill. Up the Boohai Shooting Pukakas, A Dictionary of Kiwi Slang. Lower Hurt: Mills Publications, 1988. 0908722354. 128pp. P.6: "...a number of writers and compilers were goldmines of informal language, notably F.S. Anthony ... Barry Crump, particularly for Hang on a Minute Mate ..." (see also $\underline{\text { H275). }}$.

H147. Toni McRae. 'Croc Dundee "with New Zealand accent".' Auckland Star 15 Feb. 1989: A 1 (interview; "...a voice resembling a bassoon with a cold...").

H148. Item deleted.

H149. Accounts of launching of Bullock Creek:

Top Half (Auckland local television) 26 July 1989.

Suzanne Kemp. 'Crump still a good keen man.' The Press 27 July 1989: 5.

Barbara Webb. 'Up Bullock Creek on the Elephant.' Evening Post 29 July 1989 (launch of Bullock Creek in Opotiki backblocks, Elephant beer, what makes Crump 'a real Kiwi Joker'?).

Keith Cronshaw. 'The original "good keen man".' Christchurch Star 5 Aug. 1989: 5 (long account of the launch).

TV2 Wellington local news 31 July 1989.

H150. Phil Pennington. 'Crumpy's just cruisin'.' Sunday News 1 Oct. 1989 ("Nothing's fair. It's just what you get away with that counts" says Crump comparing his withdrawn Toyota ad and one for Eta chips; latest round of ads will be "more hair-raising than anything we did in Wellington".)

H151. Stephen Barnett, ed. Those Were the Days: A Nostalgic Look at the 1960s from the Pages of the Weekly News. Auckland: Moa Publications, 1989 (1869470486). 175pp. Photos of Crump p.16 (1960) and p.70 (Crump and Fleur Adcock in Land Rover, 1962; $\underline{\text { H20 }}$ ).

H152. Jim Henderson. Jim Henderson's New Zealand. Wellington: Grantham House, 1989. 1869340205. viii,135pp. Brief reference p.130 to his replacing Crump on Radio Pacific talkback: "I succeeded the long-cherished no-nonsense Barry

Kōtare 4, no. 2 (2001), pp. 3-160. 
Crump".

H153. Kevin Ireland. The New Zealand Connection, A Celebration of the New Zealand Novel. Auckland: Random House, 1989 (1869540077 cased; 1869540034 limp). 223pp. "An enthusiast's introduction to the rewards of the New Zealand novel... 52 of our best novels ... an extract from the plot, a synopsis of the plot, and a biographical note on the author ... [with] reproductions ... of works by wellknown New Zealand artists..." (dust-jacket flap). Crump pp.67-9: extract from Hang on a Minute Mate (pp. 144-5) with 2 page commentary (".. .sometimes misrepresented as a collection of short stories ... actually a novel written in seventeen linked episodes of forward narrative interwoven with reminiscence ... one of the few competently structured picaresque novels in New Zealand literature..."

Review: David Hill, Dominion Sunday Times Dec. 3 1989:19 ("... I'll commend some stimulating choices ... Hang on a Minute Mate (that vastly underrated book), not A Good Keen Man...").

H154. Gordon McLauchlan, ed. The Illustrated Encyclopedia of New Zealand. Auckland: David Bateman, 1989 (@1986). 1869530071. 1448pp. ("Originally published in 52 parts by Windsor Watt Ltd., Auckland (C) 1981" — unseen): Crump p.272 (similar article to that in Bateman New Zealand Encyclopedia (1984; $\underline{\text { H109)}), ~ w i t h ~ p h o t o) ; ~ r e f e r e n c e ~ t o ~ C r u m p ~ u n d e r ~ ' L i t e r a t u r e ' ~ p p .696-7 . ~}$

H155. 'What Next' Wild South TV1 14 April 1990: Crump featured in programme on "Australian immigrants to New Zealand, birds and seeds which make it across the Tasman..." (New Zealand Television Archive).

H156. 'Crump's new book an autobiography.' Sunday Star 22 July 1990 (with photo; ".. .has been quietly penning his autobiography for two months ... this is the book, in a sense, he has always written, yet always wanted to write. 'A Strand of Rope, I'm calling it' ...; has just been previewing a new documentary made about him ... 'It's great mate ... You've got to see it'...").

H157. Magic Kiwis (series 2, programme 2) television documentary on Crump made by Communicado, shown TV1 3 Aug. 1990; writer, director John_Harris; producer Roger Price; fronted by Neil Roberts. This was released on video: Magic Kiwis. Crump. Communicado; [Lower Hurt]: Television New Zealand, [1990]. 1 videocassette (23 min.). (Hogg Loose Strides pp.181-2). Published as a book in 1991 (ㅌ165).

Previews of the documentary: Dominion Sunday Times (August?) 1990 (quoted by Hogg Loose Strides p.181); 'Books made storyteller of good, keen man' NZ Herald 3 Aug. 1990:15.

H158. Sunday \{Dominion Sunday Times magazine) 19 Aug. 1990: 26 (photo of Crump with dog and ute). Interview with Crump in 'Favourites' section on his favourite

Kōtare 4, no. 2 (2001), pp. 3-160. 
Films, Shows, Books ("clues to the Listener crossword"), Music, Places ("New Zealand"), Pastimes, People ("the Tibetans").

H159. Patrick Evans. The Penguin History of New Zealand Literature. Auckland: Penguin Books (NZ) Ltd, 1990. 0140113711. 287pp. Crump p.199 ("...Crump wrote too much ... but his fiction represents one possible way out of the limitations of the provincial novel").

H160. Keith Sinclair, ed. The Oxford Illustrated History of New Zealand. Auckland: Oxford University Press, 1990. 0195582098. viii,389pp.; (reprinted 1993; new edition, 1996; 0195583388. One sentence on Crump p.95 in Barry Gustafson's chapter 'The National Government and Social Change (1949-1974)': "Barry Crump's popular books ... written in an anecdotal style and New Zealand idiom".

H161. Geoff Chappie. 'They did it.' Sunday Star 28 July 1991; C 1. Article on selfpublishing in New Zealand, Crump among those quoted (his self-publishing successful, but "... [by the mid 1960's] I was having trouble extracting money from booksellers...", teamed up with Craig Howan; Crump receives "close to $20 \%$ of the retail price...").

H162. Terry Sturm, ed. The Oxford History of New Zealand Literature in English. Auckland: Oxford University Press, 1991 (019558211X cased; 0195582403 limp). xviii,748pp. Crump: p.235 (Lydia Wevers on 'The Short Story': "invention became stereotype, and complex ambiguity turned into iconic platitude"); p.497 (Terry Sturm on 'Popular Fiction': "a rare instance of a bestselling New Zealand author who has remained largely unpublished outside this country"), pp.528, 530-1 ("The basic formula ... is relatively simple, though not the professional skill with which he continued to work towards producing variations of it"); p.580 (Dennis McEldowney on 'Publishing, Patronage, Literary Magazines': "[Reeds as publishers] plugged into the national psyche ... [A Good Keen Man] almost a caricature of the genre"); p.587 ("the egalitarian mateship connotations of the title [of the periodical Mate] seemed to be confirmed by the discovery of Barry Crump"); p.651 (Bibliography by John Thomson).

H163. 2nd edition, Auckland: Oxford University Press, 1998. 019558385X. xxi,890pp. Above references now pp.275, 379, 608, 609-10, 620 (new paragraph on 1990s Crump titles — "remained a master of the tricks-of-the-trade of the raconteur ... the 'real' New Zealand for which he stood ... always a carefully crafted and sustained masculinist invention"); 626 (brief note, "Crump's masculinist celebrations of the outback"); 664; 670; 794 (extended bibliography).

H164. Rob Taylor. 'Dennis Knight Turner — Artist' in John E. Martin and Kerry Taylor, ed. Culture and the Labour Movement, Essays in New Zealand Labour History. Palmerston North: The Dunmore Press, 1991. 0864691599. 316pp. Pp.197-208 (p.204: "...the obvious choice to illustrate Barry Crump's first four 
books. Turner's down to earth approach is entirely appropriate for describing the characters and events from Crump's yarn-spinning while visualizing intensely concentrated graphic encapsulations of that society and area...").

H165. Bryan Staff. Magic Kiwis: A Celebration of the New Zealand Achievement. Auckland: Moa Publications in association with TVNZ Enterprises, 1991 (1869470826). 208pp.. ("Companion to ... [the] television series" (1157); on dust-jacket: "New Zealand's most notable achievers"). 'Barry Crump, One strand of the rope' pp.[52]-63 (with 8 photos): interview: "The night before Barry Crump turned 55, the Magic Kiwis crew joined him for a fireside chat..." — reminisces about Town and Around programmes, his Media persona character switched on when cameras roll — 'I'm doing it now — rough, tough, very funny, and about as thick as pigshit!'; "scenes from a home made movie in the early fifties by Canadian deer hunter Ron Helmer show Barry looking much like a young Bob Dylan...".

H166. Geoff Chappie. 'Crump hits city for launch of new book.' Lit-Synch_column Sunday Star 5 July 1992 ("...45,000 cartoned copies of his self-published Life and Times of a Good Keen Man, just arrived from his Australian printer, and due to go on sale July 8 . That's a lot of books, but 15,000 of them are pre-sold... 'I'm not afraid of literary-or-however-you-pronounce-it judgements. Because I think I've got a toehold on the people."').

H167. Holmes TV1 7 July 1992: "Paul Holmes visits Barry Crump in a warehouse where the copies of his autobiography ... just released, are stored" (New Zealand Television Archive).

H168. Jack Leigh. 'From the pen of a good keen man.' NZ Herald 18 July 1992 2: 6. Profile of Crump and his books, reviewing The Life and Times of a Good Keen Man.

H169. Sarah Stuart. 'Hobo with a credit card.' NZ Woman's Weekly 10 Aug. 1992: 86. Profile of Crump.

H170. Stacy Gregg. 'Barry Crump is New Zealand's version of Crocodile Dundee - a man who's done it all.' Pacific Way. 55 (Sept. 1992): 16. Profile of Crump, reviewing The Life and Times of a Good Keen Man ("likes a life where everything he owns can be carried or at least fit on the back of his Ute").

H171. 'Here is the News' shown TV1 3 Nov. 1992: Crump included in this "nostalgic look at New Zealand news covered on television in the past three decades" (New Zealand Television Archive).

H172. The Oxford English Dictionary, Second Edition, on Compact Disc. Oxford: Oxford University Press, 1992. This includes 76 citations from Crump (Hang on a Minute Mate, A Good Keen Man, and stories in NZ Listener and NZ 
Weekly News) illustrating words such as 'crook', 'bitching', 'have a bo-beep', 'made a blue', 'go on the bash', 'Dally', 'gut-shoot', 'gutser', 'herd-tester', etc. Crump citations were first included in Volume 1 of R.W. Burchfield, ed. A Supplement to the Oxford English Dictionary. Oxford: Clarendon Press, 1972 (vols. 2-4,1976,1982,1986; Compact Edition 1987).

H173. Jill Herron. 'Crump far from materialistic' Otago Daily Times 10 May 1993: 9. Interview with Crump about his lifestyle and writing.

H174. Colin Hogg. 'Sky high. The usual stuff.' Southern Skies July 1993: 64 (brief Crump quote).

H175. Colin Hogg. 'Wandering star.' Southern Skies Aug. 1993:10-12,14,16-18, 20 (and cover photo). Interview with Crump about his life and books. Reprinted with alterations in Tribute.

H176. 5.30 Live. TV3 23 Sept. 1993: "Clip from Living Earth with Barry Crump"; reporter Annie Whittle.

H177. Announcement of award of M.B.E.:

'"Nice to be recognised as a damn good bloke".' Dominion 31 Dec. 1993 ("Archetypal hard case Barry Crump dismisses any suggestion that being made a member of the Order of the British Empire signals a move to join the Establishment. 'I am the Establishment, mate ... The Bushman Establishment..."'); NZ Herald 31 Dec. 1993: 4; Network News (TVNZ) 31 Dec. 1993.

H178. Maggie Crump. 'A good keen woman: life with Barry.' North and South Feb. 1994: 90-6 (chatty account of meeting Crump, typing book, marriage, life in Wanaka ...).

H179. Holmes TV1 24 March 1994. Interview with Crump (living near Cardrona, with Maggie; tells how years ago he got home, found wife had bought Whiteway washing machine with ringer, went to front gate, kept on going...).

H180. Barry Clarke. 'Crump in court.' Sunday Star Times 17 April 1994 ("The good, keen man Barry Crump will appear in court this week charged with resisting police...").

H181. Jason Barber. 'Gong for a good keen writer.' NZ Herald 21 May 1994 (photo of Crump after M.B.E. investiture; "...I'll stick it in a drawer...").

H182. 'Crump remand.' Evening Post 22 May 1994 (remanded to August 31).

H183. Tony Potter. 'The changing face of New Zealand.' Sunday Star Times 19 June

Kōtare 4, no. 2 (2001), pp. 3-160. 
1994 C 1-2 (".. .your typical Kiwi Good Keen Bloke ... a myth ... New Zealand is overwhelmingly urban ... The good Kiwi bloke — we've been sold_that. Every time Barry Crump does something he's a hero. It's got nothing to do with reality...").

H184. 'Crump acquitted of driving charges.' TV3 News 20 Oct. 1994.

H185. 'Barry Crump cleared of charges.' Dominion 21 Oct. 1994 (charged with refusing to allow a blood sample to be taken and resisting arrest; charges dismissed because of procedural breaches).

H186. Open Home TV1 25 Nov. 1994 (Crump included in this "programme about New Zealand homes": New Zealand Television Archive).

H187. Terry Sturm. 'Barry Crump' in Eugene Benson and L.W. Connolly, ed. Encyclopedia of Post-colonial Literatures in English. 2 vols. London and New York: Routledge, 1994. Vol.1 pp.314-5 ("... celebrates the New Zealand male icon of the Man Alone ... avoiding any lasting social ties such as mateship or marriage. Its roots lie deep in the popular journalism pf pioneering days that became the subject of more serious fictional treatment in the work of Frank Anthony, John Mulgan, Frank Sargeson and others. In Crump's contemporary male populist novels, however, the moral or social implications of the Man Alone icon are rarely questioned").

H188. Elizabeth and Harry Orsman. The Nezv Zealand Dictionary. Standard Edition. Auckland: New House Publishers, 1994. 1869460170. xv,321pp. "A selection of words and phrases which are in some way distinctively, but not necessarily exclusively, part of the spoken or written language of English-speaking New Zealanders" - Preface; "the first comprehensive dictionary of New Zealand English" - dust-jacket flap. Crump cited as source of several expressions, e.g. 'Take to one's scrapers'.

H189. Gordon Ell. New Zealand Traditions \& Folklore. Auckland: The Bush Press of Auckland, 1994. 0908608675. 239pp. The entries (which are in alphabetical order) include 'A Good Keen Man' and 'Hang on a Minute Mate', with a reference to the phrase "hang on a minute mate" under 'Taihoa' and a quote from Crump ("a man needs a shed") under 'Backyard Sheds'.

H190. Allan Farmer, with Jim Graydon. The Best Job Ever (A Life of Hunting). Auckland: Halcyon Press, 1994. 0908685777. 272pp. Hunting with Crump p.110, photo p.83 and pp.183-5 reprint a humorous 1960 letter from Crump discouraging him from marrying.

H191. Nick Perry. Toyota country and Toyota city: urbanism and New Zealand popular culture.' Culture and Policy 6,1 (1994); also available online at $<$ http://www.gu.edu.au/centre/cmp/6_1_06.html> (viewed 27.9.01); a longer

Kōtare 4, no. 2 (2001), pp. 3-160. 
version of this paper appears as chapter three of his The Dominion of Signs: Television, Advertising and other New Zealand Fictions. Auckland: Auckland University Press, 1994: Sociological comment on the Crump-Scotty Toyota television commercials pp.12, 55-61 (with stills from two of the television commercials pp.57, 61).

H192. Denis Edwards. 'On your marks, Get ready, Write!' Quote Unquote 19 (Jan. 1995): 22-3. Humorous article to decide "the best writer in New Zealand" on the basis of the "Fog Index" deriving from sentence and word length, Crump losing in the final to Vincent O'Sullivan.

H193. 'Good keen man Crumpy takes to the water.' Evening Post 16 Jan. 1995: 14 (with photo of Crump and boat Ocean Star): "...newly settled in Havelock in Marlborough, reckons he can handle a boat as well as a four-wheel drive ... 'A good Kiwi bushman can handle bloody well near anything' ... he will continue working on a new series of children's books about the "ponga people", whom he describes as leprechauns of Maori legend ... Crump's next mission is to find the ponga people ... T live the things I write about. It has to be plausible' ... A Good Keen Man: 'Someone had written a book about deer culling ... but it was mainly about how many were caught. I knew I could write about what it was like, and I did' ... A feature film is being planned, based on his book Wild Pork and Watercress ... suggested ... Lee Tamahori as director...").

H194. Greg Hurrell. 'Good keen bloke sailing the sounds.' Marlborough Express 19 Jan. 1995: 8.

H195. 'Crump in court.' Dominion 26 Jan. 1995: 3: "Author Barry Crump denied in Alexandra District Court on Tuesday charges of driving while disqualified and careless use of a vehicle ... A hearing date was set for March 29." (see also $\underline{\text { H219). }}$.

H196. 'Crump denies driving charges.' Evening Post 26 Jan. 1995: 2.

H197. 'Crump discharged without conviction.' Evening Post 31 March 1995: 14 (judge found "special reasons" for discharge after closed address by Crump's counsel).

H198. Yvonne Martin. 'Crump still Toyota's man.' Sunday Star Times 2 April 1995 (with port.)("...won't stop him fronting the latest TV commercial for Toyota...").

H199. 'Great book debate.' Sunday Star Times 2 April 1995: D 2: Four "literary brokers", Riemke Ensing, Kevin Ireland, Gordon McLauchlan, David Elworthy, asked to chose the 10 best New Zealand books - Crump not chosen, but in 'We choose our top 10 in New Zealand' ("the Sunday Star Times has come up with its own top 10 list. We base it on those books that have a pronounced influence on social change or somehow speak to the national character") A Good Keen Man is included.

Kōtare 4, no. 2 (2001), pp. 3-160. 
Man is included.

H200. Newsnight TV1 7 Aug. 1995 ("...a nightly news and magazine programme. Tonight features Mecca Mix and Mingles and Barry Crump": New Zealand Television Archive).

H201. Newsnight TV1 6 Sept. 1995 ("...Tonight features ... Barry Crump's new book The Pungapeople": New Zealand Television Archive).

H202. Late Edition (TV1 late news) 13 Sept. 1995 ("children's book Mrs Windy flax and the Pungapeople ... launched at Variety Club function tonight": New Zealand Television Archive; brief interview with Crump; met illustrator only at launching; the Pungapeople pixies, leprechauns, elves).

H203. Stamp featuring Crump on sale:

'Large as Life.' Dominion 4 Oct. 1995: 1 "Writer and raconteur Barry Crump poses with a mock-up of the stamp that features him...". Stamps designed by Karen Odiam (later Karen Mounsey-Smith).

H204. Annette Finnegan. 'Post artist makes her own stamp.' Evening Post 4 Oct. 1995: 1 (with photo showing the artist and the stamps): "Post editorial artist Karen Odiam ... designed the Famous New Zealanders stamp issue on_sale today. Dame Kiri Te Kanawa, Dame Whina Cooper, Barry Crump, Sir Brian BarrattBoyes, Sir Richard Hadlee and Charles Upham are the six people voted by New Zealanders to feature on a special New Zealand Post stamp issue. They have all been captured by Miss Odiam in watercolours. It is the first time, the Royal family excepted, that New Zealand stamps have featured living celebrities ... She had no contact with the six, working mostly from photographs and research by NZ Post... Miss Odiam tried to portray the six as people would remember them. ... Her favourite portrait is Barry Crump, because of its colour and the portrayal is a good likeness."

H205. Annette Finnegan. 'Stamping his mark on the world.' Evening Post 10 Oct. 1995: 1 ("Tawa man Peter Bradshaw wants it known that ordinary people have figured on stamp issues besides the famous folk..."; he was on 1938 health stamp, age 2; "...I am just a modern-day Crump without the wrinkles").

H206. 'Sunday Morning with Alison Parr', National Programme, 24 Nov. 1995. Included a one hour talk with four New Zealanders, Lloyd Geering, Moana Maniapoto-Jackson, Margaret Mahy and Crump, on "their childhood memories of Christmas and their feelings and attitudes now". (Copy held in Radio NZ Sound Archive.)

H207. Michael King. Frank Sargeson, A Life. Auckland: Viking (Penguin Books (NZ) Ltd), 1995 (0670838470). 478pp. P.341: Sargeson's first reaction to Crump -

Kōtare 4, no. 2 (2001), pp. 3-160. 
telling...".

H208. Roger Robinson and Nelson Wattie. 'Tapping the rich vein of NZ literature.' Dominion 2 Jan. 1996: 8 "...12 New Zealand books which they think have had the most influence in our country" — includes "A Good Keen Man, Hang on a Minute Mate and others by Barry Crump".

H209. Don Grady. 'Good keen man not so keen on Havelock now.' Marlborough Express 23 April 1996: 1.

H210. 'Flashback.' NZ Listener. 18 May 1996: 10. Reprints the 1962 photo of Crump and Fleur Adcock in the Land Rover ( $\underline{\mathrm{H} 20})$ with caption "Barry Crump and his new wife Fleur - before Toyota got into the picture".

H211. Move to Bay of Plenty:

Dave Blanshard. 'Crump hits Bay hills.' Bay of Plenty Times 25 June 1996: 1. 'Crump and family plan to live in Bay of Plenty.' Waikato Times 26 June 1996: 11. 'Crump shifts to easier digging.' Dominion 26 June 1996: 15 (with photo) ("...The climate is a bit warmer than Wanaka and the digging is easy..."). 'Crump family comes in from the cold.' NZ Herald 26 June 1996: 2. 'Easier digging lures Crumpy.' The Press 26 June 1996:1 ("has moved to rural Bay of Plenty's Welcome Bay ... native tree nursery ... run primarily by Mrs Crump while he works on a new book featuring ... Sam Cash. He was reluctant to talk of progress on the book 'in case my publisher finds out"').

H212. Death announcement and obituaries:

Midday, One Network News, and Tonight TV1 3 July 1996 (New Zealand Television Archive).

Holmes TV1 3 July 1996: tribute to Crump, interviews with Martin Crump and advertising director Len Potts.

'New Zealand author dies of heart attack.' TV3 News 3 July 1996 (report by Karen Pickersgill, and Whena Owen on reactions to his death; shots of Crump reading poem on Living Earth programme).

'Barry Crump dies.' Nightline TV3 3 July 1996 (report by Paul Allen; Craig Howan family spokesperson).

Christine Cessford and NZPA. '"Crumpy" dies of heart attack.' Evening Post 3 July 1996:1 (with photo of Crump taken ten days earlier); quotes Len Potts: "He was exactly as you saw him in real life and on TV".

'Kiwi joker Barry Crump dies. "Unique" Kiwi joker and good keen man Barry Crump dies aged 61.' Waikato Times 3 July 1996: 1.

Kōtare 4, no. 2 (2001), pp. 3-160. 
Crump dies aged 61.' Waikato Times 3 July 1996: 1.

'He's gone, that good keen man. A good keen man gone.' The Press 4 July 1996: 1, 3 (with photo).

'Tributes flow after death of a good keen man.' Dominion 4 July 1996:1 (with photo; quotes tributes from Prime Minister Jim Bolger - "leaves a vacuum in the lexicon of New Zealand characters..." (see $\underline{\text { H221) }}$ — Lloyd Scott, Toyota, Colenso Advertising).

Warren Barton. 'Crumpy calls it a day.' Dominion 4 July 1996:10. (Reprinted in The Press 6 July 1996, H222. Includes Crump quotes from Barton's 1988 interview, $\underline{\mathrm{H} 143}$ ).

'Glasses raised to a good keen man.' NZ Herald 4 July 1996:1.

Bevan Rapson. 'The man who found the real heart of Kiwidom.' NZ Herald 4 July 1996: 20 (quotes from Terry Sturm: "probably the most read male New Zealand writer ... a damn good storyteller ... Crump's books, which probably deserved greater attention from academics, provided a record of a way of life unavailable anywhere else"; Tessa Duder as President of PEN: "a genuine writer"; and Ray Richards on A Good Keen Man: the manuscript "...really quite an unprepossessing thing", but "Edited, changed from the third person to the first and with Crump's 'fabulous stories' enhanced by the illustrations of Dennis Turner... the best yarn-spinner I have ever met". Graham Scott. 'Bringing to mind the private images of everybody's mate.' NZ Herald 4 July 1996: 20 ("Four images of Barry come to mind. Crumpie, everybody's mate... Crumpie, the loner...; Crumpie, the spiritual man...; Crumpie, the struggling resurrected writer").

Max Lambert, NZPA and Post reporters. 'Barry Crump — a good keen man.' Evening Post 4 July 1996: 7 (with July 1995 photo of Crump and boat and early photo of Crump and dog Flynn).

Max Lambert. 'The passing of Barry Crump — the original good keen man.' Waikato Times 4 July 1996: 2 (with photo; obit.).

Tom Scott cartoon of Crump, captioned "I'm shooting through to see this old man in the sky about a dog" Evening Post 4 July 1996.

Patrick Smellie. 'Best-selling author "Crumpy" dies, 61.' The Australian 4 July 1996: 5 ("The quintessential Kiwi bloke ... died yesterday. Not that Crump ... went in for words like quintessential ... One national television channel observed a moment's silence ... Crump himself acknowledged that the oldfashioned Kiwi lifestyle he represented had changed: 'The 50s and 60s in this country were the best,' he said in an interview last week, 'In our days ... people were trustworthy'.").

Kōtare 4, no. 2 (2001), pp. 3-160. 
myth personified, the author who raised yarning to an art form...").

H213. 'Call was just "a coincidence".' The Evening Standard 4 July 1996: 1 (Two Palmerston North radio breakfast hosts rang the Crump house and spoke to Anton, age eight; half an hour later came the news of Crump's death).

H214. One Network News TV1 4 July 1996 ("Bookstores have experienced increased demand for works by Barry Crump following his death yesterday": New Zealand Television Archive).

H215. 'No warning, says wife.' Waikato Times 4 July 1996:1 ("Barry Crump's wife Maggie says there had been no real warning of ... health problems ...").

H216. 'Crump still had goals — wife. No real warning of health problems until Monday evening.' The Press 5 July 1996: 2 ("... He wasn't afraid of dying. He was a Baha'i... But he belonged to the country — he was a legend really...").

H217. Further obituaries.

'Good bloke shuffles off.' Courier-Mail (Brisbane) 5 July 1996: 16.

'Crump, "a good keen man", dead at 61.' The Daily Telegraph (Sydney) 5 July 1996:36 ("lived the life that thousands of fellow New Zealand men ... envied ... And then wrote about it all...").

'In brief.' Herald Sun (Melbourne) 5 July 1996: 40 ("Writer and actor Barry Crump ... will be fondly remembered as the original good keen man, the archetypal outdoors New Zealander ... He was a man's man").

'Top Kiwi bloke signs off.' The Mercury (Hobart) 5 July 1996: 15.

H218. 'Do it for Crumpy.' Evening Post 5 July 1996:1 ("All Black star Christian Cullen will make Barry Crump a winner if he scores the first try ... New Zealand's famous spinner of yarns, who died on Wednesday, took a punt on Cullen when TAB sports betting began ...").

H219. 'Russell Brown's Hard News.' 5 July 1996.

<http://nz.com/NZ/News/HardNews/1996/1996Tuly05.html> (viewed 27.9.01): "... Anyway, Crumpy's dead. I recall an argument with my Enbglish [sic] teacher in the sixth form about the works of Barry Crump, quite a number of which I had read. Why, I asked, were we always bombarded with these hosannas to Frank bloody Sargeson's working class fiction when surely Crump spoke with a more authentic voice? He was appalled, I was wrong — but I did have a point.

I was fortunate enough to meet Barry Crump last year; he looked like a man cut and carved from the land itself, with a voice to match. I prevailed on him to sign

Kōtare 4, no. 2 (2001), pp. 3-160. 
I was fortunate enough to meet Barry Crump last year; he looked like a man cut and carved from the land itself, with a voice to match. I prevailed on him to sign a copy of his most recent book, an illustrated child's ballad called 'Mrs Windyflax and the Pungapeople'. That book has since become an off-by-heart standard in our house, so I'm glad I did. I'll also never forget him explaining to Kim Hill that his altercation with a traffic officer in Wanaka wasn't so much a dispute with the law, as just 'two blokes getting_off on the wrong foot with each other". If only all the conflict in our country was so simple. Anyway, ta Crumpy, and RIP...".

H220. Helen Bain. 'Crump's special farewell.' Dominion 6 July 1996:1 ("Two Raumati children had never met Barry Crump but were proud to be his grandchildren..."; their father Stephen, son of Crump and Jean Watson).

H221. The Last Word column, Evening Post 6 July 1996: 56: "A statement from the Prime Minister this week bemoaning the loss of good keen man Barry Crump needed some last-minute changes. One of Mr Bolger's press secretaries had been in a bit of a rush, and quoted the Great Helmsman praising Barry for his 'self-sufficiency and self-depreciation'. His what? Self-effacement, apparently, was what he meant. The statement also mentioned Crump's death would leave a vacuum 'in the lexicon of New Zealand characters'. 'Are you sure the Prime Minister knows what a lexicon is?' one gallery wit inquired. 'He probably thinks it's a strange kind of Mexican."'.

H222. Warren Barton. 'Crumpy: a good keen man with a weathered, whiskered, livedin face.' The Press 6 July 1996 (photo of Crump by Mark Round). Reprint of 'Crumpy calls it a day' from Dominion 4 July 1996:10.

H223. Ivan Agnew. 'Crumpy: the original all-round good bloke.' Sunday Star Times 7 July 1996: All (with 1960 and 1982 photos); obit, with personal reminiscences of 1974 interviews (67); "Like his stories, he remains a New Zealand icon whose flaws made him all that more likeable".

H224. Edward Rooney. 'Sons recall differing sides to dad.' Sunday Star Times 7 July 1996: A 3 (photos of Martin and daughter and of stepsons Simon, Anton, Jethro; "Martin said... 'Barry's our little bit of Hollywood ... most people have never met Barry Crump, they met the performer'; confirms there were at least nine Crump sons ... [eldest son] Ivan changed his name by deed poll...").

H225. 'A sentimental Kiwi bloke.' Editorial. Dominion 8 July 1996: 10 ("In Australia, filmmakers had to invent a larger-than-life character ... We had Crumpy ... Barry John Crump did not so much typify the rugged, hard-living, hard-swearing New Zealander as create him ... lived life to a fullness that was the envy of many urban men ... beneath ...there was more of a_thinking man than the image allowed ... Above all, Crump was an uncommonly good storyteller...").

Kōtare 4, no. 2 (2001), pp. 3-160. 
'Funeral for New Zealand author.' TV3 News 8 July 1996 (reporter Bob McNeil; excerpts from graveside speeches by Colin Crump, Martin Crump). 'Special song for Crump.' Evening Post 8 July 1996: 1.

Evening Post 8 July 1996: 3 (Song 'Tall Trees' by Bryce Petersen dedicated to Barry Crump performed at his funeral; photo of coffin being taken from home to the hearse).

'Yarns spun as Crumpy farewelled.' Waikato Times 8 July 1996: 3. "The muddy Toyota ute was parked outside the pub, as if someone had driven into town for a few beers and a yam. But the ute belonged to Barry Crump, and he lay holding his hat in an open casket across the road on the stage of Tauranga's Baycourt Theatre. And this time the yarn had to be told by his mates. 'Good keen man laid to rest.' Dominion 9 July 1996:1. 'A good keen man remembered.' The Press 9 July 1996: 5. Susan Pepperell. "'Spiritual" Crumpy gone bush for good.' Waikato Times 9 July 1996: 2.

Alison Horwood. 'Crump's mates say goodbye.' NZ Herald 9 July 1996: 1 (quotes from eulogies).

Holmes TV1 9 July 1996 ("Close friends pay homage to Barry Crump at his funeral ... yesterday, and relate various anecdotes about The Good Keen Man at a gathering at Straight Shooters Bar": New Zealand Television Archive).

H227. Rosemary McLeod. 'Crump woman was some gal.' 'Broadside' column Dominion 11 July 1996 ("... If I'd had tears to shed last week, they'd have been for all the women ... who've fallen for hard cases like Crump, and for all the Stephens they've had to abandon..."). See H220.

H228. Mark Geenty. 'First-edition books in demand.' The Evening Standard 13 July 1996 (prices of first editions of Crump's books likely to rise; much interest in forthcoming As the Saying Goes).

H229. K. Day. Letter 'Hero Crumpy will live on.' Waikato Times 13 July 1996: 6 ("Crump ... a man who will never know how much he shaped my_formative years. As a teenager ... Crump ... was my hero ... an honest, hardworking straight-up man ... of great character and humour ... I looked at my 3-month old daughter and vowed to enrich her mind and read her excerpts of Barry's books, so the yarns and memory of a good keen man live on").

H230. Art Taulamano. Letter 'A Kiwi legend?' Sunday Star Times 14 July 1996: 12 ("So Barry Crump has been hailed as a multi-talented good keen bloke, a Kiwi legend ... Such a rush to canonise him with these folksy titles is illconceived...").

H231. Karl du Fresne. 'A lifetime spent shooting through.' Evening Post 17 July 1996: 4 (also in Waikato Times 19 July 1996: 6) ("Over the past couple of weeks, New

Kōtare 4, no. 2 (2001), pp. 3-160. 
H231. Karl du Fresne. 'A lifetime spent shooting through.' Evening Post 17 July 1996: 4 (also in Waikato Times 19 July 1996: 6) ("Over the past couple of weeks, New Zealand has indulged in an orgy of sentiment over the death of Barry Crump. Fair enough, too ... a great character, and a naturally gifted writer ... recorded that essential part of New Zealand's heritage for posterity even as it was dying, and he did it with a sharp eye and great wit... Like the characters in his books, he refused to be tied down ...a pretty fundamental failing in a human being, and one that I would have thought rated at least a passing mention in his obituaries ... it's ordinary people leading dull, predictable lives who hold society together.").

H232. Miles Lacey. Letter. 'Crump missed.' Evening Post 18 July 1996: 4. ("Barry Crump is dead. Damn. Who's going to fill the gap that he's left in our literature and culture?").

H233. Kevin Ireland. 'So long, Crumpy.' Listener 20 July 1996: 28. Memories of Crump and the funeral.

H234. Patrick Smellie. 'A ute full of traps, a pen full of words.' The Australian 23 July 1996.

H235. Gordon McLauchlan. 'A keen bloke risks a rhyme or two.' NZ Herald 27 July 1996 7: 9 (Tribute to be published; quotes Ray Richards on publication of $A$ Good Keen Man; "...Crump taught New Zealand writers that they could be funny ...").

H236. 'Barry Crump: an unforgettable man.' The Evening Standard 27 July 1996: 9 (with photo of Crump by Graeme Brown). Wake for Crump held at Martinborough, quotes at length from Kevin Ireland's eulogy: "... unforgettable ... far more complex character than most people thought... possessed of an indomitable, though highly contradictory, dependability ... our greatest teller of the literary equivalent of folk tales ... he was a professional maker of fictions ... snobbery he'd been shown ... one of our finest-ever writers ... placed himself in the mainstream of the longest tradition in world literature ... an extremely gifted stylist... We wrote the first draft of Barry's first story together ... I said I'd type while he recited ... we had several goes at the story during the next few days ... [then] I dropped out altogether ... he worked like a slave at becoming a writer ... a dedicated literary man. He wasn't a writer by some sort of fluke ... he was devoted to his craft. He began A Good Keen Man in 1957, and worked on and off on his manuscript until he finished it toward the middle or end of 1959. Some of the later books may, indeed, have been written in one short burst of great activity. But by then Barry had the knack ... nothing fake or put-on about Barry ... Nothing he wrote about was untrue to the nature of his experience or to his imagination ... he learnt to write the hard way ... the words were all his ... represented in his writings and in his physical presence a romantic notion we have of ourselves as having descended from larger and better people than we are ... Barry invented nothing — especially in

Kōtare 4, no. 2 (2001), pp. 3-160. 
genuine article.".

H237. Stacy Gregg. 'The other life of a good keen man.' Sunday Star Times 28 July 1996: C 1-2 (with photos of Crump women, Martin, and large caricature of Crump by "Bondy"). Account of Crump's relationships with his wives and sons: "Barry Crump was the ideal New Zealand bloke - unless you were married to him... it certainly required courage to be one of Barry Crump's women... wildly temperamental, taciturn and self-absorbed, with a desperate need to constantly be the focus of attention..."; quotes Vanda at length and Martin and Kevin Ireland.

H238. 'What's hot.' Dominion 29 July 1996: 11 (list of bestselling New Zealand books for the two weeks ended July 19 has As the Saying Goes at 2, Life and Times of a Good Keen Man at 3, and Crumpy's Campfire Companion at 7).

H239. 'Tribute to Crump.' Evening Post 29 July 1996: 8 (Radio adaptation of A Good Keen Man read by Bernard Kearns to be rebroadcast — 'Bookshelf'. National Programme weeknights, 10.30pm).

H240. Don Grady. 'Crumpy's Sounds sojourn.' Marlborough Express 31 July 1996: 15.

H241. 'Barry John Crump. Writer, bushman.' Herald Sun (Melbourne) 31 July 1996: 83. (obituary: "the embodiment of rugged resourcefulness and down-to-earth humour").

H242. Iain Macdonald. 'This good keen read sounds fairly dinkum.' Radio review, NZ Herald 10 Aug. 1996 (on rebroadcast of 1962 Bernard Kearns reading of $A$ Good Keen Man - "a pretty fair impersonation of rough-and-ready Enzed enunciation"; account of meeting Crump learning Scarlatti guitar music at time of publication of Bastards I Have Met).

H243. Edward Rooney. 'Crumps welcome a good, keen addition.' Sunday Star Times 11 Aug 1996: A 1. (Son born to Martin and Adele Crump, named Levi Barry; photo).

H244. Michael Stuart. 'Making of the Monde Marie.' Evening Post 28 Aug. 1996: 23 (Mary Seddon recalls her time running the Monde Marie coffee bar in Wellington; "... She had her fair share of embryonic celebrities: Barry Crump. He was with a drunken Maori lady and she got cross, I don't know why. And she stood in the middle of the place and tried to slug me. I really wanted to slosh her one. But one thing I couldn't face was vomit, so I said to Barry, who was sitting there with a silly grin on his face, 'Get her out of here!', and he said 'Oh Mary, you've got to observe life.' and I said 'OK I'll observe life but you hold the basin'."). 
H245. Kevin Ireland. Poem 'Talking about Crump / died 3 July 1996.' Quote Unquote 38 (Aug. 1996): 9 ("first read at a Toyota media conference in Martinborough on July 17, 1996"); reprinted in Anzac Day, Selected Poems. Christchurch: Hazard Press, 1997 (187716111X). 95pp. Pp. 85-6.

H246. Alan Seay. 'A good keen myth.' Metro 183 (Sept. 1996): 68-73. "The full story" of the accidental death of five boys in 1969 at a camp run by Crump and partner George Johnston. Seay was one of the survivors, his cousin died; criticises Crump's "laundered version" of the incident in Life and Times.

H247. Maggie Crump. 'Farewell from a good keen woman.' NZ Woman's Weekly 30 Sept 1996: 36-8. A personal account by Crump's widow of their time together.

H248. Stacy Gregg. 'When a myth is so hard to beat.' Sunday Star Times 8 Dec. 1996: 3 (photo of Crump and of Robyn with her gumboot memorial to him). Robyn Lee-Robinson wants to "tell the truth about Crump" — has written a book about her marriage to Crump - "a novel focusing on a battered wife suffering abuse from a man who goes by the name of Mullet... describes Crump's sudden death as 'extraordinarily frustrating ... Now he's dead, the personal risk is diminished, but the myth is harder to beat'... 'I'm five foot four ... that's not short for a woman at all. But he wanted me to be little ... he would create complexes in people and then take the credit for curing them of their hang-ups' ... It wasn't... Crump's drinking that drove him to violence ... Crump was by and large impotent over the years they were married ... he created the image of a philanderer...").

H249. Letters in response to H248: H. Westfold. 'Crump was a brute.' Sunday Star Times 15 Dec. 1996: 10. ("The revelations by one of the late Barry Crump's exwives were no surprise. In this half-civilised country, brutes like him, if possessed of a minor talent for writing, plus a large one for self-publicity, have an extremely good chance of becoming folk heroes for macho men..."). C.P. Heron. 'Why celebrate macho men?' ibid. ("... the truth about the real person under the image is slowly being revealed. How many other women have suffered in relationships with men clinging to this pathetic image of a real man? The sooner the myth of the good keen man is destroyed, the better").

H250. Neil Clarkson. 'Balthasar's billy' (after Barry Crump), in: 'Once upon a starry night. Other journeys of the magi.' The Press 21 Dec. 1996, Weekend: 1. "Three wise men came out of the East following a star and bearing gifts. Four writers from 'The Press' pay homage to the story in the style of authors who have featured in the Weekend section during the last year". Parody of Crump.

H251. Kai Jensen. Whole Men, The Masculine Tradition in New Zealand Literature. Auckland: Auckland University Press, 1996.18640145X. 202pp. Crump pp. 3, 12, 17 ("It's possible that writers like Sargeson, rather than simply_recording and reflecting popular masculinity ... actively shaped a 'tradition' about New Zealand manhood, which was picked up, amplified and broadcast by popular 
writers such as Barry Crump and Sam Hunt and cartoonist Murray Ball..."), 175.

Review: Carl Davidson NZ Herald 13 April 1996 (".. .the fact that Barry Crump remains New Zealand's best-selling author suggests there are more of us who still have some sympathy with the 'whole man' ideal, or some fascination with masculinity, than others of us would like to acknowledge...").

H252. Barry Crump: A Tribute to Crimpy, 1935-1996. Auckland: Hodder Moa Beckett, 1996.1869584449. Ills. 216pp., dark green boards, $\$ 49.95$ (paperback reprint 1997. 216pp. 1869585844. \$39.95).

Memories of Crump from friends and family. There is an editor's note but the editor is not named. Includes extracts from Crump's books, poems, letters, and the first chapter of his last, unpublished, book. Contents (* indicates interviewed by Kirsten Warner): Foreword by Maggie Crump pp.[9-10].

Introduction by Colin Hogg pp.[13]-28 [reprinted with alterations from his article 'Wandering Star', Southern Skies Aug. 1994; H175]. Chapter 1 'One of Us' pp.[29]-45: pp.32-39 by Bill Crump* ("Barry's Older Brother"); pp.42-[45] by Colin Crump* ("Barry's Younger Brother"), including poem 'Brother Barry' p.[45].

Chapter 2 'A Good Keen Man' pp.[46]-[77]: pp.48-51 by Selwyn Bucknell* ("Former Field Officer"); pp.52-9 by Jack Lasenby* ("Hunter and Writer"); pp.60-72 by Kevin Ireland ("Writer"); pp.73-5 by Ray Richards ("Original Publisher of Barry Crump's Books").

Chapter 3 'A Good Keen Girl' pp.[78]-117: pp.80-1 by Tina Lester* ("Barry's First Wife"); pp.82-8 by Martin Crump* ("Barry and Tina's Son"); pp.90-4 by Andrew Campbell ("Son of Fleur Adcock — Barry's Second Wife"); pp.96-7 on Jean Watson; pp.98-9 on Janet Vanda Lyndon ("Barry's Third Wife"); pp.100-3 by Simone Rainger* ("Daughter of Barry's Girlfriend, Lenna"); pp.104-7 by Robin Lee Robinson ("Barry's Fourth Wife"; changed spelling from "Robyn": p.180 \& Editor's note p.[4]); pp.108-10 by Maggie Crump ("Barry's Widow"); pp.110-1 by Jethro Crump ("Barry's Stepson"); pp.112-3 by Simon Crump ("Barry's Stepson"); pp.115 by Anton Crump ("Barry's Stepson"); pp.116-7 by Stew Nicholson ("Brother-in-Law"). Chapter 4 'Bastards I Have Met' pp.[118]153: pp.120-2 by George Johnson* ("Fellow Hunter"); pp.124-7 by Jon Zealando* ("Magician"); pp.128-30 by_Bryce Peterson ("Musician and Fellow Baha'i"); pp. 132-6 by Ted and Chris Clark* ("Golfing Companions"); pp.13842 by Alex King ("The Holder of the Nugget of the Tattooed Leg"); pp.144-6 by Helen Rasmussen ("Fellow Whitebaiter"); pp.148-51 by George Wilson ("Goldpanner"). Chapter 5 'Gold and Greenstone' pp.[154]-[173]: pp.156-8 by Barbara Magner* ("Town and Around Journalist"); pp.160-2 by Cliff Josephs* ("Former Publisher"); pp.164-7 by Lloyd Scott* ("Scotty in the Toyota Commercials"); pp.168-70 by Bob Field* ("Managing Director of Toyota New Zealand"); p.171 'Toyota' poem by Barry Crump [also in Song of a Drifter; here no comma after

Kōtare 4, no. 2 (2001), pp. 3-160. 
'Haast']; pp.172-3 by Craig Howan* ("Former Manager"). Chapter 6 'From the Letterbox' pp.[174]-[198]. Twelve letters written by Crump and one to him.

Chapter 3 'A Good Keen Girl' pp.[78]-117: pp.80-1 by Tina Lester* ("Barry's First Wife"); pp.82-8 by Martin Crump* ("Barry and Tina's Son"); pp.90-4 by Andrew Campbell ("Son of Fleur Adcock — Barry's Second Wife"); pp.96-7 on Jean Watson; pp.98-9 on Janet Vanda Lyndon ("Barry's Third Wife"); pp.100-3 by Simone Rainger* ("Daughter of Barry's Girlfriend, Lenna"); pp.104-7 by Robin Lee Robinson ("Barry's Fourth Wife"; changed spelling from "Robyn": p.180 \& Editor's note p.[4]); pp.108-10 by Maggie Crump ("Barry's Widow"); pp.110-1 by Jethro Crump ("Barry's Stepson"); pp.112-3 by Simon Crump ("Barry's Stepson"); pp.115 by Anton Crump ("Barry's Stepson"); pp.116-7 by Stew Nicholson ("Brother-in-Law"). Chapter 4 'Bastards I Have Met' pp.[118]153: pp.120-2 by George Johnson* ("Fellow Hunter"); pp.124-7 by Jon Zealando* ("Magician"); pp.128-30 by

Chapter 7 'Writings' pp.[199]-215: pp.202-5 'Opportunity' first chapter of his planned next book 'The Return of Sam Cash' [shorter version, with minor differences, in Hogg Loose Strides pp.194-5]; Poems: p.206 'Fire' [also in Crumpy's Campfire Companion and Song of a Drifter, minor differences]; p.207 'Time of Day' [first in Bush Telegraph (드); also in Bedtime Yarns and Song of a Drifter]; pp.208-9 'Ode to a Politician' [also in Song of a Drifter]; p.210-11 'Bad Blue' [released on record as a 'A Dog Called Blue', 1970 (El); also in Song of a Drifter; slight differences; misprint here 'it' for 'its' first stanza]; pp.212-3 'Harry's Piece of Pain' [also in Bedtime Yarns and Song of a Drifter; here 'heavy-lidded' stanza 1]; p.214 'Cup of Tea' [also in Song of a Drifter; here no comma after 'court' stanza 3, misprint 'indications' stanza 5]; p.215 'Journey' [also in Bedtime Yarns and revised in Song of a Drifter; here as latter with slight punctuation differences]. Extracts reprinted:

The article by Bryce Peterson is reprinted in the Baha'i publication Herald of

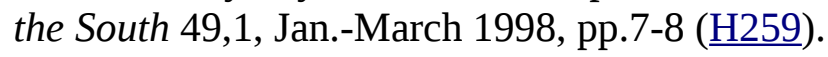

Extracts from the pieces by Cliff Josephs and by Colin Hogg are included with comprehension questions in an online "Reading Comprehensions" series by Mark Osborne at <http://www.geocities.com/Athens/Aegean/9366/comps/yrl0crump.htm> ("Copyright 1999. Last Updated 6 February 2000"; viewed 20.9.01) Reviews:

Karl du Fresne. 'Reflections on the life of a Good Keen Man.' Evening Post 10 Jan. 1997 (criticises Hogg's introduction — "recycles all the familiar Crump mythology. Skip it. ... [Crump's] almost pathological restlessness ... He demanded a lot of his friends, but he gave a lot too...").

Louise van Uden. 'Barry Crump remembered.' The Southland Times 11 Jan. 1997: 26 ("a beautiful book and a great tribute to a New Zealand icon"). Neil Clarkson. 'Farewell to Crump.' The Press Feb. 221997 Weekend: 14 ("a

Kōtare 4, no. 2 (2001), pp. 3-160. 
Michael King. Metro 189 (March 1997): 108-9 ("a man with an inspired sense of humour, considerable powers of story-telling and a capacity for selfinvention that was equalled only by James K. Baxter"). Graeme Lay. North and South 132 (March 1997): 124 ("The Australians had to invent Crocodile Dundee. We had a real one...").

H253. 'One Extra' One Network News TV1 2 Jan. 1997 (Crump included in a "retrospective tribute to people in the news who died in 1996": New Zealand Television Archive).

H254. Max Lambert. 'Two true-blue Kiwi characters.' Evening Post 2 Jan 1997: 5. Commemorating Crump and mountaineer Rob Hall among notable New Zealanders who died in 1996.

H255. Judith Paviell. 'Bronze bust finds new home.' The Evening Standard 14 Feb. 1997: 16 ("The archetypal Kiwi bloke, the late Barry Crump, immortalised in bronze by Marton sculptor Robin Coleman, now has a new home at Manawatu Toyota, Palmerston North ... made in 1993 ... from a photograph in Crump's first book ...").

H256. 'New Zild.' One Network News 28 July 1997 (Crump mentioned in report on Canterbury University study of New Zealand speech: New Zealand Television Archive).

H257. Harry Orsman, ed. The Dictionary of New Zealand English, A Dictionary of New Zealandisms on Historical Principles. Auckland: Oxford University Press, 1997. 01955583477, cased; 01955583809, leather-bound. xvi,965pp. Cites Barry Crump's Bedtime Yarns, Bastards I Have Met, A Good Keen Man, Hang on a Minute Mate, One of Us as sources for words and expressions. The entries in the book are also accessible as part of the New Zealand Dictionary Centre database which includes material collected by Orsman but omitted from the book and material collected subsequently ('Incomings'). The Crump entries in the DNZE and Orsman sections together number 364 (including duplicates common to both: approximately 286 individual_entries), with some forty-one entries (at 11.5.01) in 'Incomings' both by Crump (among them 'a few in', 'berko', 'gorgy', 'shoot through', 'rat bag', 'hard-case', 'hoot', 'horsable') and by others about or alluding to him (e.g. 'Crumpy-esque', 'Crumpish', 'Crumpism', 'a callow Barry Crump phase of youth', and 'a good keen man' used by several other writers).

H258. Ian Richards. To Bed at Noon, The Life and Art of Maurice Duggan. Auckland: Auckland University Press, 1997. 186940159X. xi,463pp. Crump: p.218 (his greeting to Bob Lowry at the Pilgrim Press, and the reply); pp.299-300 (Duggan's attitude to Crump — "had been watching Crump's rise in New Zealand literature since 1960 with quiet dismay..."; Shadbolt drafts publishing contract for Crump; marriage to Fleur Adcock; "...with professional and perhaps personal jealousy, Duggan described Crump [to Fleur] as 'the anecdotal ape'...";

Kōtare 4, no. 2 (2001), pp. 3-160. 
contract for Crump; marriage to Fleur Adcock; "...with professional and perhaps personal jealousy, Duggan described Crump [to Fleur] as 'the anecdotal ape'..."; "crumpy conversation"); pp.304-5 (Fleur's fare to UK); p.306 (Duggan story and Fleur poem in Landfall March 1963; $\underline{\text { H27, }} \underline{\text { H28); }) ; ~ p .334 ~(D u g g a n ~ a n d ~ C r u m p ~}$ drinking mates); p.382 (learns Crump now a Baha'i).

H259. Margot Macphail. 'The quintessential New Zealand man.' Herald of the South 49, 1 (Jan.-March 1998): 6-8 (article on Crump and on his Baha'i faith; quotes from Peter Williams's graveside tribute; poem 'On the eve of Barry's death' by Macphail; Reuter report of Crump's death; reprint of Bryce Peterson's 'Tribute' from Tribute).

H260. 'Beyond a Joke.' TV1 4 April 1998. Television documentary about the New Zealand sense of humour, including Crump. (Copy held NZ Film Archive).

H261. 'Research shows New Zealand men are succumbing to political correctness and are confused and intimidated.' TV3 6 April 1994 (reporter Craig Dowling; includes film footage of Crump Toyota ads).

H262. 'Crump's children challenge his will.' Dominion 20 June 1998.

H263. Elinore Wellwood. 'Lawyers seek Crumpy's lot.' The Press 24 June 1998 p.2 ("Lawyers are looking for good keen man Barry Crump's love children, possibly spawned as he roamed the South Island high country ... Given the number of relationships he had, the court required the advertisement ...").

H264. 'The Measure of a Man.' Assignment TV1 25 June 1998 (Crump included in "a look at the changing face of the Kiwi (New Zealand) man": New Zealand Television Archive).

H265. Maggie Crump. 'Letters to Crumpy.' NZ Woman's Weekly 6 July 1998: 27-8.

H266. Warwick Roger. 'Opinion' column Evening Post Oct. 191998 (critical of Barry Crump, Colin Meads, Gary McCormick: where is the real person behind the icon?).

H267. Letter in reply to $\underline{\text { H266 }}$ by John Gill 'Real Kiwi blokes — may God bless them' Evening Post 22 Oct. 1998: 4.

H268. Pat Veltkamp. 'Shadow still hangs over Scotty.' The Southland Times 12 Nov. 1998: 12 (Self-compiled show 'Me and my shadow' on the Toyota ads presented by Lloyd Scott to Invercargill Coffee Club; "... thought he could probably do better than answer questions about life without Crump. It is a question asked frequently enough for him to have a reply that at first it was half a life but it was coming together now. Lloyd Scott and Barry Crump were an inspired

Kōtare 4, no. 2 (2001), pp. 3-160. 
him. When he died, people rang up asking all these questions about Barry Crump. It was Crumpy I knew.' His audience remembered every ad and wanted more, so he told of the many bits that weren't shown and said out loud the throwaway lines missed at the end - like Crumpy asking 'do you take sugar Scotty', and at Scotty's 'no', saying 'Well, just don't stir your tea.'.").

H269. Roger Hall. Bums on Seats, The Backstage Story. Auckland: Viking, 1998. 0670883662. 292pp. Crump p.114: "[while editor of Education] I got writers to describe the books that had influenced them in their early childhood... " (see $\underline{\text { A13). }}$.

H270. Colin Hogg. The Awful Truth: An Unauthorised Autobiography. Auckland: Hodder Moa Beckett, 1998.1869586999.197pp. Recollections of Crump Chapter 27 'Not good, not keen' pp. 193-7: the title from a comment by Crump's former wife Robyn describing him as "not good, not keen, but_dead"; account of interviewing Crump on LSD, the interview for Southern Skies, research for the TV documentary. The back cover terms Hogg "an alternative sort of good keen man".

H271. Elizabeth Gordon and Tony Deverson. New Zealand English and English in New Zealand. Auckland: New House, 1998. P.136: "Broad New Zealand speech is associated with people such as the late Barry Crump and suggests a farmhand wearing a black singlet and gumboots".

H272. Kevin Ireland. Under the Bridge \& Over the Moon, A Memoir. Auckland: Vintage, 1998. 1869413636. 166pp. Crump p.155: "... Tina Anso's house in New Lynn, where I sat down before a typewriter with Barry Crump and announced that we were about to commit his first story to paper, a story that subsequently was transformed into chapter eight of A Good Keen Man...".

H273. Max Cryer. Day by Day, A Kiwi Collection. Auckland: Hodder Moa Beckett, 1998. 1869587219. 392pp. Crump p.74: "... in 1960 a voice emerged which seemed to capture the resonances of middle-class New Zealand"; photo p.[71].

H274. Jim Henderson. From Top to Bottom, Reinga to Bluff. [Auckland]: The Radio Pacific Network [1998]. 0473049309.142pp. Crump pp.40-1 (incl. photo with Peggy Dunstan): "... Read too his classic New Zealand horror story 'Never come at that mate"' [i.e. probably 'That way': $\underline{\text { A3] }}$... four stories in the first of the Open Country books "blew to smithereens the Golden Memories of the Happy Valley school of New Zealand writing".

H275. David McGill. David McGill's Complete Kiwi Slang Dictionary. Auckland: Reed, 1998. 0790005956.143pp. "New Zealand writers and social commentators have yielded much slang..." (p.4). (Crump named as source in H146). 
$\underline{\mathrm{H} 146})$.

H276. William J. Schafer. Mapping the Godzone, A Primer on Nezv Zealand Literature and Culture. Honolulu: University of Hawaii Press, 1998.0824820169. xvii,197pp. Crump p.xiii: "In chapter 3, 'The Last Big Islands', I examine the mythic background of Maori culture and relate that to two versions of New Zealand's classic pakeha Man Alone myth, John Mulgan's Man Alone and Barry Crump's Wild Pork and Watercress..."; pp.70-7 the section referred to_above — 'The Man Alone Myth: Redemption through Skill' — Crump "a careful observer and a skilled storyteller", the book "an improbable adventure of mentor and acolyte with important moral and social reverberations ... message of reconciliation of self with nature and individual with family ... [Crump's] version of the Man Alone has the same mythic resonance as John Mulgan's, and its basic ideology is more constructive and salutary...".

H277. Terry Sturm: entries for 'Barry Crump' and for 'A Good Keen Man' in Roger Robinson and Nelson Wattie, ed. The Oxford Companion to New Zealand Literature. Melbourne: Oxford University Press, 1998. 0195583485. xvi,608pp. The first article is also available online at <http://www.vuw.ac.nz/ nzbookcouncil/writers/crumpbarry.htm> (viewed 29.9.01).

H278. Family dispute over Crump's will:

One Network News TV1 15 Feb. 1999 (New Zealand Television Archive). 'Family settles dispute over Barry Crump's will.' Dominion 16 Feb. 1999:1. 'Crump's will settled.' Evening Post 16 Feb. 1999: 2. 'Dispute over Crump will settled.' Otago Daily Times 16 Feb 1999: (longer version) "New Zealand icon Barry Crump can rest in peace following settlement of a dispute over his will. The 61-year-old author left his entire estate to his fourth wife, Maggie. But that brought a challenge from at least two of his nine children ... Son Martin Crump, who filed the proceeding under the Family Protection Act, issued a brief statement saying the dispute was settled...".

H279. Previews of television documentary $(\underline{\mathrm{H} 280})$ :

Colin Hogg. 'A Good Keen Man?' NZ Herald 18 Feb. 1999: D 3 (profile of Crump and discussion of making the documentary).

Denis Welch. 'Blood on the tracks.' Listener 20 Feb. 1999: 32-3. Preview of the documentary: "Good keen man Barry Crump was also a wife-beater and tortured artist ... a very complex man .... 'superb con': Jack Lasenby ... a cultural signifier of the first rank. He just about singlehandedly eased the pain of New Zealand's postwar cultural transition to a predominantly urban society. As we settled down to increasingly tame domestic lives, he was the jester assuring us that we were still rugged, resourceful pioneers at heart ...he conquered people, even imposed his language on them. The people who knew him keep using 
initially intended to be more of a tribute... still pays tribute to Crump as a writer and public personality while not hiding his dark side as a man ... Crump first popularised, then personified and finally parodied the Man Alone myth that has run through this country's literature like a strand of No. 8 wire ... The coup de grace was the Toyota ad campaign of the 80s and 90s in which Man Alone tackled the wilderness in a Japanese car ...".

Linda Herrick. 'Dark side of the good keen man. Crump women tell of their hell.' Sunday Star Times 21 Feb. 1999: 6 (with five photos; previewing documentary).

Anamika Vasil. 'Crump: another side to the "Good Keen Man".' Dominion 22 February 1999: 23. "It's been two years since the death of one of New Zealand's most well-loved heroes ... - time enough it seems for a documentary that could show him in a less than flattering light...". 'A good keen man.' Evening Post 22 Feb. 1999:10 (previewing documentary).

H280. Crump-A Wandering Star, television documentary, TV1,26 Feb. 1999. Made by Greenstone Pictures. Director Michelle Bracey, Producer Philippa Mossman, Interviewer and Writer Colin Hogg, Narrator Barry Jenkin. The documentary won Best Script at the 1999 NZ TV Awards. (Copy held NZ Film Archive; 72 min.)

\section{H281. Reviews and responses:}

Jane Bowron. 'Struth! What a way to treat a mate.' Dominion 27 Feb. 1999.

Review of documentary - "It's a bloody nuisance being dead. Especially when some bastards I have met try and air your dirty washing in public ...". 'Holmes Show looks like becoming circus.' Otago Daily Times 27 Feb. 1999 (online at $<$ http://www.odt.co.nz/?issue=1999/27Febl999> under 'Other items': viewed 29.0.01): television review — " ... Crump — a Wandering Star offered a frank view of the life of Kiwi icon, bushman, author and 'good keen man' Barry Crump ... an excellent job in searching for the reality under the myth ... he was enough of a con man to remake and rediscover versions of himself every few years ... a sad story in which he became a parody of the tough New Zealand male ...".

Peter Hawes. 'Crumpy's awful life shrouded in myth.' Sunday Star Times 28 Feb. 1999: F 7. Review of documentary — "...no one really wants their literature written by violent misogynists, so we dabble in a little creative fiction of our own... The Crumpian truth was to be confined to the novels.... Crump's sister: 'He didn't want to hurt anyone...That's why he always moved on' ... Curiously, this dreadful man wrote from love..."; brief account of meeting Crump in the mid-60s.

Rev. Dr David Bromell. 'Shooting Through, A sermon on Genesis 12:1-4a and Romans 4:1-5,13-17.' Lent II — Sunday 28 February 1999 (available online 
Rev. Dr David Bromell. 'Shooting Through, A sermon on Genesis 12:1-4a and Romans 4:1-5,13-17.' Lent II — Sunday 28 February 1999 (available online $<$ http://www.niethodist-mission-chch.org/sermon-shootingthrough.htrn>. viewed 29.9.01): "I watched the documentary about Barry Crump on Monday night... when he didn't like how he was behaving, he'd shoot through ... When the road runs out, shoot through. Those Toyotas will take you anywhere, Scotty. So when it's turning ugly, shoot through ... At one stage, he shot through to India, looking for God ... The history of Israel begins with the Exodus from Egypt â€” shooting through ... There's a lot of 'shooting through' in Genesis, come to think of it...".

Barry Hawkins. 'Wanted a good keen newsreader.' Evening Post 1 March 1999: 2. Includes review of television documentary: "He put a lot of noses out of joint — not just with his fists... we got a generally sympathetic picture of a bloke with a special, raw ability to tell simple stories...". Shannon McLeigh. Letter 'Barry Crump' dated 24 Feb. Nelson Mail 1 March 1999: 9 ("... documentary on Barry Crump. I don't know what the programme was called but it should have been: 'No one likes a con'").

H282. 'Brief — Books'. Sunday Star Times 14 March 1999: 4 ("Hodder Moa Beckett is to publish a Barry Crump biography which should be on sale by Christmas. It is also planning to release five previously unpublished children's books by Crump this year").

H283. 'Turning to the land for a sense of peace.' Otago Daily Times 16 March 1999 (online at <http://www.odt.co.nz/?issue=1999/16Marl999> under 'Editorial'): "I went with my wife and two daughters to ... a place called Maraetotara Falls ... I found another world awaiting me - a crystal clear river flowing through a small cutting of tree-covered banks ... I'm one of those seriously guilty of not looking at the nature side of his country properly. I shall change that forthwith ... We can't change what we are. But we sure as heck can change what we do with our lives, given that someone or something enlightens us. Barry Crump's Good Keen Man came out when I was a teenager. My older brothers, keen hunters, devoured the book. It sold huge numbers of copies. And despite the precious, irrelevant literati sneering their cruel, ugly faces at it, it went on to make Crumpy a celebrated identity because he reflected what we are as New Zealanders a whole lot more than_the stuffy, navel-gazing literary set. Which is why people are busy pulling Crump down after his death, because we can't stand to have heroes, especially not a mere working-class hunter."

H284. 'CM Research Study shows most of New Zealand in a positive frame of mind.' TV3 17 June 1999 (reporter Mark Jennings; includes film footage of Crump Toyota ads).

H285. '100 Great New Zealanders of the 20th Century.' Listener 3 July 1999: 18. Crump included in this list of "heroes, anti-heroes, celebrities, everyday people, icons ... the cast of the national drama" with note "Increasingly suburbanised 
Reprinted in Denis Welch, ed. The Listener Bedside Book No.3. Auckland: W \&H Publications, 1999.1877214086. 304pp. Pp.127-9.

H286. Claire Logan. 'One of the nice guys.' Sunday Star Times 3 Oct. 1999: D 2. Interview with Lloyd Scott: "Claire Logan catches up with Scotty post-Crump. He will always be best known as the nervous sidekick of Crumpy ... forever shackled to the memory of the original Good Keen Man ...".

H287. Maurice Shadbolt. From the Edge of the Sky, A Memoir. Auckland: David Ling, 1999 (0908990596). 238pp. Crump: pp.78-82 (Crump and Jean Watson in same Wellington house as Shadbolt; their breakfasts; "I had written out Crump's first literary contract, the most enriching a New Zealand author has ever had"; Watson's "delicate little tale of her days on the road with Crump, Stand in the Rain, would be far more impressive than anything Crump ever published"; (March 1975) Crump visits Shadbolt at Titirangi, refusing a beer and announcing himself a Baha'i; chance meeting at a pub in London); p.211 (on Fleur Adcock: "the boozy and wife-bashing Barry Crump"). Reviews:

Gordon McLauchlan. 'From Shadbolt with no love lost.' NZ Herald 24 April 1999: J 1 (interview with Shadbolt about the book).

Peter Mann. 'Shadbolt's memoir invaluable folklore.' Otago Daily Times 26June 1999 (online at <http://www.odt.co.nz/?issue=1999/26Tunl999> under 'Features': viewed 29.9.01): "... beautifully crafted account of a journey through his growth as a writer, a husband of several wives, a family and a close acquaintance of many New Zealand writers ... it is the author's association with other writers that defines his own approach to his craft. He is merciless on failures, such as Barry Crump, compassionate with those who met ill-fortune, such as Maurice Duggan, and gentle with female writers and poets, such as Sylvia Ashton-Warner, Fleur Adcock and Marilyn Duckworth ...".

H288. Fleur Revell. 'Like father, not son.' Sunday Star Times 10 Oct 1999: D 5. Interview with Martin Crump.

H289. 'Kiwis of the Century. Readers' Choice.' Evening Post 30 Nov. 1999. Sir Edmund Hillary rated top in a poll to choose "100 significant Kiwis from the past 100 years" ... "Nearly 40 Kiwis Of The Century rated more than 5 percent. Among them were ... Four writers: Katherine Mansfield 24, Barry Crump 18, Janet Frame 9, James K Baxter 7.5 ...".

H290. Ruth Nichol. 'Chapters of the century.' Evening Post 30 Nov. 1999:19 ("From the 1830s to the 1990s, New Zealand has been a publishing nation, but the giant strides were made ... by the publisher Reed, which marched, in company with writers such as Barry Crump, into the imagination of middlebrow New Zealand ... Crump...now undergoing something of a reassessment - it seems he had a dark side to his sunny exterior. ..";A Good Keen Man included in "Top 10

Kōtare 4, no. 2 (2001), pp. 3-160. 
had a dark side to his sunny exterior. ..";A Good Keen Man included in "Top 10 New Zealand books of the century").

H291. A paper 'Southern Men and Highlanders: Commercial branding, tourism and regional senses of place' presented by Geoff Kearsley at The International Geographical Union Sustainable Tourism Study Group \& International Tourism Students' Conference, at Oamaru in 1999 (also presented in Sheffield) "explores the role of the South Island High Country in New Zealanders' self imagery and popular culture, through regional artists and the writings of such authors as Barry Crump", according to the abstract at $<$ http://divcom.otago.ac.nz:800/tourism/Oamarul999-abstracts.htm> (viewed 10.10.01); the paper is not included in the published proceedings.

H292. Caroline Daley and Deborah Montgomerie, ed. The Gendered Kiwi. Auckland: Auckland University Press, 1999.1869402197. 256pp. Crump p.20 in Charlotte Macdonald's article 'Too many men and too few women: gender's "fatal impact" in nineteenth-century colonies' pp. 17-35: "... Pioneer man increasingly became legend rather than reality. Yet this image of mas-_culinity has persisted and continues to command a central place in popular and literary culture in figures as disparate as John Mulgan's Man Alone, Barry Crump's Good Keen Man and beer brewer Speight's' 'Southern Man'...".

H293. George Johnston. The Old Dynamite Shack: Crump - The Untold Stories. Auckland: Reed, 1999. 0790006928. 213pp. "Barry Crump's old mate George shares some of the hilarious adventures that these two Kiwi blokes got up to together. Written in classic 'Crumpy' style!" — publisher's description on website <http://www.reed.co.nz/products.cfm?view=353\&catID=8> (viewed 30.9.01).

For George Johnston (called "Henry" by Crump in his books) see Hogg Loose Strides pp.103-4,106,108-14,126,195-6; contribution to Tribute pp.120-2.

Reviews:

Stephen Jacquiery. 'Hunting and humour abound.' Otago Daily Times 3 Nov 1999: 24 (online at <http://www.odt.co.nz/?issue=1999/03Novl999> under 'Features': viewed 30.9.01): "... Outrageous, ingenious, boozy, sexist, but most of all good fun, he focuses on three dogs and two men as they leave their mark on the back country".

Mike Crean. 'Book Marks.' The Press 7 Oct. 2000 Weekend: 15: "Johnston cashes in unashamedly on the posthumous fame of his old mate, Barry Crump, in this collection of stories ... Johnston explains that these are stories of his adventures with Crump though he writes of himself in the third person as Henry Bruckner. Johnston writes crisply and well, but the yarns remain fairly run-ofthe-mill, perhaps explaining why Crump did not bother to include them in any of his books. For all that, this is a convincing look at some hard-case Kiwi

Kōtare 4, no. 2 (2001), pp. 3-160. 
H294. Robin Law, Hugh Campbell, John Dolan, ed. Masculinities in Aotearoa / New Zealand. Palmerston North: The Dunmore Press, 1999. 0864693257. 259pp. Crump: Introduction p.14 ("...This mythological male looms larger than life, begging the question as to why there is no female equivalent to Barry Crump in the national identity"); p.20 (Crump as an example of how "Intertextual linkages take on a kind of immediacy and urgency, as some authors present themselves as 'real life' versions of the Kiwi blokes portrayed in their creations"; refers to Crump's Toyota ads and suggests that in the Speights Southern Man beer ad "alert New Zealand viewers recognise that the unnamed older character bears a striking resemblance to Crump"); p.59 (Ruth Schick and John Dolan, interviewing Jock Phillips — "You laugh at_Barry Crump because you identify with the type, and yet you've moved sufficiently away that you can also begin to see that it is now exaggerated...").

Press release on the book online at <http://www.otago.ac.nz/news/ press releases 71999 712-08-99 press release.html> (viewed 17.5.01): "New Book Examines the Myth of the Kiwi Male - and Reality ... In attempting to define the New Zealand male, the editors nominate icons like writer Barry Crump, All Black Colin Meads, and — in parody — Fred Dagg...". Review: Charmian Smith (interviewing editors Law and Campbell). 'Myth and reality of Kiwi "good keen man".' Otago Daily Times 1 April 2000 (with photo of Crump; online at <http://www.odt.co.nz/?issue=2000/01Apr2000> under 'Other items': viewed 30.9.01): "...You would be hard pressed to find a real southern man, a real Kiwi bloke - after all, we all know he is a myth but that does not stop the image being a powerful cultural influence ... 'How many people were really like Barry Crump and was he really like what he made himself out to be? The deerculling, pig-shooting bushmen really weren't that many. But if enough people believe and act on that belief then it's true in its effects,' says Dr Hugh Campbell...".

H295. Millennium Moments, Great Days in New Zealand History. [Foreword by Richard Long]. Auckland: Published under license from TVNZ Enterprises by Reed Books, 1999. 0790007126. 214pp. (From TVNZ series of the same name, chronicling "365 notable events from New Zealand's history" — Foreword). Crump p.45: "7 March 1960 - A Good Keen Man published" with photo of dust-jacket; New Zealand Television Archive holds compilation tape of "Air New Zealand Millennium Moments").

H296. Grant Bourne \& Sabine Korner-Bourne. New Zealand. 2nd ed. Ashbourne: Landmark / Edison, N.J.: Hunter, C1999. 319pp. 1901522369. Guidebook to New Zealand; Crump included in section on 'Literature' p.13.

H297. Gordon Ogilvie. Denis Glover: His Life. Auckland: Godwit (Random House), 1999.1869620380. 544pp. Crump pp.336,339 (brief mentions: visitor to Glover at Paekakariki; published by Reed).

Kōtare 4, no. 2 (2001), pp. 3-160. 
at Paekakariki; published by Reed).

H298. John O'Shea. Don't Let it Get You, Memories — Documents. Wellington: Victoria University Press, 1999. 0864733569. 206pp. Crump pp.34-6: Crump [and Jane Campion] "similar to Celine ... he claimed to have absorbed from_the world around him characters in whom one cannot perceive any cant or cover-up, unless it's there intentionally..."; "we worked together on an adaptation of his novel Gulf ... working with Barry...was realistic, amiable and productive"; "Gradually I came to know how much [Jean Watson] had meant to him ... Stand in the Rain and Address to a King are lyric and loving testimonies to the rough and ready style of life with him".

H299. Victoria Clausen. 'Kiwiana. It's a bit of a dag, really.' Millennium Review. The Press 1 Jan. 2000: 37: "There's no end to the things you can do with a length of No. 8 wire. It's all part of our crackerjack, down-to-earth Kiwi culture ... A good keen man with a healthy dose of Kiwi ingenuity and the ability to turn a piece of No. 8 wire into all manner of useful household objects epitomised New Zealand's hard-man culture in the 20th century. People like Barry Crump, a Kiwi bloke who told a few yarns and wrote a few books...".

H300. Anthony Hubbard. 'New dawn new identity.' Sunday Star Times 2 Jan. 2000: A 1: "Do we have a national identity? Anthony Hubbard went searching for answers as we enter the new millennium ... The good keen man. This is Barry Crump's refinement of an older figure in the national mythology, the laconically humorous rural man who can turn his hand to anything. He dislikes women but he knows exactly what to do with a sheep. Crump's man, though, was a bucolic myth in an age of urban living. The celebration of the versatile Kiwi - the fellow who can do anything with a piece of Number 8 wire - has deep roots ...".

H301. Denis Dwyer. 'Bushtales.' The Evening Standard 22 April 2000: 11. (Hunting reminiscences; "...In the Top House pub on the West Coast, or in the Wairau pub, he would sometimes run into legendary bushman and author Barry Crump. 'He was a bit of a bullshitter, but he was all right,' Owen says ..."; quotes Crump).

H302. Carl Nixon. Crumpy. A Play about the Life of Barry Crump. Premiered at Court 2 Theatre, Christchurch, July 15 to Aug. 12 2000; directed by David McPhail; three actors, Russell Smith as Crump, Fionnuala Kelly and Mick Innes playing all the other characters. Also performed at the Nelson Arts Festival, 14-16 Sept. 2000; Fortune Theatre, Dunedin, 18-28 April 2001 (preceded by Otago and Southland tour 28 March-7 April; directed by Rex Simpson, Jon Waite as Crump).

Commentary, previews and reviews:

"Crumpy puts on stage the life and times of New Zealand's best known

Kōtare 4, no. 2 (2001), pp. 3-160. 
memory with Barry Crump — up close and personal." -

$<$ http://naf2000.nelson.co.nz/stories/storyReader\$15> (viewed 11.5.01).

'Our People.' One News TV1 24 June 2000 ("...Barry Crump ... about to have his story told on stage...": New Zealand Television Archive).

Jo McCarroll. 'Both sides of Crumpy.' Sunday Star Times 25 June 2000: F 3 (photo of Carl Nixon and of poster for the play; "...The idea came from audiences' responses to the mention of Crump in one of Nixon's earlier plays, $A$ Complete History of New Zealand (Abridged) ... Barry Crump was mentioned at one point and the audience had this real response to it. They really related to him... It would have been easier to write a bushman's romp, but as Nixon researched Crump's life he found his private life was almost diametrically opposed to his public persona ...".

Christopher Moore. 'Crumpy old man.' The Press 5 July 2000: 34 (Crump's son Lyall approached the producer to play his father; "almost none of the words in the play is original Crump — 'because of copyright, you can't rip off people's words'. Most is written 'in the style of Barry Crump' ...".

'Play ... to open in Christchurch.' TV3 14 July 2000 (reporter Aimee Burke; interview with David McPhail).

"Wife critical of Crumpy.' The Press 22 July 2000: 18 (Robin Lee-Robinson "has welcomed a new play about the 'good keen man' but says she should have been approached for a realistic picture about his life ... Crump ... was more basic and scarred than people believed ...).

'Barry Crump play "not realistic".' Dominion 22 July 2000: 6 (with photo of Robin; quotes Nixon saying he had sent a copy of the script to Crump's fifth and last wife, Maggie, for her opinion - "She wasn't happy about the project and wrote me a letter asking me to stop. I asked her for reasons but she wouldn't contact me...").

'Crumpy.' Nelson Mail 13 Sept. 2000: 13 ("Until his death in 1996, Barry Crump was New Zealand's original 'good keen man'. Or, depending on your view, he was the country's 'nastiest bastard'. A play about him ... opens in Nelson ... tomorrow...").

Dan Dungan. 'Crump play achieves good balance'. Nelson Mail 15 Sept. 2000 (online at $<$ http://www.stuff.co.nz/inl/index/0.1008.376635al933.FF.html>: viewed 11.5.01): "The all-pervading spirit of Barry Crump's writing was of nostalgia, even in the very beginning. When his books first burst upon us nearly 40 years ago, they were most popular with adolescent boys already yearning for a life that was almost gone: deer culling and picaresque wandering in a rough, just-past-frontier country. Carl Nixon's play evokes the time well ... Crump's life was anything but simple and static. By carefully selecting certain incidents and ignoring others, a credible case could be made for a role model of masculine

Kōtare 4, no. 2 (2001), pp. 3-160. 
was anything but simple and static. By carefully selecting certain incidents and ignoring others, a credible case could be made for a role model of masculine self-sufficiency, an abuser of women and abandoner of children, a lovable wandering rascal with benevolent impulses, a homely philosopher, even a seeker after eternal truths. Here you will find hints of all these characters in one amalgam that achieves a satisfying balance...".

Mark Furness. 'Count Crumpy.' Press 28 Oct. 2000 Weekend: 4 (photo). Interview with actor Russell Smith, quoting him at length on Barry Crump whom he played in Carl Nixon's play ("He was a hardened bastard"; guesses that one in 50 Kiwis would have met Crump).

Fortune Theatre available online at (<http://www.fortunetheatre.co.nz/ crumpy/currprod.htm>: viewed 30.9.01): "... one of New Zealand's few true folk legends ... We saw him as the lovable, cheeky child made adult, never quite fitting in to the serious grown-up world and - knowing it to be overrated anyway - happy to trod [sic] his own twisty, adventurous path. With his happy-go-lucky, give-anything-a-go attitude, Crump's was the sort of resourceful independence we could admire. We didn't really want it for ourselves (it was a little too reckless and required too much hardship and courage), but we liked the idea of it. Still do. Today we feel differently about Barry. The 1999 television documentary on his life informed us of Crump's extreme violence at times ... This was unpalatable news of a former national icon. The Crumpy myth was dispelled forever ... He was a legend of his own making. As Colin Hogg wrote: 'He was a bastard and he was some sort of saint'.".

Ryan Keen. 'Crumpy takes the limelight.' The Southland Times 30 March 2001: 10 (" ... a warts and all fictional remembrance of the good keen man. ..."). Ryan Keen. 'Crump's complex life captured.' The Southland Times 2 April 2001: 9. ("... billed as fiction not documentary — although it was almost the reincarnation of Colin Hogg's biography ... And exactly what was fiction in the play was hard to discern. It was a concise, authentic, thoroughly salt-of-theearth romp through the life and times of Crump ... the highlight was the simply powerful flashback through a dying Crump's life ... a seamless dart from character to character. And then came the low-key soliloquy as Crump_headed off for the "ultimate wander, eh.".

Nigel Zega. 'Fortune Theatre. Teasing out truth of a good, keen man'. Otago Daily Times 19 April 2001 (online at <http://www.odt.co.nz/? issue=2001/19Apr2001 >): "Barry Crump must be chortling in his grave now a posthumous play is telling his story. Like him or loathe him, no-one can deny that the good keen man himself is as much a part of New Zealand folklore as black singlets and gumboots ...".

H303. Cate Brett. 'Saying no to violence. Merepeka Raukawa-Tait Abuse facts.' The Press 24 July 2000: 21: "... The new head of Women's Refuge talks ... about her shift from managing forestry blocks to protecting women and children. Barry

Kōtare 4, no. 2 (2001), pp. 3-160. 
do away with his wife-beating, child-abusing father. In the forced intimacy of Court 2 there are moments when the re-enactment of the thrashings the nation's favourite 'Good Keen Man' endured as a child makes the audience want to turn their faces, stop up their ears, step out for a breath of fresh air. All understandable reactions when confronted with the reality of domestic violence, but reactions which Merepeka Raukawa-Tait says New Zealanders have to start resisting if they want to bring an end to the grisly, mortifying toll of family violence in this country. Merepeka Raukawa-Tait... has more in common with the ghost of Barry Crump than her brown skin and executive livery might suggest. Like Crump, the 51-year-old is the product of a God-fearing rural community where beatings were as routine as Sunday roasts...".

H304. Gayle Smith, letter 'Barry Crump' The Southland Times 27 July 2000: 6 ("...I feel it is distasteful to use the deceased's name to benefit the Women's Refuge Appeal ... the bad in people is always highlighted when they are no longer around to defend themselves...").

H305. Allison Rudd. 'Sister city involvement brings its own rewards.' Otago Daily Times 19 Aug. 2000: "In the northern Japanese city of Otaru there is a city council employee who has a complete collection of Barry Crump books and whose hobby is collecting (and using) New Zealand colloquialisms. It is an unexpected result of Otaru's sister city relationship with Dunedin ...".

H306. Barry Hawkins. 'The ad fellows.' Evening Post 2 Sept. 2000: 27 (actors_in television ads, including Lloyd Scott in the Toyota series: "... He almost turned the job down when it came along in January 1982. 'I had a bit on at the time and had to juggle things' ... made him instantly recognisable, even now, years after they last appeared...").

H307. 'Rally promotes good keen fathers.' Waikato Times 4 Sept. 2000: 9 (Martin Crump addresses rally - "his father Barry was probably not the best example to use to promote a Father's Day rally ... a violent man and, while he bore him no ill-will, it was time to make a stand against family violence...").

H308. Tony Potter. 'Last of the good keen men was "the father Crump never had".' Sunday Star Times 24 Dec. 2000: 4. Obituary of Ted Rye, born 1906, "a legend in the bush ... an exceptional hunter ... the last of the pre-chopper men ... a great pig hunter ... Crump adored Ted and I think in many ways Ted was the father he never had ... a magnificent storyteller ... all of us used to sit there spellbound. Some of Ted's stories, fashioned and re-told, appear in the Crump books ... and he is definitely Jim Reed in A Good Keen Man..." (Jack Lasenby). For Rye, and Crump's use of his stories, see also Lasenby in Tribute pp.52-9.

H309. Musician Chris Moore at <http://www.guide-to-success.com/music/hack.html> (viewed 8.10.01) talking of the song 'Rise again' on his CD Hack (Christchurch: Cheshire Cat Promotions [2000]) quotes Crump: "'That's your best song boy, people are burning up, they need to be cooled down'. Crumpy told me about the

Kōtare 4, no. 2 (2001), pp. 3-160. 
Cheshire Cat Promotions [2000]) quotes Crump: "'That's your best song boy, people are burning up, they need to be cooled down'. Crumpy told me about the Bahai faith, about detachment, joy, unconditional love \& the need to 'quicken things up a bit'."

H310. Patrick Day. Voice and Vision, A History of Broadcasting in New Zealand. Volume 2. Auckland: Auckland University Press in association with Broadcasting History Unit, 200 1869402332. xii,456pp. Crump p.109 (acceptance on radio of the New Zealand accent): "A significant step came with the broadcasting of Barry Crump. Ian Cross, then working for Feltex, bought the rights for a reading of Crump's 1960 book, A Good Keen Man, on the Feltex-sponsored commercial radio programme, This is New Zealand. Crump's was 'a voice that only New Zealand could produce', but, in spite of its suitability for the book's tales of back-country hunting, it was judged unacceptable and Crump was not permitted to read his own work. But when Feltex purchased the rights to Crump's second book, Hang on a Minute Mate, the author was allowed to be its radio reader" (see also $\underline{\mathrm{H} 144}$ ).

H311. Marilyn Duckworth. Camping on the Faultline, A Memoir. Auckland: Vintage, 2000.1869414136.301pp. Crump: p.136 (Shadbolt letter: "The Crumps [Barry and Jean Watson] have gone south..."); p.143 (Crump at party with her sister Fleur Adcock), pp.144,145-7 (Fleur's marriage to Crump), pp.148-9, 153, 154 ("Fleur has left Barry..."), pp.155, 156 ("Hands Off!" telegram from Fleur), pp.162,177,190, 230, 238, 242.

Review: Sheila Alexander. Too much detail in Duckworth's memoir.' The Evening Standard 31 July 2000: 9 ("...The dirty laundry of many great New Zealand writers is aired as well as Duckworth's intimacies — Gee, Shadbolt, Duggan, Crump and Baxter ... I found the incestuous nature of the lives of the writers interesting - perhaps Marilyn shows up as a thinly disguised character in a Barry Crump or Maurice Gee novel...").

H312. George Johnston. The Hermit of Cemetery Island. Auckland: Reed, 2000. 0790007673. 164pp. Subtitle on cover: "Crump: The Untold Stories". From publisher's website, available online at <http://www.reed.co.nz/products.cfm? view=835\&catID=15> (viewed 30.9.01): "Once again Crumpy and his longsuffering mate Henry experience an unlikely string of adventures ... This is the second collection of stories from George Johnston, a longtime mate and hunting companion of Barry Crump. It continues the Crump tradition of rip-roaring yarns, recalling simpler days when life was an adventure to be exploited to the full.".

Review: Matthew Appleby. The Press 24 March 2001:17 ("The Barry Crump industry continues...").

H313. Colin Hogg. A Life in Loose Strides, The Story of Barry Crump. Auckland: Hodder Moa Beckett, C2000.1869588223. 200pp. Published Nov. 62000.

Kōtare 4, no. 2 (2001), pp. 3-160. 
Stories); pp.28-30: extract (p.13-15) from T become a deer culler' (from A Good Keen Man); pp.47-8: 'Sam' from Hang on a Minute Mate (further extracts from the book pp.61-3); and other extracts throughout from later Crump books, especially Life and Times of a Good Keen Man; p.33 prints a verse written by Crump on a hut wall, and pp.194-5 an extract from Crump's unpublished 'The Return of Sam Cash' (longer version, with slight differences, in Tribute pp.2025).

\section{Previews:}

Today Live TV1 17 Oct. 2000 (Hogg interviewed by Mary Lambie: New Zealand Television Archive).

Colin Hogg. 'The Crump contradiction.' Sunday Star Times 29 Oct. 2000: F 1: "'Even after his death, Barry Crump is working to keep his myth alive', writes Colin Hogg as his biography of the keenly flawed man is released. 'Barry Crump was never a hero of mine ... my heroes were rock bands ...' but interviewed ... 'he turned out to be even more colourful than autumn ... an ebullient and entertaining host, but there was a darkness behind all the light he was pouring out at me ... he seemed genuinely interested in other people ... where he got some of his raw material... Given his large natural charisma and eccentricity, Crump swiftly became almost inseparable from his books. A slavish media turned to him whenever there was a need for a good keen bloke kind of character. Crump could always be counted on to be himself in cinemascope ... I was hired to write a television documentary called Crump and I found out more about his dark side. That was when Crump came to me in a dream ... In the end I decided that Crump was a bastard and he was some sort of saint..."'.

An interview with Hogg about the book by Sarah Putt, 'Good Keen Men -Xtra talks to Barry Crump's Biographer Colin Hogg' Xtra : Entertainment : Books : Features Saturday, 23 December 2000, was formerly online (viewed from cache at www.google.com 12.2.01): "... Hogg doesn't spare his subject ... 'I'm fascinated by the theory that creative people who pour a lot of light in to their work are left with a lot of darkness in their souls. I think he's a prime example of that sort of thing,' he says. ... 'But he did have a fine ear for the language and an ability to spin a yarn on the page ... Hogg says he was more interested in "getting inside the bugger's head" than just cataloguing his adventures. Hogg believes that Crump was marked by an overwhelming charisma that infected everyone around him. ... Hogg met Crump only once, in a West Coast bar in the 1990s...".

\section{Reviews:}

Kingsley Field. 'Crumpy: boozer, basher and storyteller.' Waikato Times 18 Nov. 2000: 16 ("...there was another Crump that most of us knew nothing about, and it is this character that... Hogg has put under the microscope ... paints a stark, harsh and perhaps overly honest picture of Crump ...") Lloyd Scott. 'Crumpy's 
it is this character that... Hogg has put under the microscope ... paints a stark, harsh and perhaps overly honest picture of Crump ...") Lloyd Scott. 'Crumpy's charisma.' Dominion 2 Dec. 2000: 26 ("I have never read a Barry Crump book!... It made me frustrated, sad, shocked and caused_me to laugh out loud at times...")

David Hill. 'Laddish and lucid story of good keen man.' Weekend Herald 9-10 Dec. 2000:110 (" ...energetic, emphatic, perfunctory about the last years ..."). Michael Griffin. 'Tale of a complex man.' The Evening Standard 18 Dec. 2000: 9 (with photo; "a well-rounded portrait of a very complex character..."). Colin Larsen. Evening Post 29 Dec. 2000 ("fairly uninspiring and repetitive"). Mike Crean. 'The enigma of Crump.' The Press 6 Jan. 2001 ("The man emerges from this study as a fraud, though, especially later in life, one with some redeeming qualities. Hogg pulls no punches ... Book after book was churned out. The best were marked by humorously laconic story telling and believable presentation of anachronistic characters. The worst were awful. Over all, the literary merit was minimal. The biography ... is frank, perceptive, and revealing. Above all, it is interesting, not only because of the intriguing character of Crump, but because Hogg's direct style engages his readers and holds their attention....").

Stephen Jacquiery. 'Sympathetic tribute to a good keen man.' Otago Daily Times 22 March 2001 ("... As had been said many times, his life was the best story he ever wrote, and I found this biography of someone so familiar but equally unknown, a terrific read."). Julia Millen. New Zealand Books 47 (March 2001): $1,3$.

Alan Robson, online review at $<$ http://homepages.paradise.net.nz/triffid/wotired /holidays30.htm> (viewed 30.9.01): "... a less than illuminating book. The treatment is extremely shallow and Colin Hogg tells us nothing we didn't already know about Crumpy's life. He has simply taken common coin, woven a few ill-chosen words around it and presented it as a biography. It is intellectually shallow. Crump deserves much better than this. There is far more information and more insight in Crump's own autobiography...".

Cameron Officer, online review at $<$ http://entertainment.nzoom.com/books/story.html?story crump.inc (viewed 30.09.01) ("...will ... shatter some of the illusions and myths surrounding this back country folk hero").

H314. 'Bush raconteur has his own style.' The Press 1 March 2001 p.23 ("Terry Sleator, a travelling storyteller and balladeer from Opotiki ... recalls meeting Crumpy (Barry Crump) occasionally and being told 'there's no money in poetry'. He says it was the challenge he needed. He does a little bit of Crump, but he likes to have his own style ...").

H315. Kevin Ireland. 'North of the Bombay Hills, Kevin Ireland takes a literary look at Auckland and the North Shore.' Massey News April 2001 (online at

Kōtare 4, no. 2 (2001), pp. 3-160. 
turning point in the development of what we can now recognise to have been a growing literary awareness and sophistication. She came to live in Auckland after publishing The Story of a New Zealand River (1920), but its writing was heavily influenced by living and working in cities overseas. Grossman also had advanced political, social and moral concerns, and she too had travelled extensively, but the spirit of her writing remained sternly judgemental and Victorian. Mander injected into her writing the more complex attitudes and moods of a society in rapid change. The irony is that this social transformation would ultimately result in the Auckland writer, Barry Crump, describing his characters (from the 1960s to the 1980s) through a haze of rural nostalgia. The 'outback' had now become merely an 'outlandish' place — rough-romantic and anachronistic."

H316. Chris Else. 'Crump-like, but much less macho.' Evening Post 17 Aug. 2001: 7 (review of Tomorrow tastes better by Russell Haley — "the blurb implies a comparison with Barry Crump, and ... like Crump's Sam Cash, Harry has a comic vitality which plays against the New Zealand myth of the rugged, selfreliant individual living on his wits ... [but] Crump could never throw off the macho spirit of the stereotype ...").

H317. Amy Palmer. 'Manuscript Assessment.' The Publisher 70 (Aug. 2001): 3 (online at <http://www.bpanz.org.nz/bpanz4/pub70.pdf $>$ and at The Local Publishers Forum at <http://www.lpf.org.nz/archives/general/ms assess.htm>; both viewed 8.10.01). Report of a seminar by Ray Richards and others on assessing manuscripts. Crump's first manuscript is quoted as an example of "the importance of considering all manuscripts, even if they don't quite fit within the usual publishing house parameters".

H318. Vanya Lowry. From the Wisteria Bush. Auckland: Auckland University Press, 2001.1869402561. x,157pp. P.113, jobbing work done by her father, printer Bob Lowry, included business cards for Crump - "... When offered a manuscript by Crump, though, Bob thought it 'bullshit' and rejected it... The manuscript was $A$ Good Keen Man and would have made his fortune!" (He did, however, staple the manuscript for Crump: Sunday News 3 June 1973: 23).

H319. Brigid Magner. 'Trans-Tasman Impostures' in Philip Mead, ed. Australian Literary Studies in the 21st Century: Proceedings of the 2000 ASAL Conference held at the University of Tasmania, Hobart, 6-9 July 2000. [Hobart]: Association for the Study of Australian Literature, 2001. ix,226pp. Pp.174-81. Unseen: information from the author and from synopsis formerly at < http://hyperion.humsoc.utas.edu.au/efgj/english/asal2000/papers.htmb- (seen 30.8.01): "'Assimilations, Plagiarisms, and Masquerades in Trans-Tasman Fiction'. ... part of a larger project of investigating links between the neighbouring literary cultures of Australia and New Zealand ... will consider the common tendency of New Zealanders to disavow Australian cultural influence and the various dishonesties this may engender. To illustrate this trend, the Barry Crump/Dal Stivens plagiarism case may be invoked." (referring to 
<http://masseynews.massey.ac.nz/magazine/2001 Apr/stories/bombay hills.htm>: viewed 11.10.01): "... Jane Mander marvellously represents the turning point in the development of what we can now recognise to have been a growing literary awareness and sophistication. She came to live in Auckland after publishing The Story of a New Zealand River (1920), but its writing was heavily influenced by living and working in cities overseas. Grossman also had advanced political, social and moral concerns, and she too had travelled extensively, but the spirit of her writing remained sternly judgemental and Victorian. Mander injected into her writing the more complex attitudes and moods of a society in rapid change. The irony is that this social transformation would ultimately result in the Auckland writer, Barry Crump, describing his characters (from the 1960s to the 1980s) through a haze of rural nostalgia. The 'outback' had now become merely an 'outlandish' place — rough-romantic and anachronistic."

H316. Chris Else. 'Crump-like, but much less macho.' Evening Post 17 Aug. 2001: 7 (review of Tomorrow tastes better by Russell Haley — "the blurb implies a comparison with Barry Crump, and ... like Crump's Sam Cash, Harry has a comic vitality which plays against the New Zealand myth of the rugged, selfreliant individual living on his wits ... [but] Crump could never throw off the macho spirit of the stereotype ...").

H317. Amy Palmer. 'Manuscript Assessment.' The Publisher 70 (Aug. 2001): 3 (online at <http://www.bpanz.org.nz/bpanz4/pub70.pdf > and at The Local Publishers Forum at $<$ http://www.lpf.org.nz/archives/general/ms assess.htm>; both viewed 8.10.01). Report of a seminar by Ray Richards and others on assessing manuscripts. Crump's first manuscript is quoted as an example of "the importance of considering all manuscripts, even if they don't quite fit within the usual publishing house parameters".

H318. Vanya Lowry. From the Wisteria Bush. Auckland: Auckland University Press, 2001.1869402561. x,157pp. P.113, jobbing work done by her father, printer Bob Lowry, included business cards for Crump - "... When offered a manuscript by Crump, though, Bob thought it 'bullshit' and rejected it... The manuscript was $A$ Good Keen Man and would have made his fortune!" (He did, however, staple the manuscript for Crump: Sunday News 3 June 1973: 23).

H319. Brigid Magner. 'Trans-Tasman Impostures' in Philip Mead, ed. Australian Literary Studies in the 21st Century: Proceedings of the 2000 ASAL Conference held at the University of Tasmania, Hobart, 6-9 July 2000. [Hobart]: Association for the Study of Australian Literature, 2001. ix,226pp. Pp.174-81. Unseen: information from the author and from synopsis formerly at $<$ http://hyperion.humsoc.utas.edu.au/efgj/english/asal2000/papers.htmb — (seen 30.8.01): "'Assimilations, Plagiarisms, and Masquerades in Trans-Tasman Fiction'. ... part of a larger project of investigating links between the neighbouring literary cultures of Australia and New Zealand ... will consider the common tendency of New Zealanders to disavow Australian cultural influence 


\section{Manuscripts}

The only manuscript material by Crump held in a public collection that has been traced is that in the Alexander Turnbull Library, National Library of New Zealand, Wellington. They hold the following:

MS-Papers-1433: Typescript draft of A Good Keen Man dated July 1959 with manuscript additions and deletions (27 leaves);

MS-Papers-79-153-36 A H \& A W Reed Ltd: Records 1963-1970 Correspondence agreements and author files.

MS-Papers-6548 A H \& A W Reed Publishers Files relating to Barry Crump [1970]-1989 ("Two A H \& A W Reed author files relating to business dealings with Barry Crump, including correspondence, clippings, contracts, notes, royalty statements and other papers. Includes letters from Crump").

I have not seen material with references to Crump in the Dan Davin, Frank Sargeson, Phyllis Gant, or Alistair Campbell files.

\section{J. Publishers}

A.H. \& A.W. Reed. Ray Richards of Reeds accepted Crump's first book after it had been turned down by other publishers (see Bl; Ray Richards Tribute pp.735) and Crump remained with them to publish nine further books (ten counting Tzvo in One), the last "No Reference Intended" in mid-1971. Much of Reed's correspondence with and about Crump is held at the Alexander Turnbull Library (see Section I).

Crump Productions Ltd. Reeds declined to publish Bastards I Have Met (Crump "manoeuvred his way out of his obligations to Reed": Ray Richards Tribute p.74) and Crump published the book himself in late 1971 (B12; "my mate John Brown and I established our own publishing company", Sunday Nezvs 20 May 1973: 37), followed by Fred in 1972 and The Best of Crump in 1974.

C W Associates. After a break of several years Crump re-emerged with Shorty in 1980. He rejected offers from Reed (and apparently other publishers) and published the book himself with his friend "American-Rarotongan" Ric Welland (the book's illustrator) as "C W Associates", based in brother Bill Crump's garage. The manuscript and correspondence were typed by Welland's wife (B15; Life and Times pp.202-3; NZ Woman's Weekly 8 Dec. 1980: H87). Crump

Kōtare 4, no. 2 (2001), pp. 3-160. 
was quoted as saying that Crump receives "close to $20 \%$ of the retail price" of his books - Geoff Chappie. 'They did it'. Sunday Star 28 July 1991: C 1 (H161).

Moa Beckett (later Hodder Moa Beckett) published the subsequent Crump titles (B26-B32,1994-1999, apart from the poetry published by Hazard Press in 1996) and reprinted the earlier books. Moa Beckett, owned by its directors, Richard Beckett, John and Geoffrey Blackwell, was bought in 1994 by Hodder Headline ('British giant buys NZ book publisher' Evening Post 28 Dec. 1994), formed in 1993 from the merger of Headline with Hodder \& Stoughton and part of the W.H. Smith Group.

\section{K. Crump and the Cervical Smear Campaign}

In 1962 Crump assisted Dr Erich Geiringer in promoting cervical smear tests. Crump describes his time with Geiringer and their campaign - "we got some literature printed and flew to Dunedin..." — in Life and Times pp.119-21 and he talked about Geiringer "and how they set out on a campaign to inform people of the dangers of cervical cancer" on the Holmes show (TV1 9 July 1992: held by New Zealand Television Archive); see also Hogg Loose Strides p.88. Peter Kitchin's obituary of Geiringer, Evening Post 31 Aug. 1995, puts it: "...In 1962, with an unlikely colleague in Barry Crump, he attempted to have Dunedin's medical school students circulate pamphlets on [cervical smear testing] only to see them forbidden by university edict ...". Complaints were made to the police but the local police commander rated the pamphlets as not obscene and they were distributed (dropped into letterboxes) by arts faculty students.

In his periodical N.Z. Medical News 7 (29 May 1963), Geiringer prints a brief letter from "Barry Crump, North Queensland": "Dear Erich ... Why don't you publish details and results to date of the cervical smear campaign we did in Dunedin last year?". Geiringer replies that the number of smears done in Dunedin rose by $153 \%$... "figures on beer consumption in Dunedin during our stay are unfortunately not available. I hope to publish some of the interesting details of our campaign in a leaflet to the boys who helped us. Please leave a few crocodiles alive to help the Medical profession weep for the women who still needlessly die of cancer of the cervix every year".

I have not located a copy of the original pamphlet nor of the later leaflet (which may not have been produced).

Kōtare 4, no. 2 (2001), pp. 3-160. 


\section{Index}

This covers the titles of Crump's books, stories, articles and poems, together with selected authors of secondary material and selected topics and people mentioned in this bibliography. It is not of course intended as a representative overview of all aspects of Crump's life and times.

\section{Books}

(Main entries are in bold)

- The Adventures of Sam Cash: B2, B5, B18, G18

- Arty and the Fox: B26

- As the Saying Goes: B29, G29, $\underline{\mathrm{H} 228}$

- Back Down the Track: B31, G31

- Barry Crump: The Life and Times of a Good Keen Man: see The Life and Times of a Good Keen Man

- Barry Crump's Bedtime Yarns: $\underline{A 4}, \underline{A 7}, \underline{A 8}, \underline{A 9}, \underline{A 10}, A l l, \underline{A 15}, \underline{A 21}, \underline{B} 4$, B9, B17, B22, G21

- A Barry Crump Collection: B10, B15, B16, B20

- Bastards I Have Met: B12, B13, B14, G12, H57, H58, H61,

- Bedtime Yarns: see Barry Crump's Bedtime Yarns

- The Best of Barry Crump: see The Best of Crump

- The Best of Crump: B1, B2, B4, $\underline{B}$, B6, B8, B9, B10, B13, B14

- Bullock Creek: B23, G23, $\underline{\mathrm{H} 149}, \underline{\mathrm{H} 135}, \underline{\mathrm{H} 143}, \underline{\mathrm{H} 149}$

- Bush Telegraph: $\underline{\mathbf{C 6}}$

- Crocodile Country: see Gulf

- Crumpy's Campfire Companion: $\underline{A 33}-\underline{A 37}, \underline{A 39}-\mathrm{A40}, \underline{B 28}, \underline{F 13}, \underline{F 15}, \underline{F 16}$, G28

- Forty Yarns and a Song: $\underline{A 16}-\underline{A 24}, \underline{A 26}-\underline{A 32}, B I, \underline{B} 2, \underline{B 27}$

- Fred: B12, B13, $\underline{\mathrm{H} 65}, \underline{\mathrm{H} 66}$

- Gold and Greenstone: B25, G25

- A Good Keen Girl: B10, B20, G8, G10, H48, 4ㅇ, H54

- A Good Keen Man: A1, A2, A12, B1, B27, G1, $\underline{H 11}, \underline{H 14}, \underline{H 15}, \underline{H 88}$, $\underline{\mathrm{H} 99}, \underline{\mathrm{H} 144}, \underline{\mathrm{H} 189}, \underline{\mathrm{H} 193}, \underline{\mathrm{H} 199}, \underline{\mathrm{H} 212}, \underline{\mathrm{H} 235}, \underline{\mathrm{H} 236}, \underline{\mathrm{H} 239}, \underline{\mathrm{H} 242}, \underline{\mathrm{H} 272}$, $\underline{\mathrm{H} 277}, \underline{\mathrm{F} 290}, \underline{\mathrm{H} 295}, \underline{\mathrm{H} 308}, \underline{\mathrm{H} 310}$

- Gulf: $\underline{\mathrm{A} 5}, \underline{\mathrm{B} 6}, \underline{\mathrm{B} 20}, \underline{\mathrm{G}} 6, \underline{\mathrm{H} 44}, \underline{\mathrm{H} 125}$. See also Australia.

- Hang on a Minute Mate: $\underline{B 2}, \underline{B 18}, \underline{D 2}, \underline{\mathrm{D} 3}, \underline{\mathrm{G} 2}, \underline{\mathrm{H} 15}, \underline{\mathrm{H} 56}, \underline{\mathrm{H} 78}, \underline{\mathrm{H} 83}, \underline{\mathrm{H} 87}$, $\underline{\mathrm{H} 89}, \underline{\mathrm{H} 100}, \underline{\mathrm{H} 153}, \underline{\mathrm{H} 189}$

- Humble Abodes: B21

Kōtare 4, no. 2 (2001), pp. 3-160. 


\section{Index}

This covers the titles of Crump's books, stories, articles and poems, together with selected authors of secondary material and selected topics and people mentioned in this bibliography. It is not of course intended as a representative overview of all aspects of Crump's life and times.

\section{Books}

(Main entries are in bold)

- The Adventures of Sam Cash: B2, B5, B18, G18

- Arty and the Fox: B26

- As the Saying Goes: B29, G29, $\underline{\text { H228 }}$

- Back Down the Track: B31, G31

- Barry Crump: The Life and Times of a Good Keen Man: see The Life and Times of a Good Keen Man

- Barry Crump's Bedtime Yarns: $\underline{A 4}, \underline{A 7}, \underline{A 8}, \underline{A 9}, \underline{A 10}, A l l, \underline{A 15}, \underline{A 21}, \underline{B} 4$, B9, B17, B22, G21

- A Barry Crump Collection: B10, B15, B16, B20

- Bastards I Have Met: B12, B13, B14, G12, H57, H58, H61,

- Bedtime Yarns: see Barry Crump's Bedtime Yarns

- The Best of Barry Crump: see The Best of Crump

- The Best of Crump: B1, B2, B4, $\underline{B}$, B6, B8, B9, B10, B13, B14

- Bullock Creek: B23, G23, $\underline{\mathrm{H} 149}, \underline{\mathrm{H} 135}, \underline{\mathrm{H} 143}, \underline{\mathrm{H} 149}$

- Bush Telegraph: $\underline{\mathbf{C 6}}$

- Crocodile Country: see Gulf

- Crumpy's Campfire Companion: $\underline{A 33}-\underline{A 37}, \underline{A 39}-\mathrm{A40}, \underline{B 28}, \underline{F 13}, \underline{F 15}, \underline{F 16}$, G28

- Forty Yarns and a Song: $\underline{A} 16-\underline{A} 24, \underline{A 26}-\underline{A} 2, B, B 2, \underline{B} 27$

- Fred: B12, B13, H65,

- Gold and Greenstone: B25, G25

- A Good Keen Girl: B10, B20, G8, G10, H48, 4ㅇ, H54

- A Good Keen Man: A1, A2, A12, B1, B27, G1, $\underline{H 11}, \underline{H 14}, \underline{H 15}, \underline{H 88}$, $\underline{\mathrm{H} 99}, \underline{\mathrm{H} 144}, \underline{\mathrm{H} 189}, \underline{\mathrm{H} 193}, \underline{\mathrm{H} 199}, \underline{\mathrm{H} 212}, \underline{\mathrm{H} 235}, \underline{\mathrm{H} 236}, \underline{\mathrm{H} 239}, \underline{\mathrm{H} 242}, \underline{\mathrm{H} 272}$, $\underline{\mathrm{H} 277}, \underline{\mathrm{F} 290}, \underline{\mathrm{H} 295}, \underline{\mathrm{H} 308}, \underline{\mathrm{H} 310}$

- Gulf: $\underline{\mathrm{A} 5}, \underline{\mathrm{B} 6}, \underline{\mathrm{B} 20}, \underline{\mathrm{G}} 6, \underline{\mathrm{H} 44}, \underline{\mathrm{H} 125}$. See also Australia.

- Hang on a Minute Mate: $\underline{B 2}, \underline{B 18}, \underline{D 2}, \underline{\mathrm{D} 3}, \underline{\mathrm{G} 2}, \underline{\mathrm{H} 15}, \underline{\mathrm{H} 56}, \underline{\mathrm{H} 78}, \underline{\mathrm{H} 83}, \underline{\mathrm{H} 87}$, $\underline{\mathrm{H} 89}, \underline{\mathrm{H} 100}, \underline{\mathrm{H} 153}, \underline{\mathrm{H} 189}$

- Humble Abodes: B21

Kōtare 4, no. 2 (2001), pp. 3-160. 
- Song of a Drifter and Other Ballads: B30, G30

- Warm Beer and Other Stories: $\underline{A 3}, \underline{A 4}, \underline{A 7}, \underline{A 8}, \underline{A 9}, \underline{A 10}, \underline{A 11}, \underline{B 9}, \underline{B 22}$, $\underline{\mathrm{H} 140}$

- Wild Pork and Watercress: B19, G19, $\underline{\mathrm{H} 32}, \underline{\mathrm{H} 108}, \underline{\mathrm{H} 126}-\underline{\mathrm{H} 129}, \underline{\mathrm{H} 135}$, $\underline{\mathrm{H} 137}, \underline{\mathrm{H} 276}$

\section{Stories \& Articles in Periodicals}

- Back when I was a boy: $\underline{\text { A29 }}$

- Basil, nannies and the kids: $\underline{A 28}$

- Bill goat: $\underline{A 6}$,

- A bit of a break: $\underline{\text { A4 }}$

- A bit of bad luck: $\underline{\text { A31 }}$

- Bottom of the barrel: $\underline{A 38}$

- Clarry Anything: A12

- A clean swap: $\underline{\text { A5 }}$

- Down on the farm: $\underline{A 34}$

- Early reading: $\underline{A} 13$

- Fear of heights: A33

- A good keen man: Al, $\underline{\mathrm{H} 236}, \underline{\mathrm{H} 272}$

- Hard yakker: A37

- Horseplay: A9

- Jam packed: $\underline{\text { A23 }}$

- Lawful excuse: $\underline{A} 10, \underline{C 5}, \underline{D 1}, \underline{\mathrm{H} 118}$

- A long haul: $\underline{A 36}$

- The man from the bottom of the barrel: $\underline{C 9}$

- The man time forgot: $\underline{\mathrm{A} 18}$

- Mr Thorpe: $\underline{\mathrm{A} 2}$

- More golf: $\underline{\mathrm{A} 14}$

- Night of The BB and BB: $\underline{A 25}$

- No trouble.... A39

- The odd hitch: A11

- On a dead cert: $\underline{\text { A26 }}$

- One in the bull's eye: $\underline{A 20}$

- Overheard in the pub: $\underline{A 8}$

- Post taste: $\underline{\mathrm{A} 16}$

- A real Kiwi joker: $\underline{A} 27$

- Safari in Ghuznee Street: A24

- Snakes alive: $\underline{\mathrm{A} 30}$ 
- The Pungapeople of Ninety Mile Beach: $\underline{B} 32$

- Song of a Drifter: B24, B27, B30.

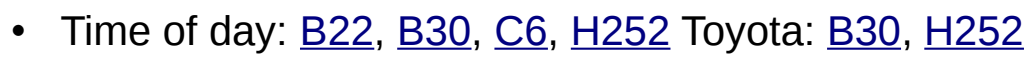

\section{Books Printing Material by Crump}

Excludes anthologies reprinting extracts; includes books quoting Crump

- Barry Crump: A Tribute to Crumpy: $\underline{\mathrm{H} 235}, \underline{\mathrm{H} 252}$

- The Book of Friends: $\underline{\mathrm{C}}$

- Bush Telegraph: $\underline{\mathrm{C} 6}$

- Bushwoman: $\underline{\mathrm{C} 8}$

- Face to Face: $\underline{\mathrm{C} 1}$

- Household Gods: $\underline{\mathrm{C} 10}$

- The Best Job Ever: $\underline{\mathrm{H} 190}$

- A Lawful Excuse. Shooting Script: $\underline{\text { 5 }}$

- A Life in Loose Strides: $\underline{\mathrm{H} 315}$

- Magic Kiwis: $\underline{\mathrm{H} 165}$

- New Zealand Wit and Wisdom: $\underline{\text { C11 }}$

- Open Country: $\underline{\mathrm{C} 3}$

- Prayers for New Zealanders: $\underline{\mathrm{C} 4}$

- Stag Party: $\underline{\mathrm{C}}$

- Tall Tales and True: $\underline{\mathrm{A38}}, \underline{\mathrm{C} 9}$

\section{Periodicals Printing Material by Crump}

- Auckland Star: B19

- Book Counsel: $\underline{\mathrm{A} 13}$

- Education: $\underline{\mathrm{A} 13}$

- Man: $\underline{\mathrm{A} 3}$

- The Maorilander: $\underline{\mathrm{H} 62}$

- Mate: $\underline{A 1}, \underline{A 2}, \underline{A 11}$

- NZ Golf Magazine: A14

- NZ Listener: $\underline{A 4}, \underline{A 6}, \underline{A 7}, \underline{A 8}$,

- NZ School Journal: A12

- NZ Weekly News: $\underline{A 5}, \underline{A 9}, \underline{A 10}$,

- Otago University Review: $\underline{A}$

- Southern Skies: $\underline{A 15}-\underline{A 40}, \underline{B} 17$

- Sunday Star: B19

- Sunday News: B12, B13, $\underline{\mathrm{H} 57}, \underline{\mathrm{H} 58}, \underline{\mathrm{H} 67}, \underline{\mathrm{H} 68}$

Kōtare 4, no. 2 (2001), pp. 3-160. 


\section{Illustrators}

- Adams, Geoff: $\underline{A 3}$

- Baker, Howard: B13, B14

- Ball, Murray: B17, G17, $\mathrm{H} 202$

- Bradley, Roger: B13, B14

- Brockie, Bob: $\underline{\mathrm{H} 43}$

- Cash, Ivan: $\underline{\mathrm{H} 26}$

- Crawley, John: B8, B14

- Ellison, Anthony: A17-A36, A38-A40

- Emmerson, K.: $\underline{\mathrm{A} 15}$, B17, B22, B23

- Evans, Malcolm: B19

- Grimsdale, M.: All

- Hart, Roger: $\underline{A 6}, \underline{A 7}, \underline{B 7}, \underline{B 14}$

- Jenks, W.: A4

- Kent, Dennis: B30

- Kirk, Graham: B12

- McWilliams, Tom: A12

- Mahony, Will: B6, B14

- Morgan: $\underline{A 5}, \underline{A 9}$

- Poulton, Linda: B16, B22.

- Stones, Tony \& Cushla: B10, B11, B14, B22

- Tapper, Garth: B12, B14

- Trembeth, Pat: B26, B30

- Turner, Dennis: B1, B2, B3, B4, B5, B14, B16, B18, B22, B25, H164

- Ware, Natalie: B32

- Welland, Ric: B15, $\underline{\mathrm{H} 87}$

\section{People}

(A select list of people mentioned or whose books or articles are listed)

- Adcock, F.: B2 $, \underline{\mathrm{H} 19}, \underline{\mathrm{H} 20}, \underline{\mathrm{H} 28}, \underline{\mathrm{H} 151}, \underline{\mathrm{H} 137}, \underline{\mathrm{H} 210}, \underline{\mathrm{H} 258}, \underline{\mathrm{H} 287}, \underline{\mathrm{H} 321}$

- Baxter, J.K.: A3, G4, G5

- Crump, Harry: $\underline{\mathrm{H} 67}, \underline{\mathrm{H} 112}$

- Crump, Maggie: $\underline{\mathrm{H} 178}, \underline{\mathrm{H} 247}, \underline{\mathrm{H} 252}, \underline{\mathrm{H} 265}, \underline{\mathrm{H} 302}$

- Crump, Martin: $\underline{\mathrm{H} 224}, \underline{\mathrm{H} 226}, \underline{\mathrm{H} 237}, \underline{\mathrm{H} 243}, \underline{\mathrm{H} 252}, \underline{\mathrm{H} 278}, \underline{\mathrm{H} 288}, \underline{\mathrm{H} 307}$

- Crump, Robyn (Robin Lee Robinson): B15, B16, B17, 6ㅡ, ㅂ8, ㅂ5, $\underline{\mathrm{H} 87}, \underline{\mathrm{H} 130}, \underline{\mathrm{H} 143}, \underline{\mathrm{H} 248}, \underline{\mathrm{H} 252}, \underline{\mathrm{H} 270}$

- Crump, Sigrid: $\mathrm{C} 8$ 


\section{Illustrators}

- Adams, Geoff: $\underline{A 3}$

- Baker, Howard: B13, B14

- Ball, Murray: B17, G17, $\underline{\mathrm{H} 202}$

- Bradley, Roger: B13, B14

- Brockie, Bob: $\underline{\mathrm{H} 43}$

- Cash, Ivan: $\underline{\mathrm{H} 26}$

- Crawley, John: B8, B14

- Ellison, Anthony: A17-A36, A38-A40

- Emmerson, K.: A15, B17, B22, B23

- Evans, Malcolm: B19

- Grimsdale, M.: All

- Hart, Roger: $\underline{A 6}, \underline{A 7}, \underline{B 7}, \underline{B 14}$

- Jenks, W.: A4

- Kent, Dennis: B30

- Kirk, Graham: B12

- McWilliams, Tom: A12

- Mahony, Will: B6, B14

- Morgan: A5, A9

- Poulton, Linda: B16, B22.

- Stones, Tony \& Cushla: B10, B11, B14, B22

- Tapper, Garth: B12, B14

- Trembeth, Pat: B26, B30

- Turner, Dennis: B1, B2, B3, B4, B5, B14, B16, B18, B22, B25, H164

- Ware, Natalie: B32

- Welland, Ric: B15, $\underline{\mathrm{H} 87}$

\section{People}

(A select list of people mentioned or whose books or articles are listed)

- Adcock, F.: $\underline{B 2}, \underline{\mathrm{H} 19}, \underline{\mathrm{H} 20}, \underline{\mathrm{H} 28}, \underline{\mathrm{H} 151}, \underline{\mathrm{H} 137}, \underline{\mathrm{H} 210}, \underline{\mathrm{H} 258}, \underline{\mathrm{H} 287}, \underline{\mathrm{H} 321}$

- Baxter, J.K.: A3, G4, G5

- Crump, Harry: $\underline{\mathrm{H} 67}, \underline{\mathrm{H} 112}$

- Crump, Maggie: $\underline{\mathrm{H} 178}, \underline{\mathrm{H} 247}, \underline{\mathrm{H} 252}, \underline{\mathrm{H} 265}, \underline{\mathrm{H} 302}$

- Crump, Martin: $\underline{\mathrm{H} 224}, \underline{\mathrm{H} 226}, \underline{\mathrm{H} 237}, \underline{\mathrm{H} 243}, \underline{\mathrm{H} 252}, \underline{\mathrm{H} 278}, \underline{\mathrm{H} 288}, \underline{\mathrm{H} 307}$

- Crump, Robyn (Robin Lee Robinson): B15, B16, B17, 6ㅡ, ㅂ8, ㅂ5, $\underline{\mathrm{H} 87}, \underline{\mathrm{H} 130}, \underline{\mathrm{H} 143}, \underline{\mathrm{H} 248}, \underline{\mathrm{H} 252}, \underline{\mathrm{H} 270}$

- Crump, Sigrid: $\underline{\mathrm{C} 8}$ 
- Ireland, K.: $\underline{\mathrm{A} 1}, \mathrm{BI}, \underline{\mathrm{B} 30}, \underline{\mathrm{C} 1}, \underline{\mathrm{H} 137}, \underline{\mathrm{H} 153}, \underline{\mathrm{H} 199}, \underline{\mathrm{H} 233}, \underline{\mathrm{H} 236}, \underline{\mathrm{H} 237}$, $\underline{\mathrm{H} 245}, \underline{\mathrm{H} 252}, \underline{\mathrm{H} 272}, \underline{\mathrm{H} 315}, \underline{\mathrm{H} 321}$

- Johnston, G.: $\underline{F 14}, \underline{H 46}, \underline{H 58}, \underline{H 246}, \underline{H 252}, \underline{H 293}, \underline{H} 312$

- Kearns, B.: BI, $\underline{\mathrm{H} 14}, \underline{\mathrm{H} 144}, \underline{\mathrm{H} 239}, \underline{\mathrm{H} 242}, \underline{\mathrm{H} 310}$

- Lasenby, J.: A12, B7, $\underline{\mathrm{H} 252}, \underline{\mathrm{H} 279}, \underline{\mathrm{H} 308}$

- Lowe, Bob: $\underline{\mathrm{C}} 4, \underline{\mathrm{H} 70}, \underline{\mathrm{H} 73}$

- Lowry, Bob: $\underline{\mathrm{H} 258}, \underline{\mathrm{H} 31}$

- McCarten, A.: D3

- Nixon, Carl: $\mathrm{H} 302$

- O'Shea, J.: F1, H34, $\underline{\mathrm{H} 35}, \underline{\mathrm{H} 133}, \underline{\mathrm{H} 298}$

- Richards, R.: Bl, B2, B3, B4 $, \underline{\mathrm{H} 23}, \underline{\mathrm{H} 212}, \underline{\mathrm{H} 235}, \underline{\mathrm{H} 252}, \underline{\mathrm{H} 317}$

- Rye, Ted: $\underline{\mathrm{H} 308}$

- Sargeson, F.: $\underline{\mathrm{H} 53}, \underline{\mathrm{H} 207}$

- Scott, L.: E3, F16, $\underline{\mathrm{H} 103}, \underline{\mathrm{H} 107}, \underline{\mathrm{H} 113}, \underline{\mathrm{H} 114}, \underline{\mathrm{H} 191}, \underline{\mathrm{H} 252}, \underline{\mathrm{H} 268}, \underline{\mathrm{H} 286}$, $\underline{\mathrm{H} 306}, \underline{\mathrm{H} 313}$

- Shadbolt, M.: $\underline{\mathrm{H} 35}, \underline{\mathrm{H} 106}, \underline{\mathrm{H} 258}, \underline{\mathrm{H} 287}$

- Stivens, D.: A8

- Tuwhare, H.: $\underline{\mathrm{H} 69}$

-Watson, J.: $\underline{B} 3, \underline{B 5}, \underline{H 26}, \underline{H 34}, \underline{H 67}, \underline{H 71}, \underline{H 133}, \underline{H 137}, \underline{H 252}, \underline{H 287}$, $\underline{\mathrm{H} 298}$

\section{Publishers of Crump's Books}

(see also Section J)

- Barry Crump Associates: BI, B44-B6 $, \underline{B 12}, \underline{B 16}, \underline{B 22}, \underline{B 23}, \underline{B} 24, \underline{B 25}, \underline{H 161}$

- Beckett: BI, B4-5, B7, B12, B18, B19

- Bodley Head: B2

- Crump Productions Ltd.: B12-B14

- C \& C Associates: B16

- CW Associates: B15

- Firstlight Productions: $\underline{B} 1, \underline{\mathrm{C}}$

- Gold Star Publications: B12

- Hazard Press: B30

- Hodder Moa Beckett: BI-2, B4-B32, $\underline{\mathrm{H} 252}, \underline{\mathrm{H} 313}$

- Moa Beckett: B4, B5, B25, B26, B27

- Reed: B1-B11, $\underline{\mathrm{H} 40}, \underline{\mathrm{H} 44}, \underline{\mathrm{H} 162}$ (see also Ray Richards).

- SeTo Publishing: B21

- Tri-Ocean Books: $\underline{\text { B6 }}$ 